\title{
Geology and Iron Deposits \\ of the Western Serra do \\ Curral, Minas Gerais, Brazil
}

GEOLOGICAL SURVEY PROFESSIONAL PAPER 341-G

Prepared in cooperation with the Departamento Nacional da Produção Mineral of Brazil under the auspices of the Agency for International Development of the United States Department of State

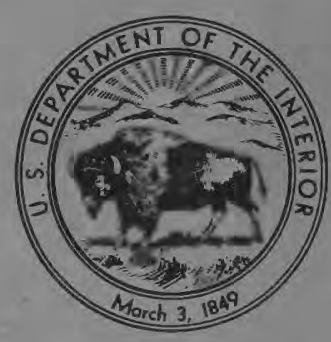




\section{Geology and Iron Deposits \\ of the Western Serra do \\ Curral, Minas Gerais, Brazil}

By GEORGE C. SIMMONS

GEOLOGY AND MINERAL RESOURCES OF PARTS OF MINAS GERAIS, BRAZIL

GEOLOGICAL SURVEY PROFESSIONAL PAPER 341-G

Prepared in cooperation with the Departamento

Nacional da Produção Mineral of Brazil under the auspices of the Agency for International Development of the United States Department of State

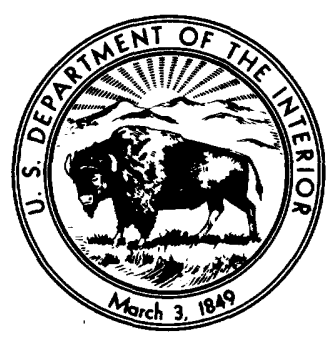

A study of Precambrian rocks and associated hematite ores in the Brazilian shield

UNITED STATES GOVERNMENT PRINTING OFFICE, WASHINGTON : 1968 


\title{
UNITED STATES DEPARTMENT OF THE INTERIOR
}

\section{STEWART L. UDALL, Secretary}

\section{GEOLOGIGAL SURVEY}

\author{
William T. Pecora, Director
}

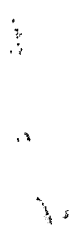

$\because x_{i}$

For sale by the Superintendent of Documents, U.S. Government Printing Office, Washington. D.C.

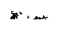




\section{CONTENTS}

Abstract

Introduction .................

General background......

Coordinate system.

Geography

Previous investigations

Present investigation. . . .

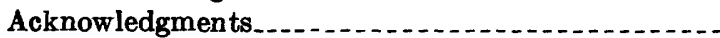

Geologic setting

Quadrilátero Ferriffero...........................

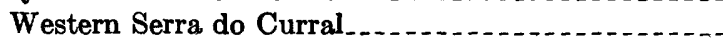

Stratigraphy.

Rio das Velhas Series

Nova Lima Group. Schists and phyllites...... Ferruginous phyllite and iron-formation Other rocks. . .

Minas Series.

Caraça Group. Moeda Formation Batatal Formation

Itabira Group. Cauê Itabirite.

Cauê-Gandarela contact. ........

Gandarela Formation

Piracicaba Group.

Cercadinho Formation

Fêcho do Funil Formation. . . . . . . . .

Taboões Quartzite.

Barreiro Formation

Sabará Formation.

Cenozoic deposits......

Igneous rocks

Granitic rocks...

Itabirito(?) Gneiss

Group IV gneiss in the Itaúna uplands......

Souza Noschese Gneiss. ................

Group III gneiss in the Igarapé pediments....

Dike rocks.....

Structure.

Bonfim gneiss dome

Gneiss dome north of the Serra do Curral.

\begin{tabular}{|c|c|c|}
\hline Page & & Page \\
\hline G1 & Structure-Continued & \\
\hline $\mathbf{2}$ & Folds in the Nova Lima Group & G27 \\
\hline 2 & Piedade syncline. & 28 \\
\hline 2 & North limb of the Piedade syncline & 29 \\
\hline 2 & Metamorphism & 29 \\
\hline 5 & Regional metamorphism & 29 \\
\hline 5 & Contact metamorphism & 30 \\
\hline 5 & Quartzite & 30 \\
\hline 5 & Pelitic rocks & 30 \\
\hline 5 & Hematite schist & 31 \\
\hline 6 & Iron deposits. & 31 \\
\hline 7 & High-grade replacement deposits and ores. & 31 \\
\hline 9 & Detrital deposits and ores & 34 \\
\hline 9 & Residual deposits, ores, and potential ores........ & 34 \\
\hline 9 & Reserves_-1. & 35 \\
\hline 10 & Brumadinho àrea & 37 \\
\hline 11 & C6́rrego do Feijâö. & 37 \\
\hline 11 & Serradão-1- & 40 \\
\hline 11 & Pico dos Tres Irmãos & 42 \\
\hline 11 & Laranjeiras & 42 \\
\hline 13 & Bocaina & 42 \\
\hline 13 & Tijuco canga deposit & 43 \\
\hline 14 & Tijuco rolado & 43 \\
\hline 16 & Serra do Fêcho do Funil & 45 \\
\hline 16 & Altino Andrade & 45 \\
\hline 16 & Souza Noschese & 45 \\
\hline 17 & Candú area. & 46 \\
\hline 18 & Serra das Farofas. & 48 \\
\hline 19 & Pau de Vinho & 48 \\
\hline 20 & West End area & 50 \\
\hline 21 & Serra da Mantiqueira-Serra do Barreiro....... & 50 \\
\hline 22 & Serra do Itatiaia & $\mathbf{5 0}$ \\
\hline 22 & Serra Azul & 51 \\
\hline 22 & Other mineral resources & 51 \\
\hline 23 & Manganese & 51 \\
\hline 25 & Manoel Sampaio prospect & 51 \\
\hline 25 & Serra Azul prospects & 51 \\
\hline 26 & Gold & 51 \\
\hline 26 & - & 52 \\
\hline 27 & 县 & 52 \\
\hline 27 & terature cited...... & 52 \\
\hline 27 & Index & 55 \\
\hline
\end{tabular}

\section{ILLUSTRATIONS}

[Plates are in pocket]

Plate 1. Geologic map and sections of the south half of the Fêcho do Funil and the north half of the Brumadinho quadrangles, Minas Gerais, Brazil.

2. Geologic map of the south half of the Igarape and the north half of the Sousas quadrangles, Minas Gerais, Brazil.

3. Geologic map of the south half of the Serra Azul and the north half of the Itatiaiuçu quadrangles, Minas Gerais, Brazil.

4. Geologic map of the Bocaina area, south half of the Fêcho do Funil quadrangle, Minas Gerais, Brazil.

5. Geologic map and section of the Candú area, south half of the Fêcho do Funil quadrangle, Minas Gerais, Brazil. 
Figure 1. Index map of the Quadrilatero Ferrífero.

2. Map showing physiographic divisions (informal) of the western Serra do Curral

3. Generalized geologic map of the western Serra do Curral

4. Map showing principal structures and general rock distribution in the western Serra do Curral . 5-9. Photographs:

5. Iron-formation of the Nova Lima Group.

6. Cauê Itabirite

7. Itabirito(?) Gneiss intruded by Souza Noschese Gneiss.

8. High-grade compact hematite

9. Hematite replacement of itabirite.

10. Geologic map of the Corrego do Feijão iron deposit.

11. Geologic map of the Tijuco rolado deposit

12. Photograph of the Tijuco rolado deposit

13. Photograph of Batatal Formation and Cauê Itabirite

14. Geologic map of the Pau de Vinho mine.

\section{TABLES}

TABLE 1. Stratigraphic column for Precambrian rocks in the western Serra do Curral

2. Chemical analyses of stratified rocks in the western Serra do Curral

3. Thickness and percentage of lithologic types in a section of the Itabira Group measured in the Rio Paraopeba water gap through the Serra do Curral.

4. Chemical analyses of itabirite from the Cauê Itabirite in the western Serra do Curral

5. Correlation of the granitic rocks of the western Serra do Curral with age groups, type granitic rocks, and granitic rock ages in the Quadrilatero Ferrifero.

6. Analyses of granitic rocks from the Brumadinho area compared with average analyses of Group II and Group III granitic rocks of the Quadrilatero Ferrifero.

7. Indicated and inferred iron reserves of the western Sera

8. Indicated and inferred iron reserves in the western Serra do Curral by deposit and mine area

9. Potential iron resources in the western Serra do Curra

10. Analyses of successive intervals sampled in Córrego do Feijão exploration drifts

11. Western Serra do Curral iron ore analyses. 


\title{
GEOLOGY AND MINERAL RESOURCES OF PARTS OF MINAS GERAIS, BRAZIL
}

\section{GEOLOGY AND IRON DEPOSITS OF THE WESTERN SERRA DO GURRAL, MINAS GERAIS, BRAZIL}

\author{
By George C. Simmons
}

\begin{abstract}
Brazil's famous iron region, the Quadrilatero Ferrifero, covers almost 7,000 square kilometers in the south-central part of the State of Minas Gerais. Folded Precambrian itabirite, a low-grade metamorphic, oxide-facies iron-formation consisting of alternating hematite- and quartz-rich laminae, is present throughout this region. The itabirite contains high-grade hematite ores and is the source of other iron deposits. The western Serra do Curral covers more than 500 square kilometers in the Serra Azul, Igarapé, Fêcho do Funil, Itatiaiuçu, Sousas, and Brumadinho quadrangles and forms the western protuberance of the Quadrilatero Ferrffero. This area includes a syncline limb that contains the conspicuous itabirite formation and high-grade and other iron deposits.
\end{abstract}

Two series of rocks having an aggregate thickness of 2,300 meters underlie the western Serra do Curral. The lower series, the Rio das Velhas Series, though elsewhere represented by three groups, here consists only of rocks provisionally assigned to the Nova Lima Group. This group is composed of chlorite and muscovite schist and phyllite, ferruginous phyllite, iron-formation, and minor quartzite and conglomerate. The upper series, the Minas Series, comprises three groups containing nine formations, which from lowest to uppermost are: Caraça Group (Moeda Formation, Batatal Formation); Itabira Group (Cauê Itabirite, Gandarela Formation); Piracicaba Group (Cercadinho Formation, Fêcho do Funil Formation, Taboões Quartzite, Barreiro Formation, Sabará Formation).

The Caraça Group contains only clastic metasedimentary rocks, including arenaceous phyllite and quartzite of the Moeda Formation and phyllite of the Batatal Formation. The Itabira Group contains the principal chemical sedimentary rocks in the Minas Series, including varieties of itabirite and dolomite, and also contains phyllite. Most of the itabirite is in the Cauê Itabirite, and most of the dolomite and phyllite is in the Gandarela Formation. The Piracicaba Group consists of (1) the Cercadinho Formation, containing ferruginous quartzite, conglomerate, phyllite, dolomitic phyllite, and argillaceous dolomite; (2) the Fêcho do Funil Formation, containing dolomitic phyllite and siltstone, and silty argillaceous dolomite; (3) the Taboões Quartzite, a relatively pure massive very fine grained friable quartzite; (4) the Barreiro Formation, composed of phyllite, most of which is carbonaceous; and (5) the Sabara Formation, which almost everywhere is weathered to saprolite-probably derived largely from tuff, graywacke, and phyllite-but which also contains quartzite and conglomerate.

Five principal petrologic types of granitic rocks are recognized in the Quadrilatero Ferrffero. The rocks have been assigned to age groups ranging from about 500 to 2,600 million years on the basis of potassium-argon age determinations of biotite and rubidium-strontium determinations of feldspars. From oldest to youngest, the groups are Group I, Group II, Group III granitic facies, Group IV, and Group III gneissic facies.

Three of these divisions-Group II, Group IV, and Group III gneissic facies-are recognized in the western Serra do Curral region. Group II is represented by Itabirito(?) Gneiss, a gray medium- to coarse-grained well-foliated granodiorite gneiss having alternating biotite-rich and felsic layers. Group IV is represented by a light-gray medium-grained poorly foliated granodiorite gneiss. Group III gneissic facies is represented by the Souza Noschese Gneiss and by a gneiss correlative with it. The Souza Noschese Gneiss is a light-gray fine- to medium-grained poorly foliated granite gneiss; the correlative gneiss resembles the Souza Noschese Gneiss but is very poorly exposed and, hence, was not studied in detail.

Diabase dikes, plugs, and sills are common throughout the region, many of the intrusions are along faults. The largest body underlies an area of $\mathbf{0 . 5}$ square kilometer.

Canga, a Cenozoic rock which is sometimes an iron ore, is the only rock of post-Precambrian age in the region. Canga is composed of itabirite colluvium and residuum cemented by limonite.

Parts of four major structural features lie within the western Serra do Curral region. These include (1) the south limb of the Piedade syncline which forms the Serra do Curral and involves rocks of the Minas Series; (2) the Bonfim gneiss dome south of the serra that contains Group II (Itabirito(?) Gneiss) and Group III gneissic facies (Souza Noschese Gneiss); (3) a gneiss dome north of the serra which contains Group IV granitic rocks and Group III gneissic facies; (4) a group of north-trending folds between the Bonfim gneiss dome and the Serra do Curral that involve rocks of the Nova Lima Group. A fifth feature, a thrust fault postulated to have lain on the north side of the Serra do Curral, may have effected the present rock distribution.

Most rocks in the western Serra do Curral were metamorphosed to the greenschist facies of regional metamorphism; higher grade metamorphism is limited to contact zones adjacent to granitic rocks. Typical mineral assemblages of chlorite, white mica, and quartz and small grain sizes in itabirite and iron-formations are indicative of low-grade metamorphism. Petrographic evidence suggests only one period of metamorphism that affected rocks of the Nova Lima Group and Minas Series. However, folding of the Nova Lima Group prior to the deposition of the Minas Series suggests some metamorphism after deposition of the Nova Lima Group and before deposition of the Minas Series. 
Itabirite is the ultimate source of all iron ore in the western Serra do Curral. Itabirite averages between 35 and 45 percent iron or 50 and 65 percent hematite. Redistribution of iron from itabirite by hydrothermal and weathering processes resulted in replacement, detrital, and residual deposits; these closely correspond to the economic classifications of high-grade, low-grade, and potential deposits, respectively.

High-grade replacement deposits are irregular tabular bodies of almost pure compact, intermediate, and soft hematite; the largest deposits are structurally controlled by folds. Several theories have been suggested for the origin of high-grade deposits. The writer considers that the compact ores formed by redistribution of hematite in the pre-itabirite iron-formation and that water released from chert layers in the same formation served as an iron-transporting medium during the post-Minas Series orogeny. Soft and intermediate hematite ores resulted from supergene leaching of compact hematite.

Detrital deposits are surficial blankets of compact hematite and itabirite colluvium. The deposits are derived from the Cauê Itabirite and extend downslope from that formation. If the detritus is unconsolidated it is called rolado; if cemented by limonite it is called canga.

Residual deposits include three gradational types of potential ores which presently can be mined under certain conditions. These ores are structure canga, enriched itabirite, and soft itabirite; all result from the chemical weathering of itabirite in place. Structure canga is itabirite from which most of the quartz has been leached, in which most hematite has been hydrated to limonite, and that is enriched by limonite. Its name results from the fact that at many places it preserves the original itabirite bedding. Enriched itabirite is transitional between structure canga and soft itabirite. The enriched itabirite is itabirite from which much silica has been leached. The hydration of hematite and enrichment of limonite occur in this rock but are not sufficient to completely consolidate the weathered itabirite. Soft itabirite has been softened by the leaching of quartz and may be slightly enriched by limonite.

Total iron resources of the western Serra do Curral include nearly 120 million tons of indicated and inferred reserves of high- and low-grade ores and more than 1,600 million tons of potential resources. Indicated reserves of high-grade ores averaging 67 percent iron include 11 million tons of compact hematite and 13 million tons of sof thematite. Indicated reserves of low-grade ores include 51 million tons of canga averaging 62 percent iron and 8 million tons of rolado averaging 61 percent iron. Inferred reserves include 17 million tons of compact hematite and 19 million tons of soft hematite, both averaging 67 percent iron. Potential resources include 35 million tons of enriched itabirite estimated to contain 55 percent iron, and 1,600 million tons of soft itabirite estimated to contain 50 percent iron.

\section{INTRODUCTION}

\section{GENERAL BACKGROUND}

Some of the largest known iron reserves in the free world occur in Brazil. The recent economic growth and modernization of Brazil and the depletion of other world iron deposits have led to an interest in these ores for both domestic consumption and export. Brazil's largest iron reserves are in the south-central part of the State of Minas Gerais in a region which has become known as the Quadrilatero Ferrifero. A joint study of the Quadrilátero Ferrífero was undertaken in 1946 by by the Brazilian Departamento Nacional da Produção Mineral and the U.S. Geological Survey for the purposes of attracting and aiding commercial interests in the region to broaden the Brazilian economic base, of stimulating an interest in the science of geology, and of training Brazilian geology students. The program is presently incorporated in the Aliança Para o Progresso under the auspices of the Agency for International Development, U.S. Department of State.

The Quadrilátero Ferrifero was divided into the equivalent of nearly thirty-eight $7 \frac{1}{2}$-minute quadrangles. Topographic base maps of these quadrangles were prepared by multiplex methods from aerial photographs at a scale of $1: 25,000$, and a geologic mapping of the quadrangles was done by members of the Departamento Nacional da Produção Mineral-U.S. Geological Survey team. This report concerns the western part of the iron region and is one of a series of U.S. Geological Survey professional papers on the entire Quadrilátero Ferrífero.

\section{COORDINATE SYSTEM}

A 1,000-meter (1 kilometer) grid is used on the plates to aid in locating the outcrops referred to in the text. Specific locations are indicated by coordinates measured north and east from an origin at the southwest corner of each plate. Thus, the reference "(pl. 1, N. 5,000, E. 6,000)" would locate a point 5,000 meters north and 6,000 meters east of the southwest corner of plate 1 . This system is used wherever places cannot be readily located by reference to conspicuous features on the plates.

\section{GEOGRAPHY}

The area described by this report is bounded by lat $20^{\circ} 03^{\prime} 45^{\prime \prime}$ and $20^{\circ} 11^{\prime} 15^{\prime \prime} \mathrm{S}$. and long $44^{\circ} 07^{\prime} 30^{\prime \prime}$ and $44^{\circ} 30^{\prime} 00^{\prime \prime} \mathrm{W}$. The area, which is 538 square kilometers (210 square miles), includes parts of four municípios (equivalent to counties)-Brumadinho, Mateus Leme, Betim, and Itaúna - in two adjacent tiers of three half quadrangles each (fig. 1). The northern tier comprises the south halves of the Serra Azul, Igarapé, and Fêcho do Funil quadrangles, and the southern tier comprises the north halves of the Itatiaiuçu, Sousas, and Brumadinho quadrangles. The two easternmost half quadrangles, Fêcho do Funil and Brumadinho, were studied in more detail than the other four and will be referred to collectively as the Brumadinho area. For convenience, the other four half quadrangles will be referred to collectively as the West End area, and the entire group of six half quadrangles, as the western Serra do Curral.

The western Serra do Curral is chiefly an agricultural region, but a fifth of the population is dependent on mining and related activities. The major crops are corn, 


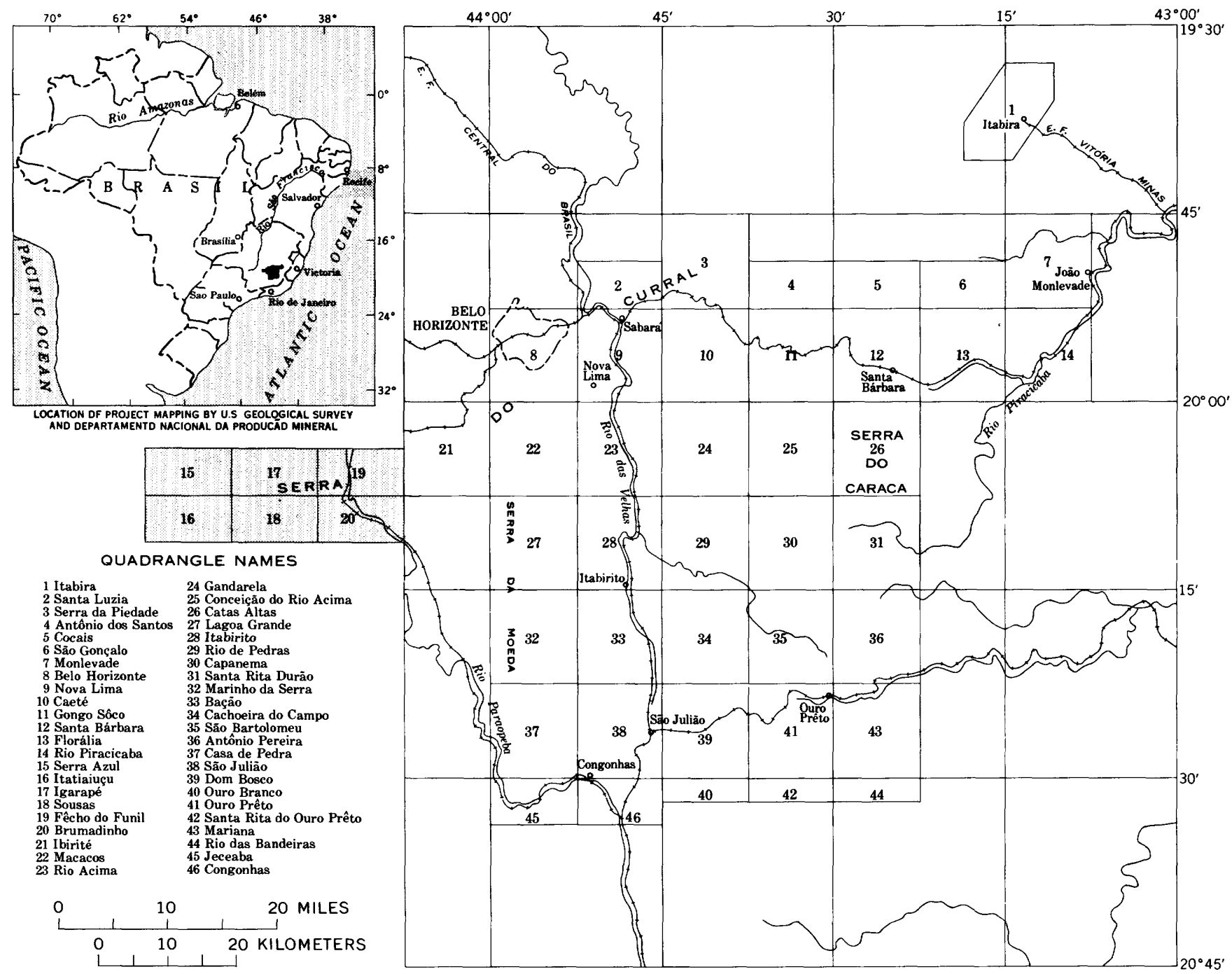

Figure 1.-Index map of the Quadrilatero Ferrifero showing the western Serra do Curral. Report area is shaded.

oranges, bananas, mandioca, coffee, sugarcane, rice, and garlic. Cows and pigs are raised, chiefly for sale in nearby Belo Horizonte, the State capital. Horses and mules are raised for draft animals and for transportation.

A number of small communities lie within the area. Among the larger are Brumadinho (population 2,000), seat of the minicipio of the same name. Tijuco, Souza Noschese, Fêcho do Funil, and Inhotim are mining communities, and the latter three are loading stations on the Estrada de Ferro Central do Brasil (Brazilian Central Railroad). Itaguá, Igarapé, Serra Azul, and Sousas are farming communities. Two other towns lie near theWest End area, Itatiaiuçu and Itaúna. Itatiaiuçu (population 600) is 1 kilometer south of the West End area and has a 24-ton furnace for making pig iron. Itaúna (population 20,000) is 8 kilometers west of the West End area. It is a progressive town with a diversified economy that depends upon hydroelectric power, mining, smelting, farming, and railroading.
Four principal roads give access to the region. The Belo Horizonte-São Paulo asphalted highway (BR-55) transects the central part of the area from northeast to southwest and passes the town of Igarapé. An allweather gravel road from Barreiro to Bonfim passes through the town of Brumadinho. The Belo HorizonteUberaba highway (BR-31), which is paved with asphalt, cobblestones, or gravel, parallels the north boundary several kilometers from the mapped area. An all-weather gravel spur leads from this road to Itauna, and another usually passable, graveled spur connects Serra Azul with the main highway (BR-31). A 4-kilometer well-maintained dirt road connects the town of Itatiaiuçu with BR-55, and a dry-season road connects Itatiaiuçu with Itaúna. All-weather secondary roads connect the mining areas with nearby towns and loading stations, and jeepable roads give some access to other parts of the area.

A 1.6-meter-gage line of the Estrada de Ferro Central 
do Brasil, connects Belo Horizonte and Rio de Janeiro and crosses the Brumadinho area. Loading stations within the area are at Fêcho do Funil, Souza Noschese, Inhotim, Brumadinho, and Alberto Flôres. An electrified narrow gage line of the Rêde Mineira de Viação runs north of the area, connecting Itauna and Belo Horizonte.

The Quadrilátero Ferrífero has a subtropical climate. The temperature ranges from $5^{\circ}$ to $35^{\circ} \mathrm{C}\left(41^{\circ}\right.$ to $\left.95^{\circ} \mathrm{F}\right)$, and the average daytime temperature is $20^{\circ} \mathrm{C}\left(68^{\circ} \mathrm{F}\right)$. Belo Horizonte, the State capital, has about 150 centimeters (59 inches) of annual rainfall, but more rain falls at the higher altitudes which prevail over much of the region. There are two seasons, a wet summer from November through February and a dry winter from April through September. The months of March and October are transitional between the two seasons. In the middle of the summer there is a dry period of about 10 days which is called the veranico, or little summer. Rainless days occur intermittently during the rainy season, and rains rarely occur during the dry winter season.

Most vegetation, particularly where underlain by granitic rocks, is thick but open and consists of grasses, shrubs, and small trees, and the terrain is easily passable. However, many dense forests exist near streamheads on the mountainsides. Older forests, those which have not been cut for 15-20 years or more, form a parasollike cover and are readily passable. Younger forests have many small trees, vine thickets, and cane breaks and are very difficult to traverse.

The western Serra do Curral region can be divided into seven informal physiographic divisions: Itauna uplands, Igarapé pediments, Serra do Curral, Itatiaia hills, Serra das Queias, Brumadinho hills, and Alberto Flôres uplands (fig. 2). Each of the divisions has developed from the erosion of different rocks: the Alberto Flôres uplands from Itabirito(?) Gneiss, the Brumadinho hills from Souza Noschese Gneiss, the Serra das
Queias from rocks of the Nova Lima Group containing iron-formations, the Itatiaia hills from rocks of the Nova Lima Group without iron-formations, the Serra do Curral from rocks of the Minas Series, the Igarape pediments from gneiss similar to the Souza Noschese Gneiss and rocks of the Sabara Formation, and the Itauna uplands from granodiorite gneiss.

The most rugged topography has developed where resistant itabirite and iron-formation are present in the Serra do Curral and Serra das Queias; the gentlest topography has developed on granitic rocks. The highest altitudes occur along the ridge forming the crest of the Serra do Curral. The highest peaks are Pico de Itatiaiuçu (1,435 meters) and Pico dos Tres Irmãos (1,422 meters). Several unnamed peaks have altitudes between 1,300 and 1,400 meters. The steepest slopes occur on the flanks of mountains in the Serra das Queias; however, as a result of the low inclination of beds, the summits in this range are rounded. The highest altitudes in this serra are slightly less than 1,300 meters. The Itatiaia hills were once a pediment on the south side of the Serra do Curral which has been dissected by tributaries of the Ribeirão Vermelho. Most of the hill crests lie between 900 and 1,000 meters. The Alberto Flôres uplands and Brumadinho hills have similar topography, most hill crests having altitudes between 800 and 900 meters. The Igarape pediments on the north side of the Serra do Curral are dissected by tributaries of the Ribeirão Serra Azul. Most of the pediment tops are flat planes between altitudes of 800 and 900 meters. The topography of the Itauna uplands is more abrupt than that of the granitic rocks in the Igarape pediments, and most of the higher altitudes are between 950 and 1,100 meters. Total relief of the area is 715 meters $(2,340 \mathrm{ft})$.

The principal drainage is through the Rio Paraopeba, which flows north through the Brumadinho area. The southwest corner of the West End area is drained by

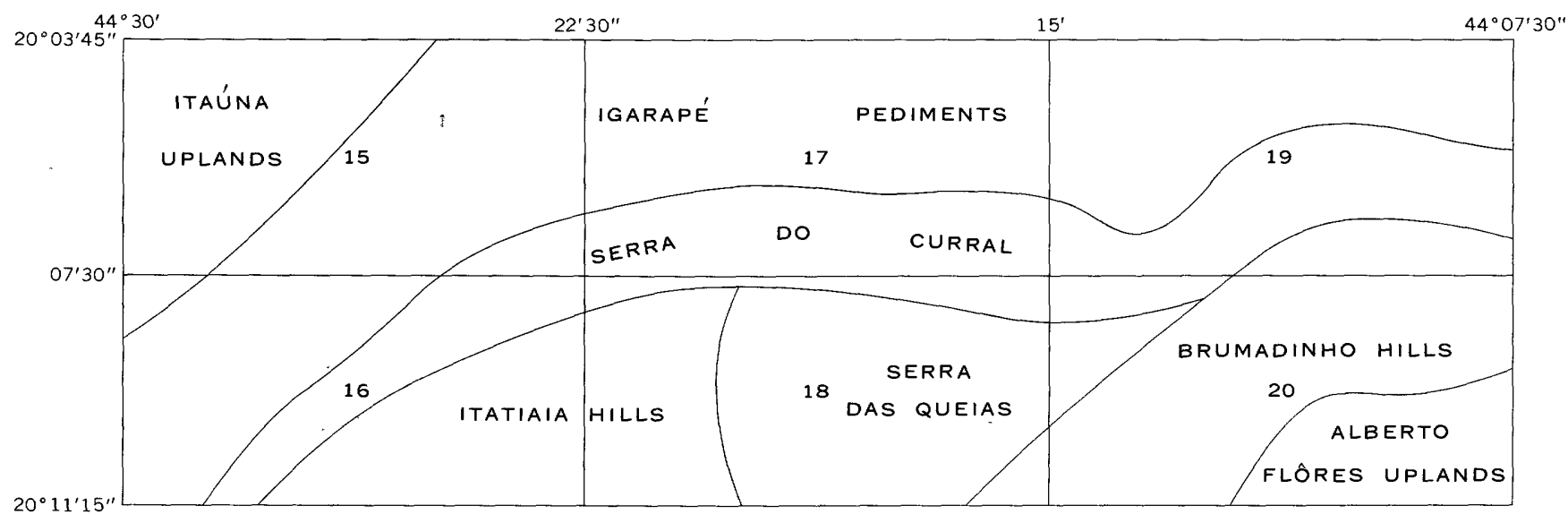

Figure 2.-Physiographic divisions (informal) of the western Serra do Curral region. Names of quadrangles are shown in figure 1. 
tributaries of the Rio São João, which in turn empties into the Rio Pará. The Paraopeba and Pará are major tributaries of the Rio São Francisco, by which all waters of the region reach the Atlantic Ocean.

\section{PREVIOUS INVESTIGATIONS}

The geology of the Quadrilattero Ferrifero has been studied for more than 150 years. Despite this long interest, the region has not been well known until recent years because most early studies were concerned with limited aspects, such as individual mines or minerals, and because of the lack of topographic base maps. Perhaps the most informative of the early reports, in part concerning gold deposits in the Quadrilatero Ferrifero, is that of Baron W. L. von Eschwege (1833).

The modern period of investigation began near the turn of the century with the work of Henri Gorceix (1881, 1883, 1884), first Director of the School of Mines at Ouro Preto, and Orville A. Derby (1881, 1896, 1901, 1906, 1910). About 1910 a group of North American geologists investigated the deposits and regional geology of the iron region and published several scientific papers. Among the more important of these papers are those of Leith and Harder (1911), Leith (1917), Harder (1914), and Harder and Chamberlin (1915). The most comprehensive accounts of the general geology and mineral resources, based on extensive original work and an exhaustive search of the literature, were compiled by Freyberg (1932, 1934). A bilingual outline of the geology of the Quadrilatero Ferrífero and a geologic map were prepared by geologists of the Departamento Nacional da Produção Mineral and the U.S. Geological Survey (Departamento Nacional da Produção Mineral, 1959); it synthesizes the studies carried out by geologists of the two organizations in their joint program through 1958.

Since 1925 the number of papers by Brazilian geologists has steadily increased, and a complete list would contain many names and hundreds of papers. Among the more significant contributions are those by Barbosa (1934, 1954), Guimarães (1931, 1935, 1937, 1946, 1951, 1953, 1958), Guimarães and Barbosa (1934), and Moraes and Barbosa (1939).

\section{PRESENT INVESTIGATION}

Mapping of the western Serra do Curral was carried out in two periods. The Brumadinho area was mapped on a detailed reconnaissance basis between November 1957 and April 1959 and included detailed mapping of the various iron deposits. The West End area was mapped on a reconnaissance basis between April and July 1961.

Several published geologic studies of the Quadrilátero Ferrífero (Guild, 1957; Gair, 1962; Johnson,
1962; Dorr and Barbosa, 1963; Pomerene, 1964; Reeves, 1966; and Wallace, 1965) were useful in providing a background for the present investigation. The studies of Gair (1962) and Pomerene (1964) report on the eastern and central parts of the Serra do Curral. The unpublished work of B. P. Alves discusses the Caeté district at the east end of the range.

An excellent summary of mineral deposits in the valley of the Rio Paraopeba by Pimentel de Godoy (1957) was useful in the preparation of the section on iron deposits.

\section{ACKNOWLEDGMENTS}

The writer is indebted to many people and organizations for assistance throughout the preparation of this report. Principal among these is the Departamento Nacional da Produção Mineral, which provided chemical analyses, thin sections, and library facilities. Special thanks are given to Avelino Ignacio de Oliveira, Director; José Alves, Chefe da Divisão do Centro; Cássio Mendonça Pinto and J. B. Araujo, chemists; Elysario Távora, mineralogist; and Sr. Santana who prepared the 90 thin sections studied in the course of this report.

The Instituto de Tecnologia Industrial in Belo Horizonte also offered its library and laboratory facilities. Prof. Djalma Guimarães was helpful in familiarizing the writer with Brazilian geologic literature, and Dr. Claudio V. Dutra provided spectrographic analyses.

Members of the Wm. H. Müller Co. provided accommodations and assisted in visiting mine operators in the Brumadinho area. Rudolf van Nordheim, mining engineer, Nemure Facuri, manager of the Candú mine, and Iphygenio Soares Coelho, consulting geologist, were especially helpful at field headquarters in Souza Noschese.

Jurgen Eichler of Cia. Mineração Ferro e Carvão provided information and analyses resulting from exploration at Córrego do Feijão.

Eden Lazzarini served as "ajudante" during the work in the Brumadinho area. He was a versatile field assistant who translated the author's Portuguese into the Portuguese spoken by the local inhabitants.

Mr. Joel B. Pomerene of the U.S. Geological Survey, who mapped in the adjacent Ibirite quadrangle, familiarized the writer with the stratigraphy of the Serra do Curral, and Dr. Norman Herz, U.S. Geological Survey, aided in the study of the granitic rocks.

\section{GEOLOGIC SETTING QUADRILÁTERO FERRIFERO}

The rocks of the Quadrilatero Ferrifero have been divided into three series of metasedimentary rocks- 
the Rio das Velhas, Minas, and Itacolumí Series-and into four numbered groups of granitic rocks, Group III of which is divided into granitic and gneissic facies. All these rocks are assigned to the Precambrian. The chronologic order of six of these rock divisions is as follows, from oldest to youngest: Group I, Rio das Velhas Series, Group II, Minas Series, Itacolomí Series, and Group III gneissic facies. The exact temporal positions of Group III granitic facies and Group IV are uncertain.

Most of the recognizable structural features in the Quadrilatero Ferrífero were formed during the orogeny accompanying the emplacement of the youngest granitic rocks. These features are best observed in the Minas Series because it is better exposed and has been subjected to less diastrophism than the Rio das Velhas Series and is more widely distributed than the younger, Itacolomi Series. The Minas Series was deposited on a shelf area. The writer thinks that the shelf bordered a geosyncline- the axis of which was to the east, southeast, and south of the Quadrilatero Ferrifero-and that the axis is approximated by a band of charnockites that roughly parallels the Minas Gerais-Espirito Santo boundary from north to south and then bends west toward the town of Tres Rios. During the last orogeny the Minas Series was folded into relatively narrow synclines between broader granite-cored domes, and thrust faults developed with displacement normal to the axis of the geosyncline. Subsequent erosion to within perhaps 1,000 meters of the roots of the Minas Series synclines resulted in preservation of only the keels of the folds.

At least three major orogenic periods accompanied by emplacement of granitic rocks and regional metamorphism occurred in the Quadrilatero Ferrífero (Herz and others, 1961, p. 1112), but there may have been other periods of metamorphism which are not represented by intrusive granite. Rocks involved in the earliest of the three orogenies are exposed in a small area near Engenheiro Corrêa in the Bação quadrangle. The early orogeny apparently resulted in a high-grade regional metamorphism which produced gneisses and garnet amphibolites (Herz, in Departamento Nacional da Produção Mineral, 1959, p. 99-100). The effects of the second orogeny are questionable because the rocks involved, the Nova Lima Group, are of the same metamorphic grade as the younger rocks of the Minas Series, which were only affected by the third orogeny. Both rock divisions have been metamorphosed to the greenschist facies except in contact zones with granitic rocks, where the metamorphic grade is usually higher.

The Minas Series has been the most economically important of the rocks in the Quadrilátero Ferrifero because it has been the source of all the iron and of much of the gold, aluminum, and manganese mined in the region. The largest and best known mines are the iron mines at Congonhas (Guild, 1957) and Itabira (Dorr and Barbosa, 1963). However, there has been important gold production from the Nova Lima Group of the Rio das Velhas Series, notably from the Morro Velho mine at Nova Lima where more than $7,300,000$ ounces of gold was produced between 1834 and 1955 (Gair, 1962, p. 54).

The primary iron deposits are replacements in itabirite; they formed during the last orogeny. Other iron deposits were formed by mechanical and chemical processes associated with the weathering of primary deposits and itabirite. The manganese deposits are both primary veins of unknown origin and deposits formed during the weathering of manganiferous dolomites. The aluminum deposits were formed during the weathering of argillaceous rocks and poorly consolidated Tertiary sediments. The gold deposits in the Nova Lima Group and some in the Minas Series are primary deposits of unknown origin in which there has been surficial concentration resulting from weathering. The origin of the gold found in Minas Series quartzites is questionable, and the deposits may be ancient placer deposits or of hydrothermal origin or both.

\section{WESTERN SERRA DO CURRAL}

At least five of the major rock divisions of the Quadrilátero Ferrifero are represented in the western Serra do Curral. All rocks in the Rio das Velhas Series are tentatively assigned to the Nova Lima Group. Group II rocks are represented by Itabirito(?) Gneiss. Gneiss in the northwest corner of the area belongs to Group IV. All three groups of the Minas Series-the Caraça, Itabira, and Piracicaba-are present, but the Itacolomí Series is absent. Group III gneissic facies is represented by the Souza Noschese Gneiss in the southern part of the Brumadinho area and by gneiss in the northern part of the West End area. Two minor rock types, intrusive diabase and canga, a surficial Cenozoic rock, are also found.

The major structural features of the western Serra do Curral include parts of two gneiss domes, a syncline limb containing the Minas Series, and folded rocks of the Nova Lima Group. A major thrust fault, obliterated by granite, is postulated to explain the present rock relationships. The fringes of two gneiss domes which lie to the north and south are within the mapped area. These domes have cores of older granitic rocks around which younger granitic rocks form rims, adjacent to the region's stratified rocks. The south limb of a syncline involving the Minas Series, overturned at most places, strikes roughly $\mathrm{N}$. $70^{\circ} \mathrm{E}$. across the 
quadrangles and forms the Serra do Curral. The Nova Lima Group has been flexed into north-trending folds. The fold flanks generally dip gently to moderately and thus appear to have been less intensely folded than the Minas Series. The location of principal structures and the general rock distribution are shown in figures 3 and 4 .

Most of the western Serra do Curral rocks are characterized by low-grade regional metamorphism of post-Minas age. Rocks of the Nova Lima Group were probably metamorphosed prior to the deposition of the Minas Series. If so, metamorphic grade either did not exceed that of post-Minas metamorphism or, if the older metamorphism was of a higher grade, its effects completely retrogressed during the postMinas metamorphism.

Economic interest in the western Serra do Curral has been limited to rocks of the Minas Series and to Cenozoic deposits derived from these rocks. The three most important ore bodies are the Candú compact hematite deposit; the Tijuco deposit, areally the largest deposit of compact hematite rolado in the Quadrilatero Ferrifero; and the Córrego do Feijão deposit, consisting of compact and soft hematite, canga, rolado, and alluvial ores. Three other small compact hematite deposits are known, and many canga and rolado iron deposits are present. A few prospects for manganese are in the Gandarela and Fêcho do Funil Formations, but no commercial ore has been found.

\section{STRATIGRAPHY}

Stratified rocks occupy 273 square kilometers, about half the western Serra do Curral, and trend from northeast to southwest across the mapped area (pls. 1, 2, 3). The rocks are assigned to two major stratigraphic divisions, the Rio das Velhas and Minas Series, both of Precambrian age but separated by an angular unconformity. Together the two series have a calculated and measured thickness of 2,300 meters (table 1).

The Rio das Velhas Series, the older of the two, is composed of three groups elsewhere but is represented here by only the Nova Lima Group. This group occupies 147 square kilometers in the southern and southwestern parts of the area and lies between the Souza Noschese Gneiss to the south and the Minas Series to the north. The minimum thickness of the Nova Lima Group is estimated to be 900 meters.

The correlation and age of rocks assigned to the Nova Lima Group are problematical throughout the entire Quadrilatero Ferrifero, including the western Serra do Curral. The principal difficulty stems from the fact that these rocks have not yet been mapped in detail and stratigraphic succession within the group
TABLE 1.-Stratigraphic column for Precambrian rocks in the western Serra do Curral

[Numbers in parentheses are thicknesses, in meters; thicknesses followed by an asterisk are estimated]

\begin{tabular}{|c|c|c|c|}
\hline Series & Group & Formation & Description \\
\hline \multirow{5}{*}{ 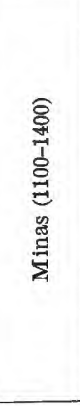 } & \multirow[t]{2}{*}{$\begin{array}{r}\text { Piracicaba } \\
(610-1000)\end{array}$} & Sahará Formation $(400)^{*}$ & $\begin{array}{l}\text { Tuff, conglomerate, } \\
\text { phyllite. }\end{array}$ \\
\hline & & $\begin{array}{l}\text { Barreiro Formation (0-40) } \\
\text { Tabowies Quartzite (30-100) } \\
\text { Focho do Funil Forma- } \\
\text { tion (100-410) } \\
\text { Cercadinho Formation } \\
\text { (80-120) }\end{array}$ & $\begin{array}{l}\text { Carbonaceous schist. } \\
\text { Quartizite. } \\
\text { Dolomitic phyllite. } \\
\text { Ferruginous quartzite, } \\
\text { phyllite. } \\
\end{array}$ \\
\hline & \multirow[t]{2}{*}{ Itabira $(60-350)$} & $\begin{array}{l}\text { Gandarela Formation } \\
(0-170)\end{array}$ & $\begin{array}{l}\text { Itabirite, phyllite, dolo- } \\
\text { mite. }\end{array}$ \\
\hline & & Caue itabirite (60-180) & Itabirite. \\
\hline & Caraça (60-100) & Batatal Formation (30) & $\begin{array}{l}\text { Phyllite. } \\
\text { Quartzite, phyllite. }\end{array}$ \\
\hline 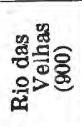 & $\begin{array}{l}\text { Nova Lima } \\
(900)\end{array}$ & $\begin{array}{l}\text { Upper(?) part (600)* } \\
\text { Lower(?) part }(300)^{*}\end{array}$ & $\begin{array}{l}\text { Schist, iron-formation. } \\
\text { Schist. }\end{array}$ \\
\hline
\end{tabular}

has not been recognized. However, all rocks presently assigned to the Nova Lima Group by Departamento Nacional da Produção Mineral-U.S. Geological Survey geologists have a general lithologic similarity in that they are mostly pelitic rocks with locally abundant iron-formation.

The term Nova Lima has been used in this report as a matter of convenience and refers to all the stratified pre-Minas Series rocks in the western Serra do Curral. Nova Lima rocks of the western Serra do Curral are more than 40 kilometers from the type area of the Nova Lima Group (Dorr and others, 1957, p. 18) and more than 20 kilometers from the nearest rocks referred to as Nova Lima Group (Pomerene, 1964, p. 8). Because of this lack of continuity and stratigraphic information, the rocks called Nova Lima Group in the western Serra do Curral may or may not be the same as or be equivalent to rocks assigned to the Nova Lima Group elsewhere.

The Minas Series occupies 126 square kilometers and lies in a band that strikes approximately N. $70^{\circ} \mathrm{E}$. and thins from east to west across the area. The series is bounded on the south by the Nova Lima Group and Souza Noschese Gneiss and on the north by gneiss tentatively correlated with the Souza Noschese Gneiss. The Minas Series is composed of three groups that crop out in three subparallel bands and aggregate a maximum thickness of 1,400 meters. From oldest to youngest and south to north, these are, respectively, the Caraça, Itabira, and Piracicaba Groups. This division separates the principal rocks of chemical origin from underlying clastic rocks and from overlying clastic rocks, dolomite, and rocks of volcanic origin (Dorr and others, 1957, p. 23-24). The series represents three depositional phases which are separated by two disconformities 


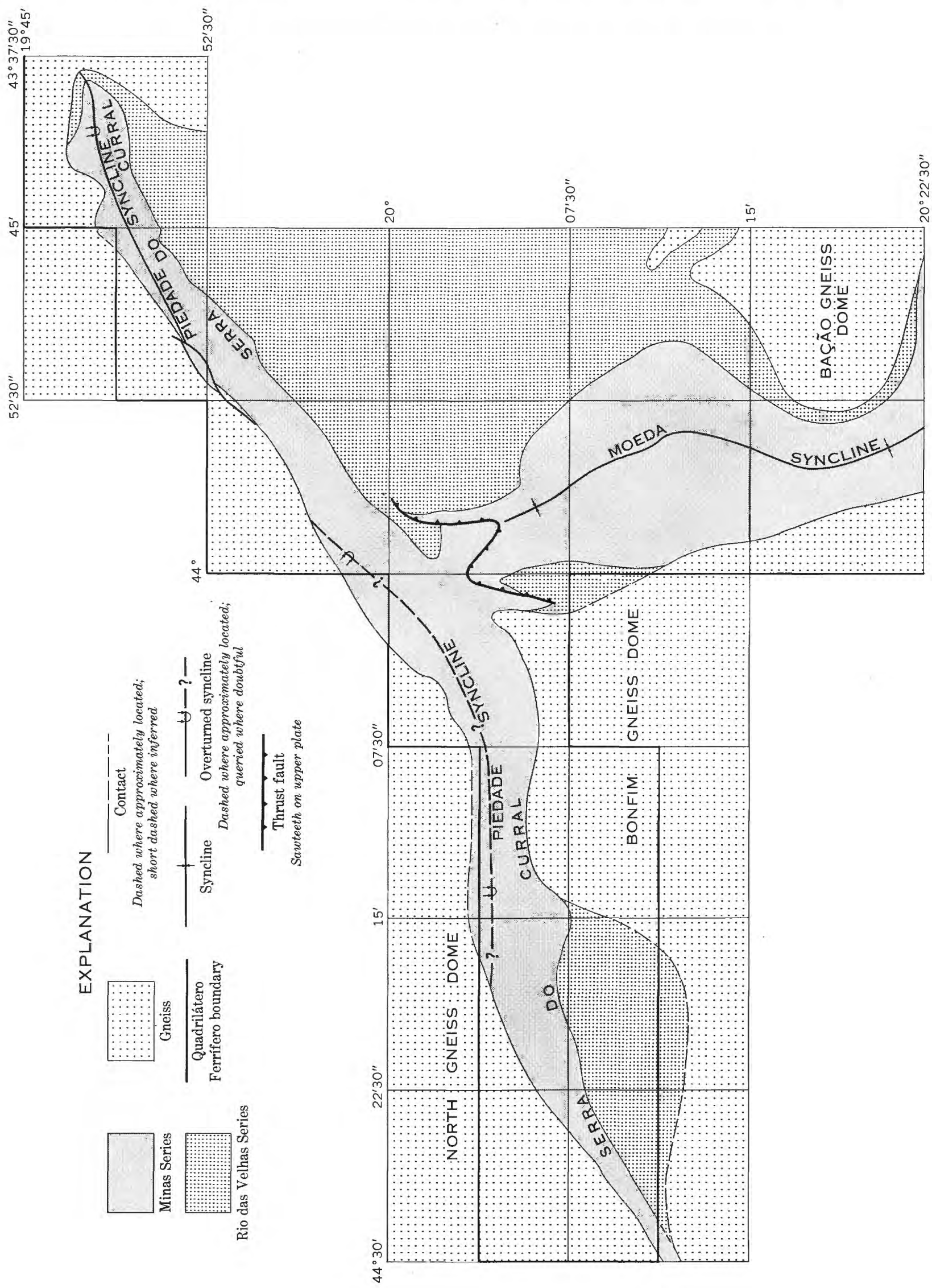




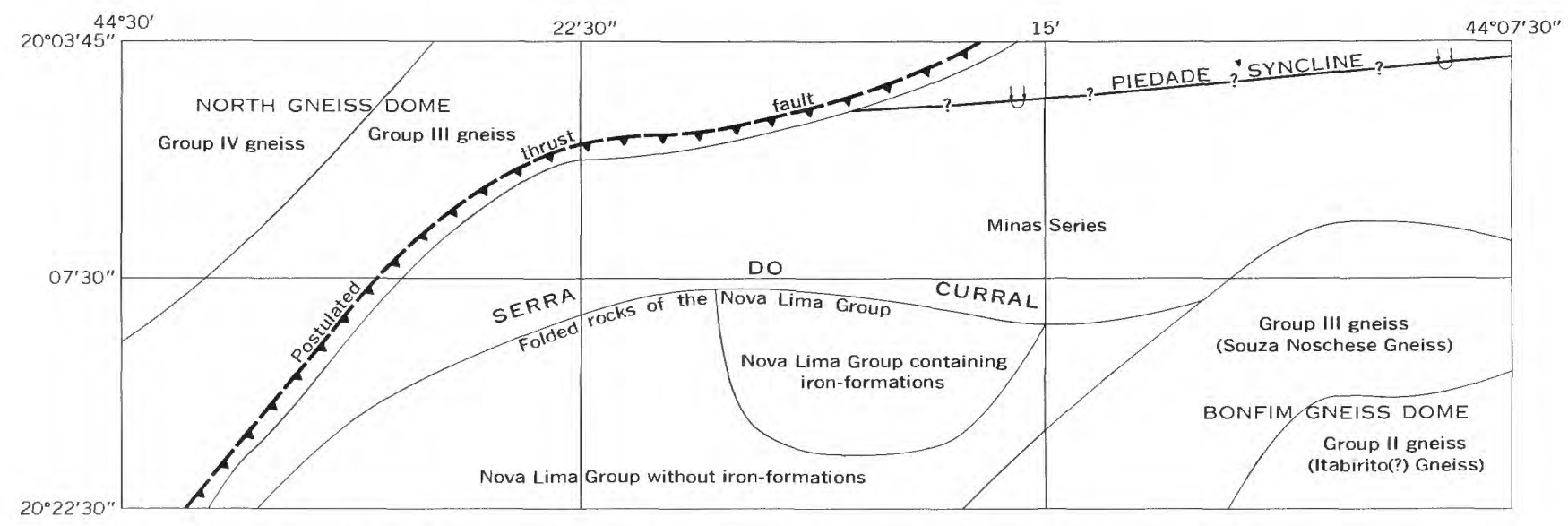

Frgure 4.-Principal structures and general rock distribution in the western Serra do Curral.

(table 1). However, these phases do not correspond to the division into groups. The Caraça and Itabira Groups represent one cycle of deposition and are separated from the Piracicaba Group by the lower disconformity. The Piracicaba Group represents two depositional phases, one represented by the lower four formations and the other by the upper formation. Although the contact between the two upper phases is considered a disconformity in this region, it has been interpreted as a transitional contact in the adjoining area to the east (Pomerene, 1964, p. 27).

\section{RIO DAS VELHAS SERIES NOVA LIMA GROUP}

The Nova Lima Group consists mostly of schist, phyllite, and iron-formation. Although some ironformations were mapped as separate units (pl. 2), no formal division of the group into formations has been attempted. However, such a division may be possible on the basis of the distribution of iron-formation, which is more restricted in areal distribution than schist and phyllite. As the West End area was not mapped in adequate detail to make this division at the scale of the map plates, the separation is indicated only on the small-scale map in figure 4 . The gross rock relations as shown in that figure suggest that the part of the group containing iron-formations is in the trough of an eroded syncline and overlies the part of the Nova Lima Group without iron-formations. These two divisions are shown as upper(?) part and lower(?) part in table 1.

The Nova Lima Group is separated from the Minas Series by a profound unconformity. Although the contact between the two rock units is exposed at only one place, the marked difference in structure on opposite sides of the contact leaves no doubt as to its nature. The Nova Lima Group contains north-trending folds, and the major fold in the Minas Series trends east. Where the Minas Series is in contact with the axes of Nova Lima folds there is an apparent conformity of units, but east and west from the axial areas the divergence in attitudes is obvious. This relation is best seen in the northern part of the Serra das Queias (pl. 2) where resistant iron-formation units form marker beds indicating the structure of the Nova Lima Group.

The base of the Nova Lima Group is unknown in the western Serra do Curral, and its location is questionable everywhere in the Quadrilatero Ferrifero. The original base of the group may have been destroyed by intrusion of either the Itabirito(?) Gneiss or the Souza Noschese Gneiss.

A minimum thickness of 900 meters is estimated for the Nova Lima Group. An estimated 600-meter thickness for the upper(?) part of the Nova Lima Group is based on differences in altitude of exposures on vertical fold axes. A similar calculation for the lower(?) part indicates a thickness of 300 meters.

\section{SCHISTS AND PHYLLITES}

Schists and phyllites form approximately 90 percent of the Nova Lima Group. The rocks, nearly everywhere weathered, are various shades of brown, gray, and red. Several kinds of schist and phyllite-chiefly composed of sericite, fine-grained quartz, chlorite, and carbonaceous material-have been recognized, but the lack of fresh outcrops and the presence of abundant soil and vegetal cover have made it impossible to map the lateral continuity of individual types. Therefore, all schist and phyllite were mapped as one unit.

Unweathered schist was found at only three places. Two are in the Brumadinho quadrangle near the contact with Souza Noschese Gneiss; both are in the valley bottom on the northeast side of the road from Brumadinho to Pau de Vinho mine (pl. 1, N. 6,400, E. 1,000 , and N. 6,600, E. 900). The third is in the Sousas 
quadrangle in the stream bed of Córrego Grande (pl. 2, N. 4,000 , E. 12,200).

In thin section these rocks were seen to be finegrained strongly foliated sericite-quartz, quartz-sericite, and chlorite schists. The quartz-sericite schist contains less than 2 percent black heavy opaque minerals, and the chlorite schist contains about 5 percent finegrained quartz. Small garnets, as much as $2 \mathrm{~mm}$ in diameter, make up several percent of the schists in the fresh exposures closest to the Souza Noschese Gneiss (pl. 1, N. 6,400, E. 1,000).

\section{FERRUGINOUS PHYLLITE AND IRON-FORMATION}

Ferruginous phyllite and iron-formation make up about 10 percent of the upper(?) part of the Nova Lima Group but were not found in the lower(?) part of the group; these are the units most resistant to weathering. Where the rocks are gently folded they form ledges and cliffs; where moderately folded and steeply inclined they form ridges. These rocks constitute marker beds which show the structure of the Nova Lima Group (pl. 2). Some beds were traced along strike for more than 4 kilometers; detailed mapping will undoubtedly prove some of them to be more extensive.

Beds of ferruginous phyllite are more abundant than beds of iron-formation, but the two lithologies are intergradational, laterally and vertically. At some places the gradation is abrupt, within a few millimeters, and at others it is more gradual, through several meters of aluminous iron-formation. Most primary iron minerals have been hydrated to limonite, but small hematite flakes are commonly found, especially in roadcuts. The beds range in thickness from a few centimeters to more than 10 meters.

Iron-formation is almost entirely composed of hematite and quartz concentrated in alternating laminae (fig. 5). The laminae are seldom as much as $2 \mathrm{~mm}$ thick, most are less than $0.5 \mathrm{~mm}$, and quartz-rich laminae average about twice the thickness of hematite-rich laminae. Grains range from 0.01 to $0.03 \mathrm{~mm}$ in diameter; the average hematite grain is slightly longer than the average quartz grain. The only other mineral observed is magnetite, which occurs as octahedra 0.03

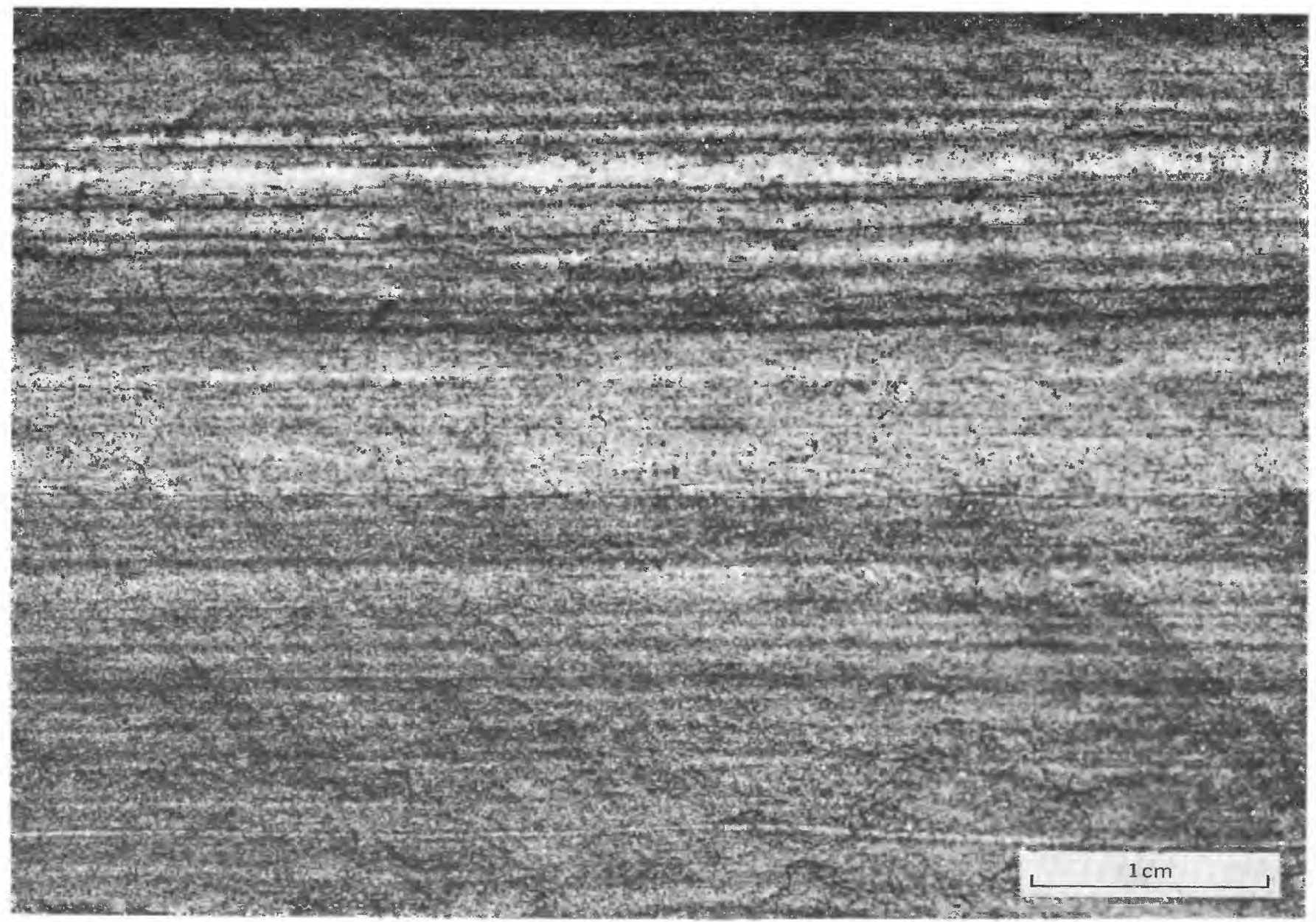

Figure 5.-Iron-formation of the Nova Lima Group. Hematite-rich laminae, dark; quartz-rich laminae, light. 
$\mathrm{mm}$ or less in diameter; it is estimated to be less than 5 percent of the iron-formation. Fresh iron-formation is light bluish gray but is various shades of red and brown at most outcrops as a result of the hydration of hematite to limonite.

Iron-formation in the western Serra do Curral was determined to be oxide facies. In this respect it differs from iron-formation in the Nova Lima Group at the type locality, where the iron-formation was determined to be carbonate facies (Gair, 1962, p. 21). Samples of fresh iron-formation and aluminous iron-formation were collected from a newly quarried bank in a roadcut on the Belo Horizonte-São Paulo Highway (pl. 2, N. 6,300 , E. 6,700). Analyses of these samples yielded 52.4 and 41.4 percent ferric oxide and 0.9 and 2.9 percent ferrous oxide, respectively (table 2, samples 1, 2). Neither analysis indicated the presence of iron carbonate, nor was any iron carbonate seen in thin sections of the same samples.

\section{OTHER ROCKS}

Quartzite, conglomerate, and quartz-sericite schist form a minor part of the Nova Lima Group. These units contain as much as 20 percent sericite and locally contain several percent chlorite and biotite. Arenaceous beds have not been found in thichnesses exceeding several meters, and, as they do not crop out in such a manner that their lateral continuity can be traced, they have been included with schist and phyllite on the geologic maps (pls. 1, 2, 3). No carbonate beds were recognized. However, some are possibly present but so weathered and covered as to be unrecognizable. Carbonate beds are known elsewhere in the Quadrilátero Ferrífero (Gair, 1962, pp. 10-12, 14-15, 23-25).

\section{MINAS SERIES}

CARACA GROUP

The Caraça Group consists of metamorphosed clastic sediments which lie in a relatively thin band on the south flank of the Serra do Curral. The group is poorly exposed, partly because its weathers readily and partly because it is adjacent to the Caue Itabirite whose colluvium covers the group at many places. The group is more resistant to weathering than the Souza Noschese Gneiss, however, and where the base of the group is in contact with the gneiss (pl. 1) the contact has topographic expression which can be traced on aerial photographs at many places even though the rocks are not exposed. The position of the contact is difficult to determine where the base of the group is in contact with the Nova Lima Group (pls. 2, 3), which weathers in a manner similar to the Caraça Group.

The Caraça Group is divided in the east into two formations, the older Moeda Formation and the younger Batatal Formation, but has not been divided in the west because of limited time and poor exposures. The contact between the Moeda and Batatal Formations is fairly abrupt but transitional; the zone of gradation at most places is less than 3 meters thick.

\section{MOEDA FORMATION}

The Moeda Formation is composed of silty phyllite and quartzite. The phyllite is grayish green, light brown, brownish red, and brown. As seen in thin section the phyllite consists of sericite and silt-sized particles of quartz. All phyllite of the Moeda Formation contains some arenaceous material and can be distinguished from Batatal Formation phyllites which lack arenaceous material except near the contact with the Moeda Formation. The quartzites are very fine to medium grained and are light shades of gray, brown, and brownish red. They are composed of quartz, sericite, and small amounts of black opaque heavy minerals. Sorting and bedding are poor.

Quartzite beds are concentrated near the base of the formation and phyllites near the top, although a quartzite bed forms the top unit of the formation at places. No attempt has been made to correlate these divisions with the lower quartzite member, middle phyllite member, and upper quartzite member of the Moeda Formation at its type locality in the Serra da Moeda, 20 kilometers to the southeast (Wallace, 1958 , p. 59 ).

The Moeda Formation gradually becomes finer grained and more argillaceous westward along the Serra do Curral. Conglomerate, common to the east in the central part of the range (Pomerene, 1964, p. 11) and to the southeast in the Serra da Moeda (Wallace, 1965), is unknown in the western Serra do Curral.

The contact between the Moeda Formation and the Nova Lima Group, as previously described, is an angular unconformity. In the mapped area, the only known exposure of the contact is on the road from Brumadinho to the Bocaina quarry (pl. 1, N. 7,500, E. 800).

A thin metasomatized zone exists between the base of the Moeda Formation and the Souza Noschese Gneiss. This zone is exposed in two roadcuts near the Candú mine and on both sides of the Rio Paraopeba water gap through the Serra do Curral (pl. 1). Comparison of the thickness of the Moeda Formation at the Rio Paraopeba with a complete thickness of that formation near the Bocaina quarry indicates that only a meter or two of the Moeda Formation has been incorporated into the gneiss. This was verified by studying thin sections of the gneiss taken near the contact.

The Moeda Formation generally ranges in thickness from 35 meters on the east side of the Brumadinho 


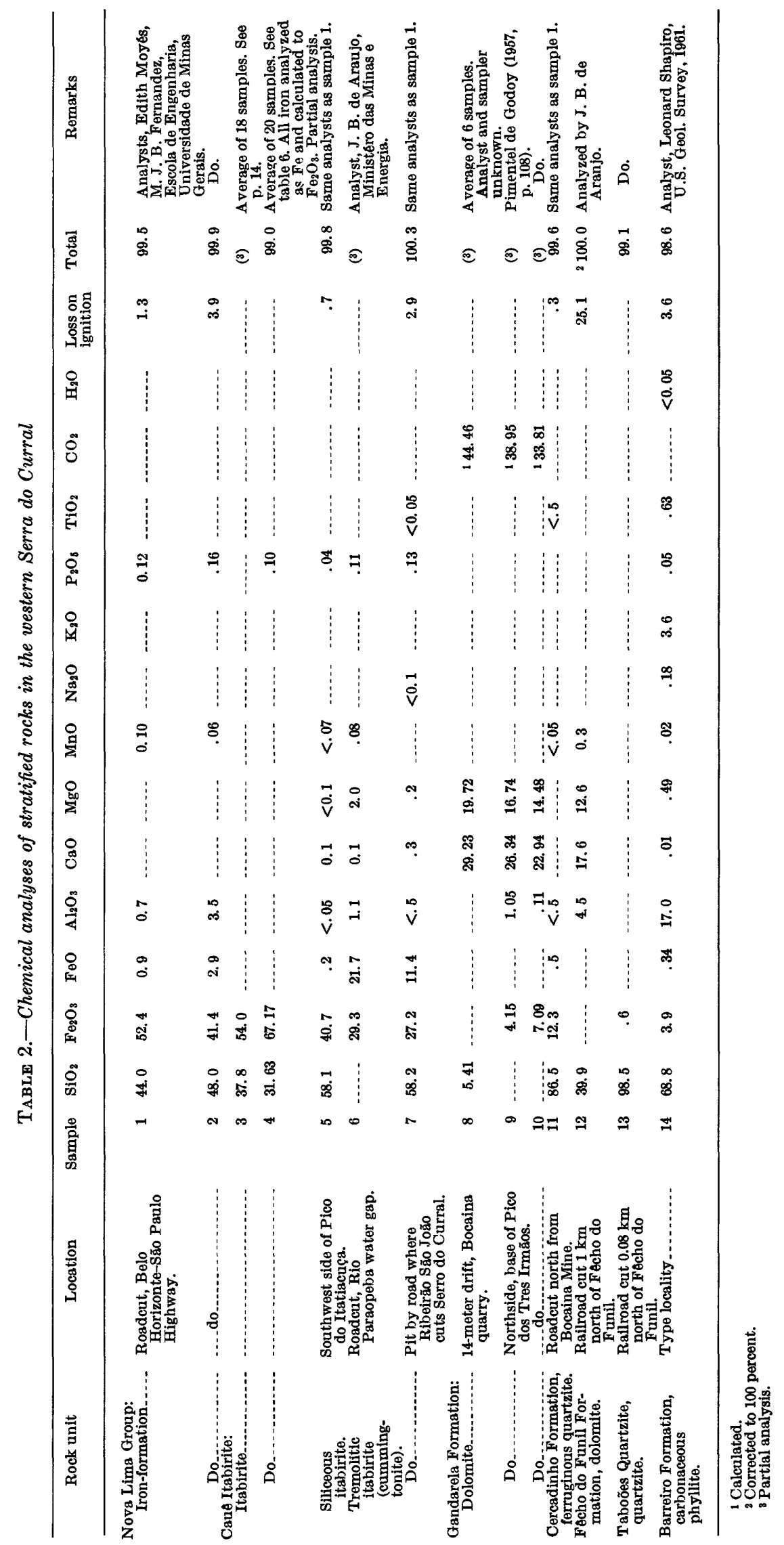


area to 70 meters in the West End area. One complete section was measured on the east side of the Rio Paraopeba.

Section of the Moeda Formation measured in a roadcut on the east side of the Rio Paraopeba water gap through the Serra do Curral

[Section given from top to base; thicknesses in meters]

$$
\text { Description }
$$$$
\text { Top Base } \underset{\substack{\text { Thick- } \\ \text { ness }}}{ }
$$

Quartzite, gray, fine- to medium-grained. Interbedded phyllite, brownish-red to brown. Unit poorly exposed. Contact with overlying Batatal Formation gradational. Phyllite, brownish-red, silty, poorly exposed ............. Quartzite, light-gray, fine- to medium-grained, laminated. Some grains of smoky quartz

Phyllite, brownish-red and light-brown, silty. Few thin beds and lenses of gray quartzite

Phyllite, greenish-gray to brownish-gray. Abundant quartz grains and muscovite flakes. Trace limonite stain

Silty phyllite and phyllite, light-brown, gray, and

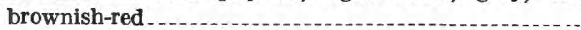

Silty phyllite, light-brown and brownish-red. Few thin beds hard gray quartzite

Quartzite, brownish-red at top grading downward into gray, medium grained to very fine grained.........
Quartzite, tan, brownish-red, and gray, very fine grained to fine-grained. Trace muscovite, black opaque heavy minerals, and limonite stain........... Silty phyllite, tan and brownish-red. Few thin beds as much as $5 \mathrm{~cm}$ thick of very fine grained to mediumgrained quartzite Siltstone and phyllite, yellowish-brown and brownish
red. Abundant quartz grains toward base. Trace vite and black opaque heavy minerals .................

Quartzite, buff to pale-reddish-brown, very fine to medium-grained, moderately friable. Few thin beds of brownish-red phyllite and gray to greenish-gray quartz-

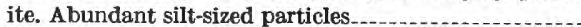

Quartzite, buff, fine- to medium-grained, slightly metamorphosed; contains abundant feldspar porphyroblasts. Contact with underlying Souza Noschese Gneiss gradational . $\begin{array}{lll}0 & 1.3\end{array}$

1.3

$6.7 \quad 7.1$

$7.1 \quad 12.9$

$12.9 \quad 14.2$

15.420 .3

20.320 .5

$20.5 \quad 21.3$

21. $3 \quad 23.2$

$23.2 \quad 24.6$

$24.6 \quad 28.7$

$28.8 \quad 36.2$
$14.2 \quad 15.4$

The Batatal Formation seems to have a constant thickness of about 30 meters across the entire area. However, south of the Candu mine and on the south side of Pico dos Tres Irmãos the formation is folded and its apparent thickness is several times greater than the true thickness. The only completely exposed Batatal section is in the roadcut on the east side of the Rio Paraopeba water gap through the Serra do Curral (pl. 1). The following section was measured there.

Section of the Batatal Formation measured in a roadcut on the east side of the Rio Paraopeba water gap through the Serra do Curral

[Section given from top to base; thicknesses in meters]

\begin{tabular}{|c|c|c|c|}
\hline Description & Top & Base & $\begin{array}{l}\text { Thick- } \\
\text { ness }\end{array}$ \\
\hline $\begin{array}{l}\text { Phyllite, variegated gray, purplish-red, yellowish-brown, } \\
\text { and brownish-red. Few thin layers of itabirite in upper } \\
\text { meter. Grades into overlying Caue Itabirite. }\end{array}$ & 0 & 10.6 & 10.6 \\
\hline Phyllite, very dark brown. Trace carbonaceous material. & & & \\
\hline Abundant limonite stain on bedding planes-a........... & 10.6 & 16.0 & 5.4 \\
\hline black bands. & 16. 0 & 17.5 & 1.5 \\
\hline $\begin{array}{l}\text { Phyllite, alternating brown and purplish-red bands. Trace } \\
\text { carbonaceous material }\end{array}$ & 17.5 & 23.0 & 5.5 \\
\hline Phyllite, dark gray. Abundant carbonaceous material... & 23.0 & 23.3 & .3 \\
\hline $\begin{array}{l}\text { Phyllite, brownish-red. Poorly exposed. Contact with } \\
\text { underlying Moeda Formation gradational. }\end{array}$ & 23.3 & 28.4 & 5.1 \\
\hline
\end{tabular}

The Itabira Group is economically the most important group of rocks in the Quadrilátero Ferrifero. It consists of two formations, the Cauê Itabirite (lower) that contains most of the high-grade iron deposits and some gold deposits, and the Gandarela Formation (upper) that is a source of bauxite and manganese. The group includes the principal chemical metasedimentary rocks in the Minas Series and is largely distinguished on that basis from the underlying Caraça and the overlying Piracicaba Groups, which are composed mainly of clastic rocks.

Although both formations of the Itabira Group are composed of itabirite, phyllite, and dolomite, they differ considerably in the proportions of these rocks that they contain. Whereas the Cauê Itabirite is estimated to contain more than 95 percent itabirite, the Gandarela Formation, being chiefly composed of dolomite and phyllite, is estimated to contain only 15 percent itabirite. Itabirite in the Gandarela Formation is present as lenses a few centimeters to several hundred meters long and a few centimeters to many tens of meters thick. The distribution of these lenses is somewhat erratic in the Gandarela; in general the lenses are more abundant and thicker toward the base of the formation, but they may be in any stratigraphic position.

The entire Itabira Group is particularly well exposed in the water gap where the Rio Paraopeba passes 
through the Serra do Curral and along the road parallel to the river course (pl. 1). A detailed section measured there shows the Itabira Group to be 318 meters thick and the Cauê Itabirite and the Gandarela Formation to be 170 and 148 meters thick, respectively. This section, including 115 intervals which average 1.9 meters in thickness, is summarized in table 3 . The Gandarela Formation is atypically represented here by an exceptionally great thickness of itabirite. Unfortunately, dolomite and phyllite, which comprise the larger part of the formation and are poorly exposed throughout the region, make up only a small part of the formation in the well-exposed section.

For convenience in describing the measured section in the field, itabirite was divided into three principal classes based on the relative amounts of hematite. To check the visual field estimates, 18 samples were collected: 3 samples for each of the principal classes in each formation, or a total of 6 samples for each class. All samples within each class were mixed and analyzed by C. M. Pinto of the Departamento Nacional de Produção Mineral with the following results: High class, 64 percent hematite; medium class, 53 percent hematite; low class, 48 percent hematite. A fourth class having a high phyllite content was not analyzed. The weighted average of the 18 samples indicates that itabirite in the measured section contains 54.0 percent hematite (37.8 percent iron).

TABLE 3.-Thickness and percentage of lithologic types in a section of the Itabira Group measured in the Rio Paraopeba water gap through the Serra do Curral

[Thicknesses in meters]

\begin{tabular}{|c|c|c|c|c|c|c|}
\hline \multirow[t]{2}{*}{ Lithologic type } & \multicolumn{2}{|c|}{$\begin{array}{c}\text { Cause } \\
\text { Itabirite }\end{array}$} & \multicolumn{2}{|c|}{$\begin{array}{l}\text { Gandarela } \\
\text { Formation }\end{array}$} & \multicolumn{2}{|c|}{$\begin{array}{l}\text { Itabira } \\
\text { Group }\end{array}$} \\
\hline & Thickness & Percent & Thickness & Percent & $\begin{array}{c}\text { Total } \\
\text { thickness }\end{array}$ & $\begin{array}{l}\text { Average } \\
\text { percent }\end{array}$ \\
\hline High hematite & 39 & 23 & 36 & 24 & 75 & 24 \\
\hline Medium hematite_. & 64 & 37 & 38 & 26 & 102 & 32 \\
\hline Low hematite..... & 66 & 39 & 29 & 20 & 95 & 30 \\
\hline Phyllitic _........ & 1 & 1 & 18 & 12 & 19 & 6 \\
\hline Total & 170 & 100 & 121 & 82 & 291 & 92 \\
\hline Siliceous dolomite & 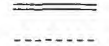 & $=$ & $=$ & $=$ & $=$ & 2 \\
\hline Phyllite & - & - & 21 & 14 & 12 & 6 \\
\hline Grand total..... & 170 & 100 & 148 & 100 & 318 & 100 \\
\hline
\end{tabular}

The Itabira Group is transitional with the underlying Batatal Formation and has an unconformable contact with the overlying Cercadinho Formation of the Piracicaba Group. The group is about 350 meters thick at the east boundary (pl. 1) and 60 meters thick near southwest corner (pl. 3). This difference is considered the result of pre-Cercadinho erosion rather than original deposition. The corresponding outcrop width ranges from 1,300 meters at the east boundary to 125 meters near the southwest corner of the area.
Although no structural difference was observed between the Itabira Group and the Cercadinho Formation, the contact gradually truncates progressively lower parts of the Itabira Group from east to west and is a slight angular unconformity. Thus, the Gandarela Formation becomes thinner westward across the Brumadinho area and disappears 1,400 meters west of the Fêcho do Funil quadrangle boundary (pl. 2). From this point to the southwest corner of the area the unconformity is a contact which cuts gradually into the Caue Itabirite.

\section{CAUÊ ITABIRITE}

The Cauê Itabirite is almost entirely composed of itabirite varieties. It locally contains phyllite lenses in the Brumadinho area and dolomite lenses at other places in the Quadrilátero Ferrifero. Itabirite is more resistant to erosion than all the other Precambrian rocks in the western Serra do Curral. It therefore is better exposed than the other rocks in the region and forms the crest of the Serra do Curral throughout most of its 100-kilometer length.

Pure itabirite is a bimineralic rock containing alternating laminae of hematite and granular quartz (fig. 6). The individual laminae are not pure; a small amount of hematite occurs in the quartz laminae and a small amount of quartz occurs in the hematite laminae. Most of the laminae are between 1 and $5 \mathrm{~mm}$ thick and at many places can be traced for the entire length of an outcrop, 10 meters or more. In this region the grain sizes range from 0.01 to $0.06 \mathrm{~mm}$; quartz grains average $0.04 \mathrm{~mm}$, and hematite grains $0.03 \mathrm{~mm}$. At fresh exposures the itabirite is gray, but on weathered outcrops it is brown as a result of the hydration of hematite to limonite.

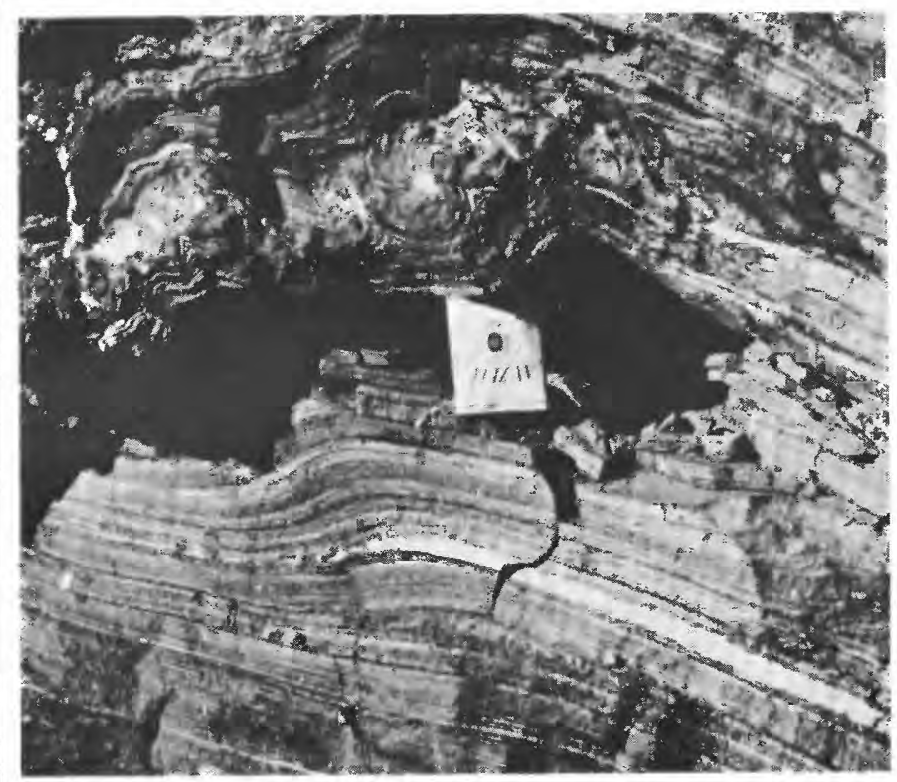

FIGURE 6.-Itabirite from the Caue Itabirite. Hematite-rich laminae, dark; quartz-rich laminae, light. 
There are three main types of itabirite, based on the kind and degree of disaggregation caused by weathering: hard itabirite, soft itabirite, and chapinha. Hard itabirite is characterized by little or no disaggregation of quartz and hematite. Soft itabirite forms where both hematite and quartz disintegrate to sand. Chapinha forms where the quartz layers disaggregate to sand and the hematite breaks into plates. Chapinha is not common in the western Serra do Curral but forms where the hematite occurs as clusters of specularite flakes.

Itabirite has been defined by Dorr and Barbosa (1963, p. 18-19) as follows:

The term itabirite denotes a laminated, metamorphosed, oxide-facies[iron-]formation, in which the original chert or jasper bands have been recrystallized into granular quartz and in which the iron is present as hematite, magnetite, or martite. The quartz bands contain varied but generally minor quantities of iron oxide, the iron-oxide bands may contain varied but generally minor quanti ties of quartz. The term should not include quartzite of clastic origin with iron-oxide cement even though such rocks are som etimes grossly banded. It should include only rocks in which the quartz is megascopically recognizable as crystalline, in order to differentiate it from unmetamorphosed oxide-facies iron-formation. A certain amount of impurity in the form of dolomite or calcite, clay, and the metamorphic minerals derived from these materials may be included, but these may never be dominant constituents over any notable thickness. Where they are, the rock term must be qualified by the use of the appropriate mineral name as a qualifier (for example, dolomitic itabirite, a rock in which the dolomite largely takes the place of the quartz). Rarely itabirite grades into ferruginous chert which, when recrystallized, may look like low-grade itabirite, although commonly it is finer grained and whiter. To prevent confusion, a cutoff point of about 25 percent iron should be established. This figure is a practical one, as few itabirites are so lean in iron and most ferruginous cherts do not contain so much iron. Itabirite may grade into pure hematite through enrichment in iron or removal of quartz: the cutoff point might well be set at 66 percent iron because at and above this grade quartz is rarely concentrated in regular laminae.

Twenty analyses of itabirite from the Cauê Itabirite in the western Serra do Curral, included in the results of chemical analyses of iron minerals published by Pimentel de Godoy (1957, p. 105-107), are given in table 4. The average of these figures is: $\mathrm{Fe}, 46.97$ percent; $\mathrm{SiO}_{2}, 31.63$ percent; $\mathrm{P}, 0.046$ percent. Thus, the rock averages about 67 percent hematite and 32 percent quartz. The high iron (hematite) content suggests that the samples were soft itabirites, ones from which quartz was removed by weathering.

A very hard variety of siliceous itabirite consisting of alternating gray hematite-rich layers and pink quartz-rich layers occurs at several places but is most conspicuous at Pico do Itatiaiuçu (pl. 2) and several nearby unnamed peaks. The pink color results from abundant disseminated hematite in quartz. In thin section the quartz grains show no indication of dis- aggregation. An analysis of a sample of siliceous itabirite from the southwest side of Pico do Itatiaiuçu is given in table 2 (sample 5 ). This rock contains approximately 41 percent hematite and 58 percent quartz.

\begin{tabular}{|c|c|c|c|c|}
\hline \multirow{2}{*}{$\begin{array}{l}\text { Pimentel } \\
\text { de Godoy } \\
\text { Sample }\end{array}$} & \multirow{2}{*}{ Section of Serra do Curral } & \multicolumn{3}{|c|}{ Weight percent } \\
\hline & & $\mathrm{Fe}$ & $\mathrm{SiO}_{2}$ & $\mathrm{P}$ \\
\hline 65 & Tres Irmãos.......... & 50.92 & 21.12 & 0.056 \\
\hline 74 & ....Fecho do Funil... & 39.83 & 42.04 & .044 \\
\hline 75 & .... do & 45.44 & 32. 20 & .055 \\
\hline 78 & ....do do........ & 40.20 & 39. 31 & .065 \\
\hline 79 & ....do.... & 50.76 & 25.99 & .033 \\
\hline 80 & .... do $0_{\ldots} \ldots \ldots$ & 60.74 & 10.46 & .025 \\
\hline 81 & do do & 43.97 & 33.56 & .035 \\
\hline 82 & ....do do........ & 45.63 & 34. 74 & .021 \\
\hline 83 & .... do & 40.50 & 39.55 & .031 \\
\hline 84 & .... do $0 . . . . . . .$. & 47. 36 & 33.04 & .036 \\
\hline 98 & Farofas & 40.80 & 40.34 & .057 \\
\hline 99 & .....do......... & 42.60 & 38. 26 & .032 \\
\hline 101 & do & 44. 40 & 33. 38 & .02 \\
\hline 102 & Mantiqueira & 45. 52 & 33. 06 & .026 \\
\hline 108 & Itatiaia & 52.34 & 23. 48 & .04 \\
\hline 109 & Azul & 41. 46 & 39. 91 & .108 \\
\hline 111 & ...do-_. & 50.52 & 26. 12 & .39 \\
\hline 114 & do & 42. 90 & 38.14 & \\
\hline 118 & ...do do & 51.72 & 23.5 & .077 \\
\hline 119 & -do-dond & 61.71 & 24. 38 & .072 \\
\hline $\begin{array}{l}\text { A ver- } \\
\text { age_- }\end{array}$ & & 46.97 & 31.63 & .046 \\
\hline
\end{tabular}

Besides biminerallic itabirite, the Cauê Itabirite contains several other varieties of itabirite in the western Serra do Curral, including tremolitic, dolomitic and phyllitic itabirite. Tremolitic itabirite typically consists of thin alternating layers of hematite and reticulated and radiating limonite. The limonite is pseudomorphous after tremolite or a similar mineral, and some limonite has also been formed in the hematite layers by the hydration of that mineral. Fresh amphibole was found in a roadcut in the Rio Paraopeba water gap through the Serra do Curral. It was identified by Herz (written commun., 1961) as cummingtonite, a variety of amphibole which contains 60 percent grunnerite and 40 percent kupferite. An analysis of this sample is given in table 2 (sample 6). Tremolite was identified in another itabirite (table 2, sample 7) (written commun., 1962) from a small pit along the road where the Ribeirão Retirodos Pintos cuts through the Serra do Curral at the west extremity of the area (pl. 3).

Tremolitic itabirite is more abundant in the western Serra do Curral than elsewhere in the Quadrilatero Ferrifero and is particularly abundant from the Candu mine east to the Ibirite quadrangle (pl. 1). This zone of abundant tremolitic itabirite overlies the Caraça Group where that unit is thin. The zone indicates the 
possibility of a different local sedimentation environment in the Brumadinho area that resulted in the deposition of magnesian, calcic, and aluminous "impurities" in the original iron-formation.

Fresh dolomitic itabirite was seen in only a few thin beds in the Rio Paraopeba water gap through the Serra do Curral. Some weathered, ocherous itabirite containing small magnetite crystals is undoubtedly derived from this rock. Dolomitic itabirite differs from biminerallic itabirite in that dolomite occurs at the partial expense of quartz so that quartz-dolomite-rich layers alternate with iron-rich layers. The iron-rich layers differ from biminerallic itabirite in that they contain magnetite in addition to hematite.

Phyllitic itabirite is probably common in the Brumadinho area but, being less resistent to weathering than other kinds of itabirite, is well exposed only in mine workings. At the Candú mine a complete gradation of lithologic types from phyllitic itabirite to ferruginous phyllite are exposed. Where present in small quantity, the phyllite forms thin laminae in itabirite. Larger quantities of phyllite occur more at the expense of quartz than of hematite, and where ferruginous phyllite is present, quartz is a minor constituent.

\section{CaUÊ-GaNDARELA CONTACT}

At many places in the Quadrilatero Ferrifero the Cauê Itabirite and the Gandarela Formation are intergradational. As previously mentioned, both contain the same lithologic types, and the principal difference between the two formations is higher concentration of itabirite in the Cauê Itabirite and a higher concentration of phyllite and dolomite in the Gandarela Formation. The contact between the two formations is irregular and at different horizons from place to place, varying radically within short distances. Thus, the Cauê Itabirite and the Gandarela Formation might more reasonably be considered as members of one formation. However, their formation status as used herein conforms to the terminology used throughout the Quadrilátero Ferrifero. The contact between the two formations on the geologic maps (pls. 1,2) has been in part drawn on the basis of topography because of (1) the generally low degree of resistance to erosion offered by the Gandarela Formation and the consequent lack of outcrops, and (2) the wide zone of gradation between the formations.

\section{GANDARELA FORMATION}

The Gandarela Formation consists mostly of dolomite and phyllite but also contains the several itabirite varieties, with the exception of the very hard itabirite containing pink quartz laminae previously described under the Caue Itabirite. The formation is very poorly exposed in the western Serra do Curral and, except where it contains itabirite or siliceous dolomite lenses, weathers to a depressed terrain between the Cauê Itabirite and the Cercadinho Formation. In contrast, it is better exposed in the central part of the Serra do Curral, where it was studied in detail by Pomerene (1964, p. 15-20).

Dolomites of the Gandarela Formation are white, gray, and red, fine to medium grained, and commonly siliceous. Dolomite beds weather to "splash rock," an informal name given by Pomerene (1964, p. 19). "Splash rock" has been described by Guild (1957, p. 42) as follows:

If struck with a pick, the point sinks in to the shaft almost without resistance, and muddy water spurts out with considerable force. (This has led to the useful, if informal, name of "splash rock" for the material.) A small fragment feels almost dry to the touch, and can easily be cut to any desired shape with a pen knife. If squeezed between the thumb and forefinger, it resists pressure for a moment without any of the plasticity of a clay, then collapses suddenly to a little muddy water that has a faintly gritty feel.

The best exposures of dolomite are at the small Bocaina quarry prospect (pl. 1, N. 7,400, E. 400), where an adit penetrates the dolomite for 14 meters before entering "splash rock." At the time this area was mapped the 14-meter adit was marked at six places with chemical analyses of the dolomite. An average of these six samples is listed in table 2 (sample 8 ). Another dolomite lens crops out at the base of Pico dos Tres Irmãos on its north side (pl. 1, N. 10,000, E. 11,300). Analyses of two samples from this lens are listed in table 2 (samples 9 and 10).

Phyllite undoubtedly makes up a large part of the Gandarela Formation but is the most poorly exposed rock in the formation. The most extensive, but poor, exposures are north of the Bocaina iron-mining properties (pl. 1, N. 10,500, E. 8,600). There the weathered phyllite is various shades of brown and red; some phyllite is is ferruginous and some, before weathering, probably contained dolomite.

\section{PIRACICABA GROUP}

The Piracicaba Group contains five formations which, from oldest to youngest, are the Cercadinho Formation, Fêcho do Funil Formation, Taboões Quartzite, Barreiro Formation, and Sabará Formation. The formations are thicker and better exposed on the north side of the Serra do Curral than in any other part of the Quadrilatero Ferrífero; all five type localities are there. With the exception of the Sabara Formation, the formations are relatively well exposed in the western Serra do Curral.

The Piracicaba Group crops out in a band that thins across the western Serra do Curral area from 
4,500 meters wide in the east to 30 meters wide in the west. The north margin of this band, bounded by gneiss, crosses the width of the area shown on plate 3 and most of plate 2 but lies a few hundred meters north of the area shown on plate 1 . The thinning of the outcrop band corresponds to a similar thinning of the group from 600 to 20 meters. In both the group and the outcrop, the thinning results chiefly from truncation by gneiss. The overall thinning is effected to a lesser extent by the "pinchout" of the Barreiro Formation and stratigraphic thinning of the Fêcho do Funil Formation, the Tabozes Quartzite, and possibly the Sabará Formation.

\section{CERCADINHO FORMATION}

The Cercadinho Formation contains several distinctive lithologic types and is well exposed in many places. Despite the fact that all individual units are lenticular, the formation as a whole is one of the more useful mapping units over much of the Quadrilátero Ferrífero. The formation in the western Serra do Curral is composed principally of ferruginous quartzite and conglomerate (40 percent), ferruginous phyllite ( 40 percent), and dolomitic phyllite (20 percent) most of which has weathered to "splash rock." Most conglomerate occurs in the lower part of the formation, and most dolomitic phyllite in the middle and upper parts of the formation. Thus the formation is generally more arenaceous toward its base and more phyllitic toward the top.

Two varieties of conglomerate are present: pebble conglomerate and granule conglomerate. The lowest beds in the formation are commonly conglomeratic in the West End area and include most of the pebble conglomerates. Most conglomerates are gray, but some are various shades of brownish red. The pebbles are of white quartzite and are subangular to round, and most are $1 \mathrm{~cm}$ or less in diameter, al though some larger than $4 \mathrm{~cm}$ were found. The pebbles are set in a matrix of poorly sorted quartz grains and hematite flakes.

The granule conglomerates are most abundant in the lower part of the formation and occur as lenses in quartzite. At many places the granules in these conglomerates were deformed into spindles resembling grains of rice. The field term "rice grit" has been used for these rocks (Pomerene, 1964, p. 23).

Most quartzite is gray or tan, is poorly sorted, and may have argillaceous partings; it contains specularite flakes disseminated throughout the rock and in some places the flakes form layers. Where hematite is concentrated in layers, the quartzite may have a superficial resemblance to itabirite. Fine flakes of white mica are also abundant. Small-scale crossbedding and scour-andfill structures are common features. A chemical analysis of a sample of fresh ferruginous quartzite, taken from a roadcut on the road leading north from the Bocaina mine area (pl. 1, N. 10,000, E. 9,800), is given in table 2 (sample 11).

Much of the phyllite has a distinctive lustrous silvery-gray color which results from disseminated microscopic flakes of hematite. In many beds, especially in the lower part of the formation, hematite is abundant enough that the phyllite yields a red streak, even though hematite grains cannot be seen without a hand lens. The field terms "silver phyllite" and "silver schist" have of ten been used in describing this rock. In thin sections the phyllites are seen to consist mostly of sericite and abundant quartz and hematite.

Brown and gray phyllite is interbedded with silverygray phyllite in the upper part of the formation; as seen in thin section the phyllite consists of sericite, quartz, and minor hematite. The former presence of dolomite is indicated by black and brown manganese oxide stain in the phyllite and by the presence of "splash rock."

The base of the Cercadinho Formation unconformably overlies the Itabira Group and is in contact with the Cauê Itabirite in the west and with the Gandarela Formation in the east. The upper part of the formation is transitional with the Fêcho do Funil Formation except where the latter formation is faulted out or incorporated into gneiss toward the west end of the Serra do Curral.

The Cercadinho Formation ranges in thickness from 80 to 120 meters where the entire formation is present. The variation is irregular and appears unrelated to the general westward thinning of other formations in the Piracicaba Group. However, at the west end of the Serra do Curral, all but the basal 30 meters of the formation has been faulted out or incorporated into gneiss. Two complete sections of the Cercadinho Formation were measured in the Brumadinho area-one in roadcuts on the east side of the Rio Paraopeba opposite the community of Fêcho do Funil (pl. 1), and the other along an abandoned tramline cut between the Candú mine and Fêcho do Funil (pl. 1). A comparison of the two sections indicates lateral variation, lenticularity, and lack of continuity of individual beds.

\begin{tabular}{|c|c|c|c|}
\hline \multicolumn{4}{|c|}{$\begin{array}{l}\text { Measured section of the Cercadinho Formation along } \\
\text { east side of Rio Paraopeba, opposite community of } \\
\text { Funil } \\
\text { [Section given from top to base; thicknesses in meters] }\end{array}$} \\
\hline Description & Top & Base & Thickness \\
\hline \multicolumn{4}{|l|}{$\begin{array}{l}\text { Quartzite, pale bluish-gray, very fine grained. Sparse } \\
\text { flakes specularite. Contact with overlying Fecho do } \\
\text { Funil Formation gradational }\end{array}$} \\
\hline Phyllite, silvery-gray & .9 & 10. 1 & 9.2 \\
\hline $\begin{array}{l}\text { Quartzite, pale bluish-gray, very fine grained. Traces of a } \\
\text { dark-green acicular transparent mineral (tourmaline?), } \\
\text { and flakes specularite and sericite. }\end{array}$ & 10.1 & 10.3 & \\
\hline $\begin{array}{l}\text { "Splash rock," black. Trace bluish-gray phyll } \\
\text { for manganese, } 1.7 \text { percent. }\end{array}$ & 10.3 & 24.5 & 14. 2 \\
\hline
\end{tabular}


Measured section of the Cercadinho Formation along road on east side of Rio Paraopeba, opposite community of Fêcho do Funil-Continued

\begin{tabular}{|c|c|c|c|}
\hline Description & Top & Base & Thickness \\
\hline Phyllite, bluish-gray, and black "splash rock" & 24.5 & 25.2 & 0.7 \\
\hline “Splash rock,” black. & 25.2 & 25. 7 & .5 \\
\hline Phyllite, bluish-gray & 25. 7 & 31.3 & 5.6 \\
\hline "Splash rock," black. Trace bluish-gray phyllite & 31.3 & 33.4 & 2.1 \\
\hline Phyllite, bluish-gray & 33.4 & 34.8 & 1.4 \\
\hline "Splash rock," brown and black & 34.8 & 37.6 & 2.8 \\
\hline $\begin{array}{l}\text { Quartzite and phyllite, bluish-gray. Sparse fiakes specu- } \\
\text { larite }\end{array}$ & 37.6 & 390 & 14 \\
\hline “Splash rock," black. & 37.0 & $\begin{array}{l}39.0 \\
42.2\end{array}$ & $\begin{array}{l}1.4 \\
3.2\end{array}$ \\
\hline Phyllite, bluish-gray & 42.2 & 44.7 & 2.5 \\
\hline $\begin{array}{l}\text { Quartzite, bluish-gray, very fine grained. Abundant } \\
\text { specularite fiakes. . . } \\
\text { "Splash rock," yellowish-brown. Trace silvery-gray phyl- }\end{array}$ & 44. 7 & 45.8 & 1. 1 \\
\hline lite & 45.8 & 48. 3 & 2.5 \\
\hline $\begin{array}{l}\text { Quartzite, dark bluish-gray, very fine grained. Abundant } \\
\text { specularite flakes. }\end{array}$ & 48. 3 & 49.1 & .8 \\
\hline $\begin{array}{l}\text { Phyllite, bluish-gray, and yellow and black "splash } \\
\text { rock"- }\end{array}$ & 49.1 & 50. 2 & 1. 1 \\
\hline $\begin{array}{l}\text { Quartzite, gray, very fine grained. Trace specularite flakes. } \\
\text { Phyllite, bluish- to silvery-gray: numerous spots of yel- } \\
\text { ish-brown and black "splash" rock. Upper } 0.4 \text { meter }\end{array}$ & 50.2 & 50.6 & .4 \\
\hline $\begin{array}{l}\text { arenaceous } \\
\text { Phyllite, bluish-gray. Arenaceous, slightly resistant. }\end{array}$ & 50.6 & 58.8 & 8.2 \\
\hline $\begin{array}{l}\text { Trace sericite } \\
\text { Phyllite, silvery- to bluish-grav; abundant specularite }\end{array}$ & 58.8 & 60.9 & 2.1 \\
\hline $\begin{array}{l}\text { Thyilue, silvery- to bluish-gray; abundant specularite } \\
\text { flakes }\end{array}$ & 60.9 & 63.4 & 2.5 \\
\hline Covered. & 63.4 & 66.0 & 2.6 \\
\hline $\begin{array}{l}\text { Phyllite, gray to brown, silty. Trace silvery gray phyllite. } \\
\text { Abundant manganese oxide stain }\end{array}$ & 66. 0 & 75.5 & 9. 5 \\
\hline $\begin{array}{l}\text { Phyllite, bluish-, silvery-, and light-greenish-gray. Abun- } \\
\text { dant flakes of specularite, silt-sized quartz grains, and } \\
\text { sericite. Weakly foliated.....-..-.-. }\end{array}$ & 75.5 & 78.8 & 3.3 \\
\hline $\begin{array}{l}\text { Phyllite, silvery-gray. Abundant specularite in lower } \\
\text { part, A bundant sericite. }\end{array}$ & 78.8 & 81.9 & 3.1 \\
\hline $\begin{array}{l}\text { Quartzite, gray, very flne grained. Abundant flakes of } \\
\text { specularite.- }\end{array}$ & 81.9 & 82.9 & 1.0 \\
\hline Phyllite, gray, quartzitic. Very abundant flakes of specu- & & & \\
\hline larite. Local limonite stain. Abundant sericite.......... & 82.9 & 85.4 & 2.5 \\
\hline Phyllite, gray. Poorly exposed & 85.4 & 87.9 & 2.5 \\
\hline $\begin{array}{l}\text { Covered in line of section; position occupied by quartzite } \\
20 \text { meters upslope. Location of contact with Gandarela }\end{array}$ & & & \\
\hline Formation estimated & 87.9 & 97.9 & 10.0 \\
\hline
\end{tabular}

Measured section of the Cercadinho Formation in tramline cut between Fêcho do Funil and Candú mine area

[Section given from top to base; thicknesses in meters]

Description

Covered, probably phyllite. Position of contact with the overlying Fêcho do Funil Formation estimated Quartzite, dark-gray to tan, very fine grained, abundant flakes specularite. Friable .............................. Phyllite, dark-gray. Abundant specularite fla kes......... Quartzite, dark-gray, very fine grained; interbedded with dark-gray phyllite. A bundant specularite flakes.. Quartzite, dark-gray, very fine grained, crossbedded. Abundant specularite flakes.

Quartzite, gray, fine-grained; interbedded with darkgray phyllite. A bundant specularite flakes .............. Quartzite, gray to tan, fine-grained. Few thin beds of gray phyllite.

Quartzite, dark-gray; fine grained at top, grading downward into granule conglomerate at base. Abundant specularite. Crossbedded..............................

Phyllite, gray. Numerous thin beds of crossbedded quartzite

Quartzite, gray, fine-grained to granule conglomerate. Few thin layers of gray phyllite. Crossbedded......... Phyllite, gray. Numerous thin beds of fine-grained gray quartzite.

Top Base Thickness

\section{0}

5.014 .3

$14.3 \quad 15.9$

15. 922.1

$22.1 \quad 26.7$

$26.7 \quad 32.8$

$32.8 \quad 36.0$

$36.0 \quad 37.0$

$37.0 \quad 41.6$

$41.6 \quad 50.8$

$50.8 \quad 63.0$
Measured section of the Cercadinho Formation in tramline cut between Fêcho do Funil and Candí mine area-Continued

$$
\text { Description }
$$

Top Base Thickness

Quartzite, gray, fine-grained, crossbedded. Few thin layers of gray phyllite.......................................

Phyllite, gray; interbedded with fine-grained gray quartzite. Abundant flakes specular hematite. Beds range in thickness from 3 to $30 \mathrm{~cm}$

Phyllite, silvery-gray.

Phyllite, silvery gray at top grading downward into silty gray and olive-green phyllite.....................Quartzite, gray to tan, fine-grained to granule conglomerate; interbedded with gray to olive-green phyllite...... Phyllite, silvery-gray Phyllite; silvery gray at top grading downward into silty gray and olive-green phyllite................................ Quartzite, gray to tan, fine-grained to granule conglomerate; interbedded with gray to olive phyllite............-. Quartzite, gray to tan, fine-grained. Few lenses of granule conglomerate. Conglomerate lenses contain interstitial argillaceous material and are slightly friable............. Quartzite, gray to tan, fine-grained to granule conglomer-

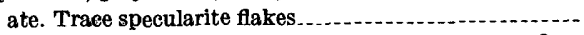
Quartzite, gray with few streaks of reddish brown, fineto medium-grained, friable. Abundant interstitial argillaceous material. Trace specular hematite flakes.Quartzite, gray, very fine grained, hard, crossbedded.

Trace specular hematite flakes.

Quartzite, tan to gray, fine- to coarse-grained. Few lenses of granule conglomerate. Abundant gray argillaceous partings. Quartzite, gray, fine-grained to granule conglomerate. percent specularite flakes. Few argillaceous partings. Contact with underlying Gandarela Formation disconformable.

\begin{tabular}{llll}
63.0 & 70.0 & 7.0 \\
\hline 70.0 & 72.1 & 2.1 \\
72.1 & 73.8 & 1.7 \\
\hline 73.8 & 76.7 & 2.9 \\
\hline 76.7 & 78.8 & 2.1 \\
72.1 & 73.8 & 1.7 \\
\hline 73.8 & 76.7 & 2.9 \\
\hline 76.7 & 78.8 & 2.1 \\
& & \\
\hline 78.8 & 83.7 & 4.9 \\
\hline 83.7 & 84.3 & .6 \\
\hline 84.3 & 85.0 & .7 \\
\hline 85.0 & 85.7 & .7 \\
\hline 85.7 & 91.8 & 6.1 \\
\hline & & \\
\hline
\end{tabular}

$91.8 \quad 94.8$

\section{FÊCHO DO FUNIL FORMATION}

The Fêcho do Funil Formation is composed of phyllite, siltstone, and dolomite. Because the formation weathers easily, it forms low areas between the more resistant and topographically higher Cercadinho Formation and Taboões Quartzite. Natural outcrops are scarce, and most exposures are in ditches and roadcuts.

Phyllite is grayish green, gray, tan, brown, and brownish red, and many beds are silty and dolomitic; siltstone is gray to dark brown and is dolomitic and phyllitic; siliceous dolomite is gray and pink. Beds of silvery-gray ferruginous phyllite occur near the base of the formation. Dolomite is more abundant in the upper part of the formation, and phyllite is more abundant in the lower part. The different lithologies occur in thicknesses of a few centimeters to several tens of meters.

With few exceptions, all beds are composed of differing amounts of the same constituents. In order of abundance of rock types and abundance of constituents these are: Phyllite composed of sericite, quartz, and dolomite; siltstone composed of quartz, sericite, and dolomite; and dolomite composed of dolomite, quartz, and sericite. Dolomite has been 2 leached from many rocks. Where this has occurred the phyllites have weathered to "splash rock," and the 
siltstones to a very light porous rock in which manganese oxide forms a thin coating on the inside of many of the pore spaces. All dolomite beds are highly siliceous; in thin section they contain a minimum of about 30 percent quartz. A fresh dolomite sample from a railroad cut 1 kilometer north of Fêcho do Funil contained 40 percent $\mathrm{SiO}_{2}$ (table 2, sample 12).

The silvery-gray phyllite is identical with some of the silvery-gray phyllite in the Cercadinho Formation. Although the content of detrital hematite in this rock is not enough to give a red streak when scratched, numerous small flakes were seen in thin sections examined under the microscope.

The formation is thickest near the community of Fêcho do Funil and thins to both the east and the west from that area. At the east boundary of the mapped area it is about 200 meters thick, and in the West End area it thins to about 100 meters before being truncated by gneiss.

The type locality of the Fêcho do Funil Formation is in railroad and highway cuts near Fêcho do Funil. The formation was named before the type section was measured (Simmons, 1958); although it was originally estimated at 600 meters, measurement indicates it to be 410 meters thick at the type locality. (See measured section.)

As originally defined, the base of the formation was placed so that "all thick ferruginous quartzite beds and all zones of one or more meters thick, which contain more ferruginous quartzite than other constituents, are excluded from the Fêcho do Funil formation" (Simmons, 1958, p. 65). The author here adopts the proposal of Pomerene (1958a, p. 65) that all beds of ferruginous quartzite be placed in the underlying Cercadinho Formation. This redefinition accounts for part of the difference between the originally estimated and subsequently measured thicknesses.

Composite section of the Fêcho do Funil Formation measured in railroad cut half a kilometer north of Fêcho do Funil and in roadcut on the east side of Rio Paraopeba, opposite Fêcho do Funil

[Section given from top to base; thicknesses in meters]

Description

Top Base Thickness

Dolomite, gray. Very abundant grains of silt-sized quartz. A bundant thin argillaceous layers. Trace stains of limonite and manganese oxide. Gradational contact with argillaceous and dolomitic quartzite at base of the

Taboões Quartzite

Dolomite, gray. Numerous argillaceous laminae. Few arenaceous layers near top. Numerous black heavy opaque minerals.

Siltstone, brown, dolomitic and phyllitic. Porous; abundant manganese oxide stain .......................................

Dolomite, gray to pink

Siltstone, brown, dolomitic and phyllitic. Porous; abundant manganese oxide stain

Dolomite, gray, silty ..............

Siltstone, light-brown to gray, phyllitic, finely lamimated.

\begin{tabular}{rr}
.9 & 4.2 \\
4.2 & 6.1 \\
6.1 & 9.0 \\
& \\
9.0 & 10.9 \\
10.9 & 11.4 \\
\hline 11.4 & 15.7
\end{tabular}
3.
Composite section of the Fêcho do Funil Formation measured in railroad cut half a kilometer north of Fêcho do Funil and in roadcut on the east side of Rio Paraopeba, opposite Fêcho do Funil-Continued

\section{Description}

Top Base Thickness

Phyllite, light-gray, arenaceous. A bundant flakes of spec-

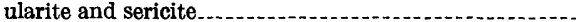

Phyllite and siltstone, light- to dark-brown, dolomitic. Trace pink dolomite. Few thin laminae grayish-green

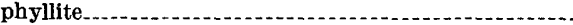

Dolomite, silvery-gray to gray and brown, silty and phyllitic. Dolomite mostly leached from brown areas. Abundant black opaque heavy minerals, specularite and sericite. Some phyllitic layers as much as 0.2 meter thick. Trace manganese oxide............................. Phyllite, brown, silty. Very poorly exposed................ Phyllite, light-gray, silty, dolomitic. Weathering to brown silty punky phyllite, without dolomite.... Siltstone, grayish-brown, phyllitic. Numerous black opaque heavy minerals; punky, poorly exposed......

Siltstone, brown, phyllitic, dolomitic, punky. Porous; abundant manganese oxide stain. Numerous black opaque heavy minerals. ...................................

Siltstone, light-gray, dolomitic, phyllitic .................

Siltstone, brown, tan, and gray, phyllitic, punky, dolomitic. A few banded zones of limonite and manganese oxide stain Phyllite, gray, dolomitic
Siltstone, brown to gray, phyllitic, dolomitic, punky. Numerous black opaque heavy minerals. Local limonite and manganese oxide stained layers and irregular spots . - . 15. $7 \quad 18.6$ $\begin{array}{lll}18.6 & 57.3 & 38.7\end{array}$

[Measured section offset from railroad cuts on west side of river to lower part of section in roadcuts on east side of river.]

"Splash rock," black, and grayish-green phyllite. Very poorly exposed............................................

"Splash rock," black, and grayish-green phyllite..........

Phyllite, brownish-red and grayish-green. Manganese oxide stain on bedding planes.

Alternating zones of "splash rock," black, and brownish-

red and greenish-gray dolomitic phyllite................

Phyllite, brownish-red and dusky-green, silty ..............

Phyllite, $\tan$ to grayish-green and brownish-red. Lower

3.4 meters poorly exposed

Phyllite, silvery-gray. Abundant black and brown

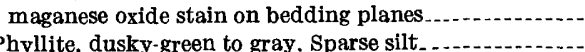

Phyllite, dusky-green to gray, Sparse silt. ................

unweathered blocks of high dolomite content. .........

"Splash rock," black with some orangish-brown splotches. Few blocks of slightly weathered siliceous gray and pink

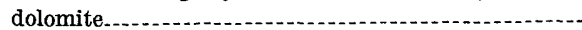

"Splash rock," brown. Trace gray phyllite. Poorly "Splash rock," brown. Trace gray phyllite. Poorly
exposed. Position of contact with underlying Cerca-

dinho Formation estimated wath underlying Cerca-

$\begin{array}{lll}57.3 & 75.3 & 18.0\end{array}$

$\begin{array}{lll}75.3 & 81.8 & 6.5\end{array}$

$\begin{array}{lll}81.8 & 87.1 & 5.3\end{array}$

$87.1 \quad 136.0 \quad 48.9$

136. $0 \quad 142.1 \quad 6.1$

$142.1 \quad 143.5 \quad 1.4$

$143.5 \quad 155.3 \quad 11.8$

$155.3 \quad 155.8 \quad .5$

$155.8 \quad 174.0$

\begin{tabular}{rrr}
174.0 & 196.0 & 22.0 \\
196.0 & 199.6 & 3.6 \\
199.6 & 200.9 & 1.3 \\
& & \\
200.9 & 204.4 & 3.5 \\
204.4 & 222.9 & 18.5 \\
& & \\
222.9 & 231.8 & 8.9 \\
231.8 & 240.7 & 8.9 \\
& & \\
240.7 & 244.1 & 3.4 \\
244.1 & 257.2 & 13.1 \\
& & \\
257.2 & 262.1 & 4.9 \\
& & \\
& & \\
262.1 & 293.6 & 31.5 \\
293.6 & 382.9 & 89.3 \\
& & \\
382.9 & 411.1 & 28.2 \\
\hline
\end{tabular}

The upper contact of the Fêcho do Funil Formation with the Taboões Quartzite remains unchanged. The formations are transitional within 3 meters or less, and the contact is arbitrarily placed so that all phyllite beds are included in the Fêcho do Funil Formation.

The Taboões Quartzite is composed almost entirely of quartzite. As the quartzite is more resistant to weathering than the adjacent formations, it forms a low ridge on the north side of the Serra do Curral for much 
of the length of the range. The Taboões Quartzite is also better exposed than the adjoining formations and, being relatively thin, is a useful mapping unit. In the eastern part of the Brumadinho area (pl. 1, N. 11,600, E. 11,400 ), the quartzite is locally disaggregated and is eroded along the strike by steep-sided gullies. The gullies are as distinctive as the quartzite ridges and are equally useful in tracing the formation.

The formation is composed of quartzite except for the basal few meters that contain argillaceous, silty, and dolomitic layers and the upper few meters that contain carbonaceous phyllite layers. The quartzite is white to tan, very fine grained, massive, and friable; bedding is present ouly in the upper and lower few meters. The quartzite is composed almost entirely of quartz but contains traces of sericite, specularite, and black opaque heavy minerals, The quartz grains are well rounded, etched, and of nearly the same size, ranging from 0.04 to $0.06 \mathrm{~mm}$ in diameter; grains as much as $0.2 \mathrm{~mm}$ in diameter are sparsely disseminated throughout the rock. At many places the quartzite contains minute cavities stained with limonite, possibly derived from the weathering of hematite and pyrite. Taboões Quartzite from its freshest known occurrence in a railroad cut, 0.8 kilometer north of Fêcho do Funil, was analyzed and found to contain 98.5 percent $\mathrm{SiO}_{2}$ (table 2, sample 13).

The Taboones Quartzite grades into the underlying Fêcho do Funil Formation within a few meters. In the east half of the area it grades into the overlying Barreiro Formation within less than one to several meters. To the west, where the Barreiro Formation is missing, the Taboões Quartzite is in contact with the Sabará Formation. The reasons for considering this contact a disconformity are discussed in the section describing the Sabará Formation.

The Taboões Quartzite ranges in thickness from about 100 meters in the east to 30 meters in the west where it is truncated by gneiss. This variation in thickness may be partly the result of pre-Sabara erosion in the west, but the general trend in thickness where the formation is overlain by the Barreiro Formation also indicates a westward thinning. Two sections measured near Fêcho do Funil show a local variation in thickness between 60 and 75 meters. The thicker of these is given in the following section.

Measured section of Taboóes Quartzite in railroad cut about 0.8 kilometer north of Fêcho do Funil on the west side of the Rio Paraopeba

[Section given from top to base; thickness in meters]

Description

Top Base Thickness

Quartzite, white, very fine grained, friable. Poorly exposed. Upper 1.5 meters contains thin layers of carbonaceous phyllite..
Measured section of Taboões Quartzite in railroad cut about 0.8 kilometer north of Fêcho do Funil on the west side of the Rio Paraopeba-Continued

Description Top Base Thickness

Quartzite, white to tan, very fine grained, massive. Few

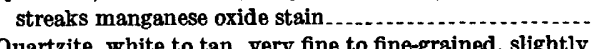
Quartzite, white to tan, very fine to fine-grained, slightly friable, massive. Slightly porous; minute vugs lined with limonite. Trace black opaque minerals and sericite. Quartzite, gray to tan, fine grained, massive. Trace specu-

larite, pyrite, sericite, and limonite ..................... Quartzite, poorly exposed........................................ Quartzite, light-brown, very fine grained, punky. Few thin argillaceous and dolomitic layers. Crossbedded. Transition zone between Taboões Quartzite and under-

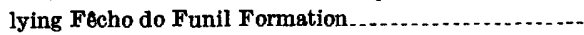

$29.5 \quad 35.9$ 6. 4 $\begin{array}{lll}35.9 & 64.9 & 29.0\end{array}$ $64.9 \quad 66.0 \quad 1.1$ 66. $069.1 \quad 3.1$

$69.1 \quad 73.4 \quad 4.3$

\section{BARREIRO FORMATION}

The Barreiro Formation consists entirely of phyllite and is poorly exposed. Despite its susceptibility to weathering, the formation can usually be mapped without difficulty because it is next to the more resistant underlying Taboões Quartzite and because it weathers to a dark-gray soil that is useful in determining the location of the contact with the overlying Sabará Formation.

Most of the Barreiro Formation is dark-gray carbonaceous phyllite which is interbedded with darkpurplish-red phyllite and brown phyllite. The best exposures of the formation are on the Brumadinho-Belo Horizonte road (pl. 1, N. 11,500, E. 4,300). Carbonaceous phyllite from the type locality of the Barreiro Formation in the adjacent Ibirite quadrangle (Pomerene, 1964, p. 26) was analyzed by I. A. Breger (written commun., 1962) to determine whether or not it contained organic material. Insoluble and soluble organic compounds were found to compose 1.5 percent of the rock. The insoluble compounds were determined, on an ash- and moisture-free basis, to be composed of 96.0 percent carbon, 0.4 percent hydrogen, 3.3 percent oxygen, and 0.2 percent nitrogen. Rock probably containing as much carbonaceous material is abundant in the formation in the western Serra do Curral. Another sample of carbonaceous phyllite from the type locality was recently analyzed by rapid rock analysis methods (table 2, sample 14).

The Barreiro Formation grades within a meter into the underlying Taboões Quartzite and has an abrupt contact with the overlying Sabara Formation. The author considers the Barreiro-Sabara contact disconformable. However, Pomerene (1958b; 1964, p. 27) considers the same contact to be gradational to the east in the Ibirité and Belo Horizonte quadrangles. The formation thins from about 40 meters at the east boundary (pl. 1) to an edge in the central part of the area near the Belo Horizonte-São Paulo highway (pl. 2). 
A section 30 meters thick lying 0.7 kilometer north of Fêcho do Funil was measured and is given in the following table.

Measured section of the Barreiro Formation on west side of hill in old washed-out road about 0.7 kilometer north of Fêcho do Funil

[Section given from top to base; thickness in meters]

\begin{tabular}{|c|c|c|c|}
\hline Description & Top & Base & Thickness \\
\hline $\begin{array}{l}\text { Covered. Position of contact with Sabará Formation } \\
\text { estimated. }\end{array}$ & 0 & 6.5 & 6.5 \\
\hline Phyllite, gray, carbonaceous, poorly exposed............ & 6.5 & 8.3 & 1.8 \\
\hline 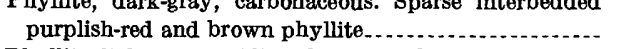 & 8.3 & 13.7 & 5.4 \\
\hline $\begin{array}{l}\text { Phyllite, light-gray and light-brown, carbonaceous, poorly } \\
\text { exposed }\end{array}$ & 13.7 & 20.2 & 6.5 \\
\hline $\begin{array}{l}\text { Phyllite, light-brown. Trace light-gray carbonaceous } \\
\text { schist. }\end{array}$ & 20.2 & 22.1 & 1. 9 \\
\hline $\begin{array}{l}\text { Phyllite, light- to dark-purplish-red. Some interbedded } \\
\text { light- to dark-gray carbonaceous phyllite. Contact } \\
\text { with underlying Taboñes Quartzite................. }\end{array}$ & 22.1 & 28.8 & 6.7 \\
\hline
\end{tabular}

SABARÃ FORMATION

The Sabará Formation, the uppermost formation of the Minas Series, is poorly exposed and is weathered to brown and red saprolite. Consequently, little is known of its lithology, structure, or thickness. At its type locality 40 kilometers northeast of the mapped area, Gair (1958) reported the presence of phyllite, schist, graywacke, tuff, chert, and iron-formation. Between the type locality and the western Serra do Curral, Pomerene (1964, p. 27) stated that the formation is thoroughly weathered, and the few relatively fresh exposures are subgraywacke, graywacke, and chloritic quartzite. Weathered outcrops indicate that most of the Sabará Formation is phyllite and schist in the western Serra do Curral. The only other recognized lithologies are conglomerate at three places and graywacke or volcanic agglomerate at one.

One conglomerate is exposed along the Belo Horizonte-Sã. Paulo highway (pl. 2, N. 10,000 E. 5,700 ) where a 70 -meter-thick bed was uncovered in a roadcut. The bed contains well-rounded pebbles and cobbles of quartzite, phyllite, and weathered granite embedded in a phyllitic matrix.

A second conglomerate exposure, possibly the same bed that is exposed along the highway, is about 1 kilometer to the northeast (pl. 2, N. 10,600 E. 6,400); it is one of the two outcrops of fresh rock found in the formation. Gneiss, quartzite, and phyllite pebbles and cobbles occur in a dense dark-green, siliceous matrix. Thin sections were cut from two of the gneiss pebbles. The gneiss contains large sericitized plagioclase laths, perthitic orthoclase and microcline, quartz, granular aggregates of chlorite and epidote(?), and many small grains of black opaque minerals and is cut by carbonate veinlets. The source of the pebbles was not determined.

The third conglomerate (pl. 1, N. 13,900, E. 12,700) is a basal conglomerate overlying the Barreiro Formation. The conglomerate is about $10 \mathrm{~cm}$ thick and contains thin slabs as much as $5 \mathrm{~cm}$ long of carbonaceous phyllite in a matrix of reddish-brown phyllite.

Unweathered graywacke or volcanic agglomerate crops out along the Belo Horizonte-São Paulo highway in a roadcut (pl. 2, N. 9,200, E. 5,300). In thin section the rock was seen to contain fragments of diorite(?), biotite-garnet schist, quartzite, large plagioclase $\left(A b_{95}\right)$ phenocrysts, carbonate, and fine-grained quartz.

In the Fêcho do Funil and eastern part of the Igarapé quadrangles the Sabará Formation overlies the Barreiro Formation, but farther west it overlies the Taboões Quartzite. The base of the Sabará Formation is exposed at two places, one in contact with each underlying formation. At the west exposure the basal Sabará Formation, composed of the graywacke or volcanic agglomerate previously described, is in sharp contact with tan dense quartzite of the Taboones Quartzite. At the east exposure the basal Sabará Formation, composed of the conglomerate also previously described, lies with apparent structural conformity on carbonaceous phyllite of the Barreiro Formation.

The lack of exposure of the base of the Sabara Formation has resulted in different interpretations by at least three geologists mapping in the Serra do Curral. Gair (1958, p. 69) proposed that the Sabara Formation may be conformable with the underlying Cercadinho Formation in the eastern part of the range and may overlap younger formations of the Piracicaba Group elsewhere. Gair stated, "In the type locality, the Sabará Formation rests with apparent conformity on the Cercadinho Formation. Elsewhere it may rest with overlap on other of the formations of the Piracicaba Group."

Pomerene (1958b) described a gradational contact between the Sabará and Barreiro Formations in the central part of the range as follows:

The contact of the Barreiro Formation with the overlying Sabará Formation is less easily placed. The top of the formation is nearly always marked by a peculiar lavender-colored, conglomeratic or gritty phyllite, but this material also occurs interbedded in the upper part of the graphitic phyllite. The top of the formation is arbitrarily defined as the contact between the uppermost graphitic phyllite bed (of more than one or two centimeters in thickness) and the conglomeratic phyllite of the overlying Sabará Formation.

The author believes that the base of the Sabará Formation is a disconformity throughout the Serra do Curral and that this interpretation adequately explains the overlapping relation of the Sabara Formation with other formations in the Piracicaba Group. The thinning out of the Barreiro Formation can be explained by a 
pre-Sabara erosion surface transecting the older formations at an angle of less than $1^{\circ}$. Carbonaceous phyllite, which occurs within and near the base of the Sabará Formation, may be either indigenous to the formation or derived from the Barreiro Formation and does not preclude the presence of a disconformity.

Despite the poor exposures and limited observation of bedding attitudes, the Sabará Formation is estimated to be 400 meters thick, or about one-twelfth of its maximum outcrop width in the mapped area. Its attitudes, particularly in the Fêcho do Funil quadrangle, vary from place to place. In this respect the structure resembles the axial areas of synclines in the Quadrilátero Ferrifero where widths of outcrop bands and stratigraphic thicknesses are known to differ by large amounts. It should be noted that the interpretation offered here requires substantial thinning of the Sabará Formation from the central to the western part of the Serra do Curral.

Gair (1962, p. 40) and Pomerene (1964, p. 27) believed the Sabará Formation to be between 3,000 and 3,500 meters thick in the central part of the Serra do Curral. Subsequent work at the type locality by Teixeira da Costa (published at an earlier date, 1961) indicates that the formation occupies the trough of a faulted and complexly folded syncline and is much thinner than Gair and Pomerene believed. Therefore, the difference in thickness of the Sabara Formation at the type locality and Brumadinho area may not be as great as the thicknesses reported by Gair and Pomerene.

The northern part of the Sabará Formation band contains numerous small garnets in the western Serra do Curral and is cut by numerous quartz veins. These features are found only close to gneiss and suggest that the northern part of the band is only a thin rind above gneiss.

\section{CENOZOIC DEPOSITS}

Cenozoic deposits in the western Serra do Curral consist of alluvium and valley fill, colluvium, canga, and laterite. Canga, laterite where associated with canga, and colluvial or rolado deposits of itabirite and hard hematite are shown on plates 1,2 , and 3 and on the maps of individual iron deposits. Alluvium and valley fill were mapped locally in mine areas but, with the exception of one small alluvial deposit of compact hematite pebbles, were not studied in detail. The geologic aspects of canga are discussed in the following paragraphs; the economic aspects of canga and other Cenozoic deposits are discussed under the section on iron deposits.

Canga is a surficial iron-rich rock that has long attracted attention because of its topographic prominence and limited use as an iron ore. Canga is com- posed of colluvial or residual itabirite or compact hematite cemented by limonite. The colluvial fragments, which may include a minor proportion of constituents other than itabirite and hematite, range from silt to boulder size. The amount of limonite cement, which may contain admixed aluminum hydroxide, ranges from the minimum necessary to form a coherent mass to a high but undetermined percentage of the rock. The canga is light yellowish brown to dark brownish black. Although usually porous, canga is relatively impermeable and resistant to erosion. Where canga layers are breached and the underlying material erodes rapidly, steep-sided valleys form below the ledges or rims of canga. In other areas canga has remained in place while underlying rock was dissolved to form caves (Simmons, 1963).

Canga covers 22 square kilometers in the western Serra do Curral, 15 in the Brumadinho area, and 7 in the West End area. It caps many ridges underlain by itabirite beds and rests on slopes extending away from these ridges; it also occurs on some valley bottoms. Canga occurs directly on itabirite beds and on and in unconsolidated sediments, and, less commonly, directly overlies other rocks. Most canga in the western Serra do Curral is in large sheets on the southern slope of the serra and near the range crest. The sheets are erosional remnants of a once much larger sheet which nearly covered the entire south side of the serra. This blanket was 1-3 meters thick at most places and much thicker at some places.

Although most canga is formed in itabirite colluvium, one canga variety is derived from the weathering of itabirite in place. Canga developed in this manner passes through three overlapping stages of weathering. In the first, quartz is dissolved to form soft itabirite. In the second, hematite is hydrated to limonite and the rock is enriched in iron by the precipitation of limonite from meteoric waters. In the third, hydration of hematite and addition of limonite is sufficient to form a hard canga layer. Where bedding is recognizable in this canga it is known as structure canga. The gradation of structure canga downward into enriched itabirite and soft itabirite is exposed in the upper workings of the Candú mine.

Another variety of canga is canga rica; it is composed chiefly of compact hematite fragments and may contain as much as 68 percent iron.

\section{IGNEOUS ROCKS \\ GRANITIC ROCKS}

The granitic rocks of the Quadrilátero Ferrifero are classified according to petrology and age; five principal petrologic types are recognized. As a result of potassium-argon age determinations of micas, Herz 
and others divided the granitic rocks into four age groups, one with two divisions (Herz and Dutra, 1958; Herz, in Departamento Nacional da Produção Mineral, 1959, p. 85-93; Herz and others, 1961, p. 1111-1118). Each of the petrologic types corresponds to one of the age divisions. In order of decreasing age, these are: Group I, Engenheiro Corrêa Granodiorite; Group II, Itabirito Granite; Group IV or "mixed rocks," Cachoeira do Campo Granite; Group III gneissic facies, granite at Itabira; Group III granitic facies, Borrachudos Granite.

The above named granitic rocks are considered the typical rocks for each age group. Herz designated many unnamed granitic rocks by the group to which they belong or as a type of one of the granitic rocks; for example, an unnamed Group II rock may be referred to as an "Itabirito-type" rock. In more recent papers other granitic rocks within Herz's groups have been named. One such rock in the western Serra do Curral is in this category, the Souza Noschese Gneiss, a Group III gneissic facies rock.

Subsequent to the completion of mapping in the Quadrilátero Ferrifero, other age studies of granitic rocks were made by L. T. Aldrich (unpub. data). These studies include rubidium-strontium and potassiumargon age determinations of feldspars and micas. They have shown that the history of granitic rocks in the Quadrilatero Ferrifero is more complicated than previously envisioned. The new data permit four alterations to the conclusions reached by Herz: First, Some of the Group IV rocks may represent a separate period of widespread intrusion; Group IV rocks had been considered as hybrids between Group II and Group III gneissic facies because of their intermediate chemical and mineralogic compositions, textures, and ages. Second, All of the groups and divisions, with the exception of the Group III gneissic facies which is dated 500 million years, are older than was indicated by the first age determinations. Third, The relative age position of the Group III granitic facies is between Group II and Group IV rather than youngest of the granitic rocks.
Fourth, The absolute ages of the granitic rocks, Group III gneissic facies excluded, are uncertain within wide limits.

With the exception of the Group III granitic facies, the granitic rocks of the Quadrilátero Ferrifero occur as integral parts of gneiss dome structures. In ideally developed gneiss domes, cores of older granitic rocks are completely enveloped by zones, as much as several kilometers wide, of successively younger granitic rocks. This occurs in such a manner that only the outermost zone of youngest granitic rock is in contact with stratified rocks. The western Serra do Curral area contains parts of two gneiss domes, one north and one south of the range. That part of the north gneiss dome within the mapped area includes granitic rocks belonging to Group IV and Group III gneissic facies; Group II rocks are present in an older part of the dome northeast of the area. Granitic rocks of Group II and Group III gneissic facies are in the south or Bonfim dome within the mapped area; Group IV rocks are present in part of the dome south of the area. The granitic rocks of the western Serra do Curral are compared with the age groups, type granitic rocks, and ages of granitic rocks of the Quadrilá tero Ferrífero in table 5.

\section{ITABIRITO(?) GNEISS}

Gneiss which is very similar to Itabirito Granite underlies 18 square kilometers in the southeast corner of the Brumadinho area (pl. 1). It is part of a much larger body of Itabirito(?) Gneiss that occupies most of the western third of the Piedade do Paraopeba quadrangle to the east. The gneiss extends south from that quadrangle and the Brumadinho area for more han 20 kilometers. Within the Brumadinho area the gneiss is well exposed near the community of Alberto Flôres in a small quarry (pl. 1, N. 2,900, E. 9,600), railroad cuts, and in abutments for the Estrada de Ferro Central do Brasil bridge over the Rio Paraopeba.

The rock is a gray medium- to coarse-grained, wellfoliated granodiorite gneiss with alternating biotiterich and felsic layers. The gneiss contains microcline

TABLE 5.-Correlation of the granitic rocks of the western Serra do Curral with age groups, type granitic rocks, and granitic rock ages in the Quadrilatero Ferrifero

[Age in millions of years]

\begin{tabular}{|c|c|c|c|c|}
\hline \multicolumn{2}{|c|}{ Quadrilátero Ferrffero granitic rocks } & \multirow{2}{*}{$\underset{\text { age I }}{\text { Estimated }}$} & \multicolumn{2}{|c|}{ Western Serra do Curral granitic rocks } \\
\hline Age groups & Type rock & & Bonfim dome & North dome \\
\hline Group III gneissic facies. ....... & Granite at Itabira & 500 & Souza Noschese Gneiss..... & Souza Noschese(?) Gneiss. \\
\hline Group IV or "mixed" rocks. & Cachoeira do Campo Granite & 1,000 & - & Gneiss. \\
\hline Group III granitic facies & Borrachudos Granite & 1,350 & - & \\
\hline Group II. & Itabirito Granite & $1,350-2,600$ & Itabirito(?) Gneiss.......... & \\
\hline Group I. & Engenheiro Corrøa Granodiorite & $>2,600$ & - & \\
\hline
\end{tabular}

I Based on potassium-argon age determinations of biotite (Herz and others, 1961, p. 1111-1120) and rubidium-strontium age determinations of feldspars (L. T. Aldrich, unpub. data). 
augen as long as $2 \mathrm{~cm}$ in a groundmass of smaller microcline, plagioclase, quartz, and biotite grains. The plagioclase is partly intergrown with microcline in the form of myrmekite, and the biotite is rutilated. Apatite, zircon, sphene, epidote, and muscovite are common accessory minerals. The percentages of normative minerals were computed from chemical analyses of these rocks. These analyses can be compared with modal analyses of the same rocks in table 6 .

TABLE 6.-Analyses of granitic rocks from the Brumadinho area
compared with average analyses of Group II and Group III granitic rocks of the Quadrilatero Ferrifero

[n.d., not detected; P, present]

\begin{tabular}{|c|c|c|c|c|c|}
\hline \multicolumn{2}{|c|}{ Itabirito(?) Gneiss } & \multirow{2}{*}{$\begin{array}{c}\text { Group } \\
\text { II i } \\
\text { average }\end{array}$} & \multicolumn{2}{|c|}{$\begin{array}{c}\text { Souza Noschese } \\
\text { Gneiss }\end{array}$} & \multirow{2}{*}{$\begin{array}{c}\text { Group } \\
\text { III ? } \\
\text { average }\end{array}$} \\
\hline 1 & 2 & & 3 & 4 & \\
\hline
\end{tabular}

Chemical analyses

[Analyzed by P. L. D. Elmore, I. H. Barlow, S. D. Botts, and G. Chloe, Washington, D.C. in percent]

\begin{tabular}{|c|c|c|c|c|c|c|}
\hline $\mathrm{SiO}_{2} \ldots \ldots \ldots$ & 71.4 & 73.1 & 67.8 & 75.7 & 74.0 & 74.2 \\
\hline $\mathrm{Al}_{2} \mathrm{O}_{3} \ldots$ & 14.6 & 13.8 & 14.6 & 13.6 & 14.1 & 13.6 \\
\hline $\mathrm{Fe}_{2} \mathrm{O}_{3} \ldots$ & 1.0 & .6 & 1.1 & .5 & .4 & .7 \\
\hline FeO & 1.7 & 1.9 & 2.6 & .70 & .65 & 1.1 \\
\hline MgO ................. & .72 & .63 & 1.5 & .30 & .20 & .43 \\
\hline $\mathrm{CaO}$ & 2.0 & 1.9 & 2.6 & .47 & .89 & .83 \\
\hline $\mathrm{Na} a_{2} \mathrm{O} \ldots \ldots$ & 4.8 & 3. 3 & 3.8 & 3.0 & 3.6 & 3.2 \\
\hline $\mathbf{K}, 0 \ldots$ & 2.1 & 3.4 & 3. 8 & 4.7 & 4.9 & 4.8 \\
\hline $\mathrm{H}_{2} \mathrm{O} \ldots$ & .60 & .63 & .72 & .58 & .38 & .66 \\
\hline $\mathrm{TiO}_{2}$ & .43 & .30 & .57 & .08 & .12 & .25 \\
\hline $\mathrm{P}_{2} \mathrm{O}_{5} \ldots$ & .12 & .10 & .25 & .03 & .02 & .07 \\
\hline MnO & .08 & .06 & .09 & .06 & .04 & .05 \\
\hline $\mathrm{CO}_{2}$ & .06 & .05 & .09 & .05 & .36 & .17 \\
\hline F. & n.d. & n.d. & .07 & n.d. & n.d. & .04 \\
\hline Sum................ & 99.6 & 99.8 & 99.6 & 99.6 & 99.7 & 100.2 \\
\hline
\end{tabular}

\section{Minor-element analysea}

[Analyzed by C. V. Dutra, Instituto do Tecnologia Industrial, Belo Horizonte, M. G., Brazil. In parts per million]

\begin{tabular}{|c|c|c|c|c|c|c|}
\hline Ba.. & 1,300 & 800 & 1,250 & 390 & 1,300 & 710 \\
\hline Be............... & 4.3 & 5.4 & 3.3 & 5.8 & n.d & 4.0 \\
\hline Co................... & 5.3 & 4. 0 & 8.2 & 1.3 & 1.3 & 2.0 \\
\hline $\mathrm{Cr}_{-}$ & 18 & 5.6 & 25 & .7 & .8 & 1.6 \\
\hline $\mathrm{Cu} \ldots$ & 3.2 & 12 & 13 & .6 & 14 & 1.2 \\
\hline Ga_............... & 14 & 16 & 17 & 13 & 15 & 15 \\
\hline La... & 150 & 94 & 98 & 14 & 27 & 63 \\
\hline Mo ................. & 4.0 & n.d. & 1.8 & n.d. & n.d. & 3.7 \\
\hline $\mathrm{Nb}$ & 20 & 32 & 26 & 22 & 13 & 19 \\
\hline Ni............ & 7.5 & 4.8 & 18 & .8 & .8 & 3.5 \\
\hline $\mathrm{Pb}$ & 27 & 32 & 28 & 36 & 53 & 16 \\
\hline Se & 8.1 & 6.5 & 8.8 & 1.0 & 1.3 & 4.3 \\
\hline - & 9.0 & n.d. & 36 & 12 & n.d. & 25 \\
\hline Sr & 250 & 150 & 280 & 56 & 220 & 98 \\
\hline$V_{1}$ & 55 & 24 & 41 & 8.1 & 11 & 10 \\
\hline $\mathbf{Y}$ & 42 & 57 & 59 & 83 & 6.3 & 87 \\
\hline Zr & 470 & 400 & 270 & 64 & 93 & 190 \\
\hline
\end{tabular}

TABLE 6.-Analyses of granitic rocks from the Brumadinho area compared with average analyses of Group II and Group III granitic rocks of the Quadrilátero Ferrifero-Continued

\begin{tabular}{|c|c|c|c|}
\hline Itabirito(?) & Gneiss & $\underset{\text { II } 1}{\text { Group }}$ & $\begin{array}{c}\text { Souza Noschese } \\
\text { Gneiss }\end{array}$ \\
\hline 1 & 2 & & 3 \\
\hline
\end{tabular}

Normative minerals

[Catanorms calculated from cation percentages by $\mathrm{N}$ orman Herz]

\begin{tabular}{|c|c|c|c|c|c|c|}
\hline Quartz & 27.8 & 33.1 & ......... & 36.4 & 30.0 & \\
\hline Orthoclase. & 12.6 & 20.6 & ......... & 28.4 & 29.4 & \\
\hline Plagioclase & 53. 0 & 39.4 & ......... & 29.9 & 37.3 & \\
\hline & $\left(\mathrm{Ab}_{83}\right)$ & $(\mathrm{Ab} \eta 7)$ & $\ldots \ldots$ & (Ab92) & (Ab88) & \\
\hline Albite & 43.7 & 30.3 & ......... & 27.6 & 32.9 & \\
\hline Anorthite......... & 9.3 & 9.1 & ........ & 2.3 & 4.4 & \\
\hline Corundum ......... & 1.2 & 1.6 & & 3.1 & 1.5 & \\
\hline Enstatite & 2.0 & 1.8 & & .8 & .6 & \\
\hline Ferrosilite & 1.5 & 2.2 & $\ldots$ & .7 & .6 & \\
\hline Magnetite . . . . & 1.1 & .7 & ........ & .5 & .4 & \\
\hline Dmenite..... & .6 & .4 & - n...... & .1 & .2 & \\
\hline Apatite. & .2 & .2 & ......... & .1 & .0 & \\
\hline
\end{tabular}

Modal analyses

[By Norman Herz. In percent]

\begin{tabular}{|c|c|c|c|c|c|c|}
\hline Quartz & 31 & 32 & 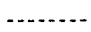 & 37 & $\cdots$ & $\cdots$ \\
\hline Potassium feldspar.... & 29 & 10 & - n..... & 20 & $-\ldots \ldots$ & ........ \\
\hline Plagioclase ... & 33 & 35 & (n....... & 31 & $\cdots$ & \\
\hline & $\left(A b_{B 5}\right)$ & (Ab85) & ... & $\left(A b_{86}\right)$ & & \\
\hline Biotite & $\mathbf{5}$ & 8 & $\cdots$ & 2.5 & $\cdots$ & \\
\hline Muscovite & 1 & 9 & ........... & 5 & $\cdots$ & \\
\hline Epidote & 1 & 7 & $\ldots$ & 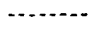 & $\cdots$ & \\
\hline Chlorite... & $\mathbf{P}$ & $\mathbf{P}$ & -........ & 4 & -........ & \\
\hline Apatite & $\mathbf{P}$ & $\mathbf{P}$ & -.. & …. & -..- & \\
\hline Zircon. & $\cdots$ & $\mathbf{P}$ & $\cdots$ & $\mathbf{P}$ & ..... & $\cdots$ \\
\hline Garnet.................. & $\ldots+\ldots$ & 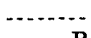 & (.......... & 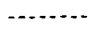 & $\cdots$ & $\cdots$ \\
\hline Rutile & ........ & $\mathbf{P}$ & (.......... & (n........ & & \\
\hline Opaque & -......... & $\mathbf{P}$ & $\cdots+\cdots$ & (n).......... & & \\
\hline Carbonate & -...-. & -...-..- & - n...... & .5 & ...... & \\
\hline
\end{tabular}

1 Data for Group II average and Group III average published by Herz and Dutra $(1960$, p. 86-87).

\section{SAMPLE LOCALITY}

Sample 1. Small quarry on west side of Brumadinho-Bonfim road, 1,850 meters north of Brumadinho area south boundary (pl. 1).

2. Small quarry on east side of road and 200 meters south of confluence of Córrego Riacha Piedade with the Rio Paraopeba (pl. 1).

3. Small quarry on north side of Souza Noschese, 100 meters west of the railroad (pl. 1).

4. Same locality as sample 1 .

Although no age determinations have been made from the gneiss in the southeastern part of the Brumadinho area, the gneiss is tentatively correlated with the Itabirito Granite at its type locality (Herz, in Departamento Nacional da Produção Mineral, 1959, p. 88) and with the Group II gneiss at the Pardo Lopes quarry in Belo Horizonte (Pomerene, 1964, p. 32). The correlation is based on similarity in physical appearance, foliation, mineral content, and geologic position. Nevertheless, it should be pointed out that the chemical composition and trace-element suite (table 6) are slightly atypical of Group II rocks. These 
differences probably result from the effects of younger granitic rock emplacement. The analyzed samples were taken from the freshest exposures available, but these exposures are at localities near younger Group III rocks. Indeed, the variations in composition from the average of Group II analyses are in the direction of the composition of Group III rocks.

In the Brumadinho area the Itabirito(?) Gneiss is in contact with only the Souza Noschese Gneiss; this contact has a linear extent of 10 kilometers. The only exposure showing a relationship between the two gneisses is in a very small quarry on the west side of the Brumadinho-Bonfim road (pl. 1, N. 1,900, E. 6,700). The Itabirito(?) Gneiss is cross cut by Souza Noschese Gneiss, and both rocks are cut by pegmatite (fig. 7).

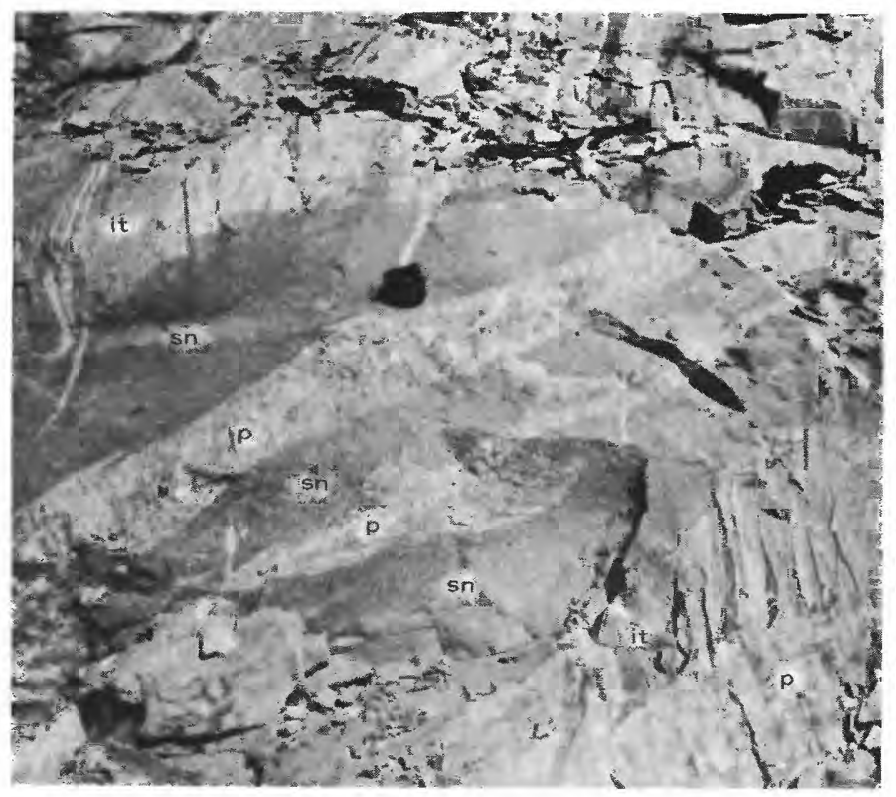

Frgure 7.-Itabirito(?) Gneiss (it) intruded by Souza Noschese Gneiss (sn); both gneisses intruded by pegmatite $(p)$.

The well-developed foliation in the Itabirito(?) Gneiss, the poorly developed foliation in the Souza Noschese Gneiss, and the faint foliation in the pegmatite are all parallel. The relations clearly establish the relative rock ages, from oldest to youngest, Itabirito(?) Gneiss, Souza Noschese Gneiss, pegmatite. The parallel foliation in the three rocks suggests a minor degree of recrystallization after emplacement of the pegmatite.

\section{GROUP IV GNEISS IN THE ITAÚNA UPLANDS}

Granodiorite gneiss, which probably belongs in Group IV, underlies 45 square kilometers in the Itaúna uplands in the northwestern corner of the West End area (pl. 3). This rock was not mapped in detail, and it is possible that some Group III rocks possibly occur within the area of Group IV rocks shown on plate 3 as 'ign. The contact between the rocks of Groups III and IV is based in part on interpretation of aerial photographs; Group IV rocks generally underlie terrain characterized by more rugged topography.

The Group IV granodiorite gneiss is light gray and is commonly medium grained but has coarse-grained facies. The rock is moderately to poorly foliated and does not have the distinct alternating biotite-rich and felsic bands characteristic of Itabirito(?) Gneiss. It is composed of quartz, sodic plagioclase, microcline, biotite, and accessory sericite, epidote, and zircon. The microcline contains many minute sericite(?) and quartz(?) inclusions and replaces quartz and other feldspars.

Two north-striking quartzite beds were found in traverses on the gneiss, but their linear extent as shown on the geologic map was interpreted mostly from aerial photographs. The quartzites vary from milky white to grayish pink and from a dense rock resembling novaculite to a variety containing elongated quartz grains, which are as much as $2 \mathrm{~cm}$ long but only $2 \mathrm{~mm}$ thick, in a mass of crushed, very fine grained quartz. The original quartz grains and bedding were destroyed by crushing and recrystallization. Similar beds 7 kilometers northwest of the mapped area show traces of normal bedding and of crossbedding; some are isolated in gneiss, but others are interbedded with dolomite and iron-formation.

The parallelism of the quartzite beds with the general strike of the Nova Lima Group rocks south of the Serra do Curral suggests the possibility that the beds are part of the Nova Lima Group. The occurrence of similar quartzite beds with what are considered to be Nova Lima Group rocks north of the mapped area also suggests this possibility.

\section{SOUZA NOSCHESE GNEISS}

The name Souza Noschese Gneiss is here given to the granite gneiss in the central part of the Brumadinho area. The gneiss is well exposed in several small quarries near the community Souza Noschese on the Rio Paraopeba.

The Souza Noschese Gneiss is a Group III gneissic facies rock. A potassium-argon age determination of biotite from a sample of Souza Noschese Gneiss indicated an age of 493 million years (Herz and others, 1961 , p. 1112 , table 1 , sample 33 ). The sample came from a dike in Itabirito(?) Gneiss near the BrumadinhoBonfim road (pl. 1, N. 1,900, E. 6,700). This is the youngest age yet obtained for Group III gneissic facies rocks in the Quadrilátero Ferrífero.

The Souza Noschese Gneiss underlies 90 square kilometers in the Brumadinho area and crops out within a band 6 kilometers wide and 15 kilometers 
long (pl. 1). The gneiss extends for 10 kilometers east of the Brumadinho area (Pomerene, 1964, p. 32) and thence south for at least 35 kilometers (Wallace, 1965). To the west, Souza Noschese Gneiss is present in the southeast corner and about 2 kilometers south of the West End area (pl. 2).

This rock is a light-gray fine- to medium-grained poorly foliated granite gneiss. It contains quartz, potassium feldspars, plagioclase, muscovite, biotite, and chlorite; zircon is a common accessory mineral. Most larger quartz grains are strained, and some quartz forms perthitic intergrowths with plagioclase. The potassium feldspar grains are as long as $5 \mathrm{~mm}$ and commonly contain many minute sericite(?) and quartz(?) inclusions. The chlorite occurs as rims around biotite. The mineral composition of the Souza Noschese Gneiss is uniform within narrow limits except near its contact with the Moeda Formation. Within the 1- to 2-meter-thick zone adjacent to the Moeda Formation the quartz content is much higher, and other minerals are proportionately less abundant. The quartz content of the Souza Noschese Gneiss is generally about 35 percent; however, the quartz content is as much as twice this amount in this zone and is highest at the contact with the Moeda Formation. The percentages of normative minerals were computed from chemical analyses of Souza Noschese Gneiss. These analyses can be compared with a modal analysis of one of the same samples (table 6). The chemical analyses of Souza Nosches Gneiss have been compared with the analyses of Group III gneissic facies rocks of the Quadrilátero Ferrífero (Herz and Dutra, 1960, p. 87), and the two were found to be conformable in all constituents.

Comparison of minor-element analyses of the same samples (table 6) with the ranges for Group III gneissic rocks presented by Herz and Dutra (1960, p. 86) show some divergences. Both samples of Souza Noschese Gneiss are lower in chromium, nickel, scandium, and zirconium and higher in lead, and in addition the sample from the Brumadinho-Bonfim road is lower in tin and yttrium and higher in barium, copper, and strontium than the ranges published by Herz and Dutra. These variations of the Souza Noschese sample are minor, and in general the gneiss resembles other Group III gneissic rocks.

The mineralogy, texture, chemical composition, trace-element suite, geologic position, and age determination show the Souza Noschese Gneiss to be similar to many other Group III gneissic facies rocks in the Quadrilátero Ferrífero, and tentative correlation is made with all the granitic rocks having the same characteristics in the western part of the Quadrilatero Ferrifero.

\section{GROUP III GNEISS IN THE IGARAPÉ PEDIMENTS}

A Group III granodiorite gneiss underlies 110 square kilometers in the Igarapé pediments. It is in contact with the Minas Series on the south (pls. 2,3) and with a Group IV gneiss to the northwest (pl. 3). The Group III gneiss is poorly exposed throughout most of the pediments as it is deeply weathered and covered by Quaternary sediments. The only hard-rock exposures found are within 4 kilometers of the west boundary of the area.

The gneiss is a poorly foliated gray to tan mediumto fine-grained granodiorite. It is composed of microcline, quartz, plagioclase, biotite, chlorite, sericite, and tourmaline(?). Both microcline and quartz are intergrown with plagioclase. Pleochroic halos in the chlorite show that it was derived from biotite.

The gneiss in the Igarapé pediments has not been studied or mapped in enough detail to determine whether it is the same granitic rock as the Souza Noschese Gneiss. Mapping south of the West End area and around the southwest end of the Serra do Curral will be necessary before this can be determined. The mineral composition and geologic position of the two rocks are similar, and, if not part of the same granitic body, they may be correlative.

\section{DIKE ROCKS}

Metadiabase dikes, plugs, and sills occur throughout the western Serra do Curral and intrude all Precambrian rocks. The largest plug covers about 0.5 square kilometer near the center of the Igarape quadrangle (pl. 2). At the few fresh exposures in roadcuts the rocks are very dark green. At other places the feldspars weather to a mottled white. Further weathering results in the development of brown and brownish-red soils.

The metadiabase consists of twinned plagioclase laths surrounded by smaller crystals of plagioclase, pigeonite, and accessory ilmenite and biotite. Some plagioclase was replaced by sericite, chlorite, quartz, and epidote. The rims of many pigeonite crystals are altered to uralite. Other pigeonite is partly and completely replaced by chlorite, biotite, and magnetite. Most ilmenite is partly altered to leucoxene, and some biotite has altered to chlorite.

Weathered porphyritic dikes occur at the head of the old tram line leading from the Candù mine area to Fêcho do Funil (pls. 1, 5) and along the contact of the Moeda and Batatal Formations, about 200 meters east of the Belo Horizonte-São Paulo highway (pl. 2). Although deeply weathered, the dikes are distinctive; large feldspar phenocrysts have weathered to form white clay "eyes" in a reddish-brown clay mass. The only fresh rock known in the Serra do Curral 
that might weather in this manner is a metamorphosed diabase porphyry at Fazenda Rosário in the Ibirité quadrangle, east of the Brumadinho area (Pomerene, 1964, p. 35).

\section{STRUCTURE}

Parts of four major structural features occur in the western Serra do Curral region: the Bonfim gneiss dome; a gneiss dome on the north side of the range here called the northern gneiss dome; the south limb of a Minas Series syncline (Piedade syncline) forming the crest and north flank of the range; and a group of north-trending folds in rocks of the Nova Lima Group. A fifth feature, a thrust fault postulated to have lain on the north flank of the Serra do Curral, may have effected the present rock distribution (fig. 4).

\section{BONFIM GNEISS DOME}

The Bonfim gneiss dome is a very large structure bounded on the north by the Serra do Curral and on the east by the Serra da Moeda, where gneiss is in contact with folded rocks of the Nova Lima Group, and by the base of the Minas Series where the Nova Lima Group is absent. Only the northern part of the dome lies within the mapped area, but the gneiss is known to extend south for at least 50 kilometers.

Within the mapped area the outer ring of the Bonfim dome is made up of Souza Noschese Gneiss, which crops out in a band averaging 6 kilometers wide. South of this the Itabirito(?) Gneiss is known to crop out at various places over a distance of 50 kilometers between the towns of Moeda and Itaguara. It should be noted that the younger gneiss envelops the older and that, in this respect, the structure resembles the Bação gneiss dome (Herz and others, 1961, p. 1113); the Bação dome is 8 kilometers east of the Bonfim dome and is 35 kilometers southeast of the Brumadinho area (fig. 3). Three granitic groups are found in the Bação dome: a core of Engenheiro Corrêa Granodiorite (Group I), an intermediate ring of Itabirito Granite (Group II), and an outer rim of Group III granodiorite gneiss. If the two domes are fully analogous, it can be expected that Group I granitic rock will be found in the central part of the Bonfim dome.

Foliation in the Bonfim dome strikes north and dips steeply except near the margin, where the foliation parallels the contact with metasedimentary rocks. Foliation parallel to the dome fringe is limited to the outer 1 kilometer of the dome and therefore occurs only in the Souza Noschese Gneiss. Although the foliation of the Itabirito(?) Gneiss is well developed and that of the Souza Noschese Gneiss is weakly developed, the structural attitude in both rocks is approximately concordant. About 80 percent of the foliation symbols on the Itabirito(?) Gneiss on plate 1 show strikes within $10^{\circ}$ of north; about 65 percent of the dips are more than $60^{\circ}$. Strike of the Souza Noschese Gneiss foliations is slightly more variable, and most dips are $75^{\circ}$ or steeper. As previously described under Itabirito-type gneiss, the foliation of the two gneisses is continuous and parallel at their only known contact exposures (fig. 7). Foliation of the two rocks is approximately parallel along the Rio Paraopeba, where both gneisses are exposed in railroad cuts near their contact (pl. 1).

\section{GNEISS DOME NORTH OF THE SERRA DO CURRAL}

The gneiss dome north of the Serra do Curral extends the length of the range, or more than 100 kilometers, and extends, unconformably overlain by Paleozoic(?) limestones, for an undetermined distance north of the Quadrilátero Ferrífero.

The structure of the north gneiss dome differs from that of the Bonfim dome in several respects. First, the outer shell of younger rock (Group III) is relatively thin, as little as 2 kilometers wide in the Serra Azul quadrangle. Second, its inner part in the western Serra do Curral area is Group IV gneiss instead of Group II gneiss as in the Bonfim dome. The southern fringe of the north dome was studied to the east and northeast of the Brumadinho area by Norman Herz and the author in 1960. That study indicates that the rim of Group III gneissic rock thins to a width of several hundred meters and may be locally absent. It also indicates that Group IV gneiss lies between the outer shell of Group III rock and Group II rock toward the center of the dome in the Belo Horizonte quadrangle. Third, in contrast to the north flank of the Bonfim dome, where the oldest unit of the Minas Series (or the Nova Lima Group) is in contact with Souza Noschese Gneiss (pl. 1), the youngest units of the Minas Series are either intruded by or in fault contact with the outer gneiss of the north dome (pls. 2, 3).

\section{FOLDS IN THE NOVA IIMA GROUP}

North-trending folds occur in the Nova Lima Group on the north side of the Bonfim dome and south of the Piedade syncline limb (pl. 2). In the Serra das Queias, iron-formations and ferruginous phyllite beds crop out as continuous and resistant ledges and ridges, some of which can be traced for several kilometers. Although steeply dipping beds were found in a few places, the iron-formations are characterized by north strikes and gentle to moderate dips to east and west. Unfortunately, time did not permit the detailed mapping of all these units; only those beds which were traced in the field are shown on plate 2. Others seen from a distance and on aerial photographs have the same type of outcrop 
pattern as those mapped. North-trending folds may be present in the Nova Lima Group away from the Serra das Queias. However, the determination of structure outside of that area was hindered by the lack of resistant beds and by the resultant poor exposures, and the similarity in structure was not definitely established.

As previously discussed, the Souza Noschese Gneiss is in contact with stratified older rocks of the Nova Lima Group and Minas Series on the northern side of the Bonfim dome. Structures found in these stratigraphic units differ considerably, and folds in the Nova Lima Group trend north, whereas those in the Minas Series trend $\mathrm{N} .70^{\circ} \mathrm{E}$. These basic differences in structural trends, indicative of two different periods of orogeny, are confirmed by a major angular unconformity between the Nova Lima Group and the Minas Series in the western Serra do Curral and other parts of the Quadrilátero Ferrífero (Rynearson and others, 1954).

Because only the Souza Noschese Gneiss is in contact with the older stratigraphic series on the north side of the Bonfim dome, it cannot be determined within the western Serra do Curral how the orogeny resulting in the early folding of the Nova Lima Group is related to the Itabirito(?) Gneiss and the development of the Bonfim gneiss dome. Nevertheless, the prallelism of Nova Lima bedding-plane foliation with the northstriking foliation of the Itabirito-type gneiss suggests that both rocks underwent deformation together, presumably in pre-Minas time.

Deformation of the Nova Lima Group in the western Serra do Curral appears less intense than in other parts of the Quadrilatero Ferrifero. The folds in the Serra das Queias are much gentler than the Nova Lima folds mapped elsewhere. In the eastern part of the Quadrilátero Ferrifero, mapping in the Gongo Sôco and Conceição do Rio Acima quadrangles by S. L. Moore (written commun.) and in the Catas Altas quadrangle by C. H. Maxwell (written commun.) indicates that the rocks called Nova Lima are compressed into isoclinal folds there. Even more intensely contorted Nova Lima rocks in the Nova Lima and Rio Acima quadrangles in the central part of the iron region were mapped by Gair (1962, pls. 1, 2).

\section{PIEDADI SYNCLINE}

The Piedade syncline is the longest linear structure in the Quadirlátero Ferrifero. The south limb of the syncline forms the Serra do Curral and extends from southwest of Serra Azul in the Córrego do Soldado quadrangle for more than 100 kilometers to its northeast end in the Piedade quadrangle (fig. 3). More than 40 kilometers of its length lie in the western Serra do Curral. As discussed in the following section, the north limb is missing throughout most of the length of the syncline.

In the western Serra do Curral the south limb of the Piedade syncline dips steeply northward and in many places is overturned toward the south. The greatest overturning occurs in the Serra Azul section of the range, where the limb dips from $10^{\circ}$ to $40^{\circ} \mathrm{S}$. Highangle dips, overturned and normal, predominate in the remainder of the area. The folding of the Piedade syncline was undoubtedly the result of the general compression from the southeast found throughout the Quadrilátero Ferrifero and was responsible for such features as the large overturned folds in the Monlevade district (Reeves, 1966), the Gandarela syncline (J. E. O'Rourke, S. L. Moore, and G. C. Simmons, unpub. data), and the thrust faults in the Congonhas district (Guild, 1957, p. 34-36), Dom Bosco quadrangle (Johnson, 1962, p. 27-30), and Ibirité and Macacos quadrangles (Pomerene, 1964, p. 39).

Subsidiary longitudinal folds on the south limb, some gently flexed and others isoclinally folded, parallel the strike of the Piedade syncline. Folds of this type undoubtedly occur in all formations involved in the Piedade syncline. However, the continuity and exposure of the folds are such that they were mapped in only two areas. Gently flexed folds exposed near the Candú mine (pls. 1, 5) involve the Moeda Formation, Batatal Formation, and Cauê Itabirite. Prominent isoclinal folds occur on Pico dos Tres Irmãos in the Cauê Itabirite (p. 1). Isoclinal folds in the Cauê Itabirite were found in two exploratory drifts recently driven under the canga-covered area surrounding the Córrego do Feijão iron deposit on the southeast side of Pico dos Tres Irmãos. Thus, it appears that all the Piedade syncline limb south of the Serra do Curral crest, in the vicinity of Pico dos Tres Irmãos, may be involved in a series of isoclinal folds parallel to the general strike of the Piedade syncline.

Numerous folds, known as cross-range folds, also occur in the south limb of the Piedade syncline. As their name implies, the axial planes of these folds are transverse to the strike of the Serra do Curral and, hence, also to the Piedade syncline. The folds are best exposed in the Cauê Itabirite along the range crest where the flexures, contrary to the regional strike, are are reflected in local sinuosity of the range crest. The two largest compact hematite deposits in the western Serra do Curral, Córrego do Feijão and Candú, are localized on cross-range synclines.

The chronological sequence of longitudinal and cross-range folds is uncertain, but they are probably contemporaneous. The longitudinal folds undoubtedly resulted from the same compression which folded and then overturned the Piedade syncline. It is reasonable 
to assume that the cross-range folds resulted from local differences in the pressure. Because only one post-Minas orogeny is recognized in the Quadrilátero Ferrifero, it is easier to conceive of the folds as essentially contemporaneous than to postulate another orogeny for which evidence is lacking. Longitudinal and crossrange folds occur together on Pico dos Tres Irmãos (pl. 1). Unfortunately, the axis of the cross-range fold is covered by canga on the south side of the mountain. Thus, the relation of the differing fold directions is largely indeterminable.

Small reverse faults may be present at several places in the syncline limb, but the only ones observed are in the two exploration drifts mentioned previously. The faults strike parallel to the Piedade syncline; the displacement is from the southeast and ranges from a few meters to a few tens of meters. At least one of these faults offsets compact hematite ore, indicating that compression from the southeast took place after the formation of the ore. As ore deposits are located on folds presumably developed by compression from the same direction, compression starting before the formation of ore deposits may have continued during and after their formation.

Nearly vertical normal faults, most of which show only a few meters displacement, transect the strike of the Piedade syncline limb at several places. The topographic expression of the faults-erosional notches in ridges underlain by the Cauê Itabirite, Cercadinho Formation, and Taboões Quartzite-indicates their location in the field. The faults are seldom mappable in argillaceous rocks but undoubtedly pass into and through such units. The normal faults postdate the other structures in the Piedade syncline, but it was not determined whether they are a consequence of the orogeny that formed the other structures or are a result of subsequent tension. Four normal faults had more movement than the others. One is on the west side of the Rio Paraopeba gap through the Serro do Curral (pl. 1). A second is in the pass separating the Serra do Itatiaia and Serra do Barreiro sections of the Serra do Curral (pl. 2). The other two faults occur close together in the Serra Azul section and form a small graben (pl. 3). Maximum vertical movement on the faults was about 100 meters.

\section{NORTH LIMB OF THE PIEDADE SYNCLINE}

The absence of the north limb of the Piedade syncline for most of the syncline length, including the entire western Serra do Curral is a major unsolved problem in the Quadrilatero Ferrifero. The north limb is recognized where the syncline closes at its northeast extremity in the Piedade quadrangle. Several areas of Minas Series rocks in that area are undoubtedly part of the north limb (B. P. Alves, unpubl. data). As suggested in the section on the Sabara Formation, part of that formation near the boundary of the Santa Luzia and Nova Lima quadrangles is probably on the north limb (Teixeira da Costa, 1961). Quartzite surrounded by Group III gneiss and graphite(?) in some of the surrounding gneiss were noted in the Ibirite quadrangle by Pomerene (1964, pl. 3). He considered these rocks as possible relics of the Taboões Quartzite and Batatal Formation on the north limb of the syncline (J. B. Pomerene, written commun., 1959). However, for the 100-kilometer length of the Piedade syncline, few rocks are recognized which may represent the north limb.

Two principal hypotheses accounting for the absence of the north limb evolved during discussions among geologists of the Departamento Nacional da Produção Mineral-U.S. Geological Survey group: (a) the north limb may have been largely assimilated by gneissic rocks, or (b) assimilation by gneissic rocks was preceded by thrusting along faults approximating the contact of the syncline limb with the gneiss dome north of the Serra do Curral.

A third and less likely possibility is that the north limb of the Piedade syncline was destroyed during an older orogeny when the Group II granitic rocks were emplaced in the gneiss domes. This entails a pre-Group II age for rocks of the Minas Series. There is little reason to suppose that the Minas Series is older than Group II granitic rocks; however, as no contacts between the two rock divisions are known, the possibility cannot be discounted on the basis of present knowledge.

\section{METAMORPHISM}

\section{REGIONAL METAMORPHISM}

Practically all rocks in the western Serra do Curral are characterized by low-grade regional metamorphism of post-Minas age. Herz, Hurley, Pinson, and Fairbairn (1961, p. 1111-1112, 1118) recognized two major periods of post-Nova Lima metamorphism and orogeny in the Quadrilátero Ferrífero. These writers thought that one of the periods was post-Nova Lima and pre-Minas in age and that the other was postMinas. Structural evidence cited in the previous section proves that post-Nova Lima and pre-Minas orogeny took place in the western Serra do Curral; however, petrographic evidence for accompanying metamorphism is lacking. Thin-section studies of rocks from the Nova Lima Group do not indicate retrogression from a higher level of metamorphism to the present greenschist facies. Three hypotheses can explain the metamorphic sequence in the western Serra do Curral; in order of the author's preference, these are: (1) The metamorphic grade reached during post-Nova Lima and pre-Minas metamorphism(s) 
did not exceed that of the post-Minas metamorphism; (2) the metamorphic grade reached during post-Nova Lima and pre-Minas metamorphism(s) exceeded that of the post-Minas metamorphism, but the post-Minas metamorphism was thorough and retrogression was complete; and (3) post-Nova Lima and pre-Minas metamorphism did not take place in the western Serra do Curral.

Mineral assemblages of the different rock types are typical of low-grade metamorphic rocks. Pelitic rocks contain chlorite, white mica, and quartz with accessory iron oxides, carbonaceous material, and carbonate; most mineral grains are less than $0.1 \mathrm{~mm}$ in diameter. Quartzites and quartz-rich rocks contain white mica and chlorite. Dolomite contains quartz, chlorite, and muscovite.

Itabirite consisting of only quartz and hematite is relatively inert to chemical changes, but higher temperatures result in increased grain size (James, 1955, p. 1473-1480). Itabirite in the western Serra do Curral contains hematite flakes only $0.06 \mathrm{~mm}$ in maximum length; these flakes generally occur mixed with smaller flakes. The average size of quartz grains is $0.04 \mathrm{~mm}$. These grain sizes occur within the chlorite zone of metamorphism of iron-formations in northern Michigan (James, 1955, p. 1462).

Some fresh itabirite contains tremolite and cummingtonite, both occurring as small bladed, acicular, and fibrous crystals, and much weathered itabirite in the Brumadinho area includes limonite pseudomorphs considered to have been derived from these amphiboles. The presence of tremolite and cummingtonite is interpreted to be the result of metamorphism of magnesian, calcic, and aluminous impurities in the pre-itabirite iron-formation to the upper part of the greenschist facies (Ramberg, 1952, p. 139-145).

Beds of iron-formation in the Nova Lima Group are more finely laminated than itabirite in the Itabira Group, but the grain sizes are the same as the smaller flakes in itabirite, $0.01-0.04 \mathrm{~mm}$. The ferruginous chlorite schist into which the iron-formations grade contains slightly larger hematite flakes and chlorite flakes as much as $0.1 \mathrm{~mm}$ in diameter.

\section{CONTACT METAMORPHISM QUARTZITE}

Three quartzite units are in contact with granitic rocks in the western Serra do Curral: (1) quartzite inclusions in Group IV granitic rocks in the Itáuna uplands; (2) quartzite of the Cercadinho Formation in contact with Group III granitic rocks on the north side of the Serra do Curral; (3) quartzite of the Moeda Formation in contact with Souza Noschese Gneiss in the Brumadinho area. None of these contacts is ex- tensively exposed. At all these places, as at the other contacts of quartzite and granite mentioned below, the gneiss has had only a slight metasomatic effect on the quartzites.

Two previously mentioned quartzite beds (p. 25) several kilometers long occur in the granitic rocks in the Itáuna uplands (pl. 3), and several others were found nearby, just west of the mapped area. Vestiges of stratification occur in some of the quartzite beds outside the area, but bedding was apparently destroyed in the quartzites within the area. At the few exposures studied, feldspathization was limited to within $2-3 \mathrm{~cm}$ of the contact.

The contact between Group III granitic rocks and quartzite of the Cercadinho Formation is exposed at only one place, where the road from Itatiaia to Itáuna passes through the water gap through the west end of the Serra do Curral (pl. 3). The three principal metamorphic effects on the quartzite are: slight feldspathization in a contact zone about $50 \mathrm{~cm}$ thick, formation of abundant white mica flakes throughout the quartzite, and the development of schistosity along bedding planes. The gneiss in contact with the quartzite is weathered, and any compositional features the gneiss might have inherited from the ferruginous quartzite were impossible to determine.

At the contact between the Souza Noschese Gneiss and quartzite of the Moeda Formation in the Rio Paraopeba water gap (pl. 1), the lower 50-60 cm of the quartzite contains large recrystallized quartz grains, and the lower $30 \mathrm{~cm}$ contains feldspar porphyroblasts on bedding planes. The gneiss contains much quartz in the 3-4 meters nearest to the contact, and this zone probably represents quartzite which has been incorporated into the gneiss.

\section{PELITIC ROCKS}

Pelitic rocks of the Nova Lima Group and Cercadinho, Fêcho do Funil, and Sabará Formations occur in contact with granitic rocks. Metamorphism of the Nova Lima Group and Sabará Formation is of a higher grade than the regional metamorphism at places along these contacts. Higher-grade metamorphism was not recognized in phyllite of the Cercadinho Formation and wdis indeterminable in the Fêcho do Funil Formation. At the few exposures of schist of the Nova Lima Group near its contact with the Souza Noschese Gneiss the schist contains garnets as much as $0.5 \mathrm{~cm}$ in diameter. The contact zone is as much as 100 meters wide.

The Sabará Formation and younger gneiss are in contact throughout most of the length of the West End area. Small garnets are abundant at many localities but are so weathered that their composition is 
uncertain. In the adjacent Ibirite quadrangle, the Sabará Formation contains a zone of staurolite schist 1 kilometer wide along its contact with younger gneiss (Pomerene, 1964, p. 28). Staurolite was not recognized in the western Serra do Curral, but garnets and quartz veins are more numerous and larger near the contact with the granitic rock. The conclusion is, therefore, that the Sabara Formation may be a thin layer over the granitic rock throughout most of the western Serra do Curral.

\section{HEMATITE SCHIST}

Several hundred meters southwest of the mapped area, the Caue Itabirite is in contact with a granitic rock. The rock, presumed to be a Group III gneissic rock because of its position, is so weathered as to be unidentifiable. At this place the Cauê Itabirite is a hematite schist consisting of hematite, muscovite, chlorite, and quartz. Most hematite flakes are 0.08 to $0.10 \mathrm{~mm}$ in diameter. Most quartz laminae have been destroyed, partly by shearing and partly, it is thought, by solution. Their remnants are represented by thin oriented discontinuous wisps and minute lenses of quartz. Foliation is well developed at a very small angle to the bedding as a result of the orientation of the specular hematite flakes, muscovite, and chlorite.

\section{IRON DEPOSITS}

Unlike most of the Quadrilátero Ferrifero where iron was mined, forged, and smelted at several places as long ago as 1811, the iron resources of the western Serra do Curral were ignored until 1911. In 1910, O. A. Derby presented a paper at the International Geologic Congress in Stockholm which attracted attention to Brazilian iron ores. The following year French, German, and English interests acquired many iron properties in Brazil. The acquisition of Córrego do Feijão at this time by the German company Stahlunion is the first recorded mining claim in the western Serra do Curral.

The first mining in the western Serra do Curral was at the Saraiva mine in the early thirties. However, general mining activity did not get under way until the 1950 's. Total production from the area through 1962 was less than 6 million tons, only a small fraction of the total reserves. The principal companies currently mining are: Mineração Geral do Brasil; Companhia de Mineração Ferro e Carvão, S.A.; Minas de Ferro, S.A.; Mineral do Brasil, Ltda.; Empresesa de Mineração Esperança, Ltda.; Minas do Paraopeba, S.A.; and Icominas, S.A. in the Brumadinho area; and J. Rabêlo, S.A., and Companhia Mineira de Siderurgia in the West End area.

Itabirite is the ultimate source of all the iron ores. Fresh itabirite in the western Serra do Curral averages 37.8 percent iron or about 54 percent hematite, and several tens of billions of tons of itabirite occur in the western Serra do Curral. Although fresh itabirite would be considered ore at many places in the world, such large deposits of higher grade natural concentrates derived from this rock exist in Brazil that fresh itabirite will have no economic value in the foreseeable future.

Redistribution of iron from itabirite by hydrothermal and weathering processes resulted in three main kinds of iron deposits. The deposits may be geologically classified according to their origin as replacement, detrital, and residual deposits. These rather closely correspond to the economic classification of high-grade, low-grade, and potential deposits, respectively.

\section{HIGH-GRADE REPLACEMENT DEPOSITS AND ORES}

High-grade replacement deposits are composed of almost pure compact, intermediate, and soft hematite. The deposits consist of irregular tabular hematite bodies occurring either alone or as a number of bodies separated from each other by several meters of itabirite. The larger bodies are as much as several hundred meters long and several tens of meters wide and are known to extend to a depth of 100 meters, the limit of exploration. Similar ore bodies in the Itabira district are known to be as much as 2,800 meters long and 150 meters thick and have been explored to a depth of 450 meters (Dorr and Barbosa, 1963, p. 65). At most places the hematite bodies parallel the bedding of the itabirite, but locally they cut across the bedding. The two largest deposits, Córrego do Feijão and Candú, are structurally controlled by folds.

High-grade ores consist of compact and soft hematite, and intergradations of these two types. The ores are generally classified into compact, intermediate, and soft ores. However, other classifications have been used such as the fourfold classification of Moraes and others (1953, fig. 3).

Compact ores (fig. 8) have an iron content only slightly less than the theoretical limit of hematite (69.94 percent). Besides hematite the ores contain isolated quartz lenses as much as several centimeters in diameter and sparse quartz grains and kaolin flakes. The average iron content of these ores is 67 percent, and 65 percent is the usual minimum grade. This is a lower iron content than that present in similar ores elsewhere in the Quadrilatero Ferrifero where the average grade is 68 percent and the usual minimum grade is 66 percent. Magnetite is a common accessory mineral and is exceptionally abundant at Córrego do Feijão, where it makes up several percent of the ore. However, the ores having the highest magnetite content contain less than 67 percent iron (table 10).

Two textural varieties of compact hematite are common: dense hematite seen in polished sections to 


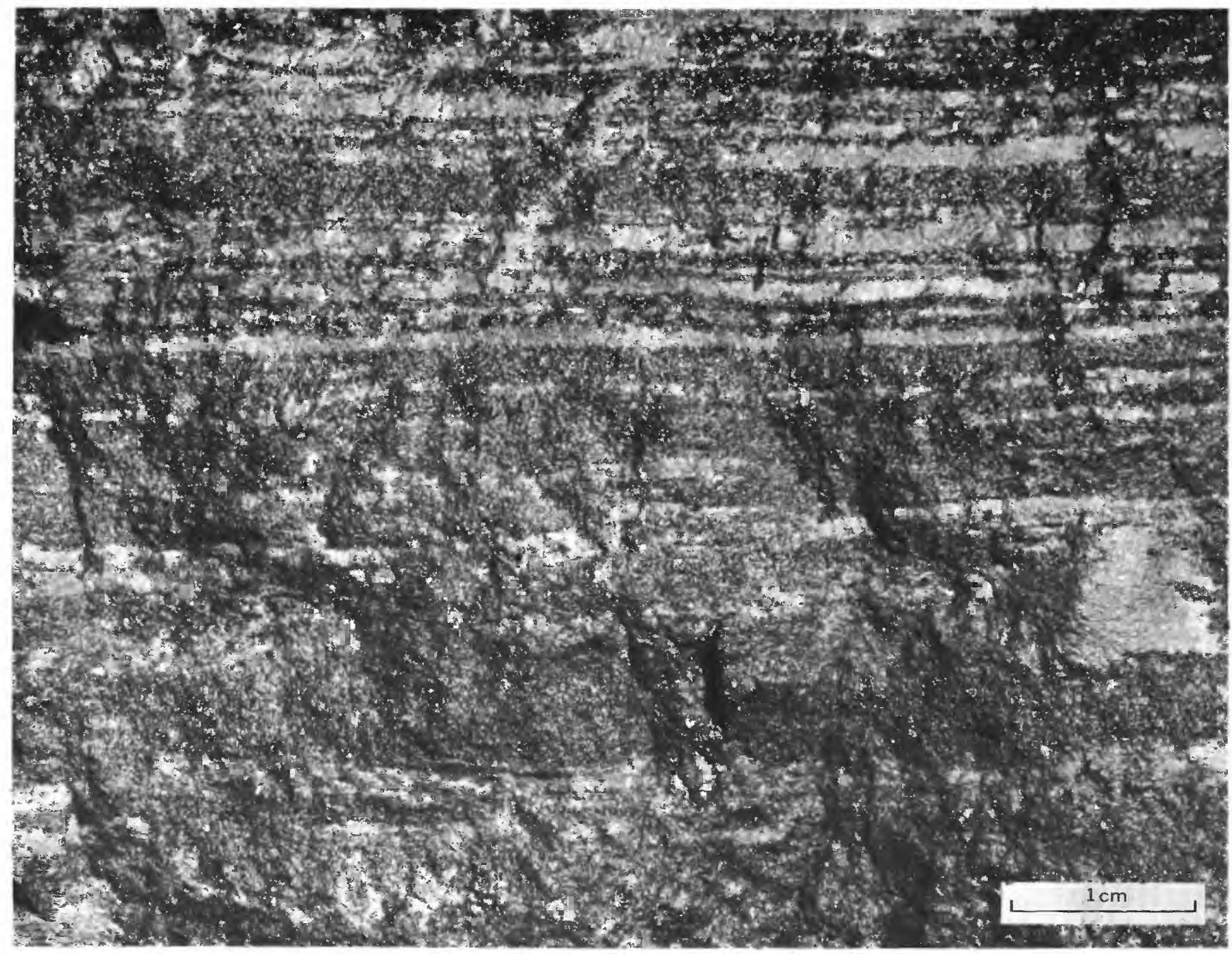

Figure 8. - High-grade compact hematite. Light laminae are composed of unoriented interlocking anhedral hematite grains; dark laminae are composed of euhedral hematite grains oriented parallel to the bedding planes. Saraiva mine.

be composed of unoriented interlocking anhedral specularite grains, and very fine grained hematite consisting of euhedral specularite grains oriented in the bedding plane. Most very fine grained hematite occurs with dense hematite as laminated hematite, which preserves the structures common in the parent itabirite (fig. $9 A$ ). Dense hematite also occurs in veins and as itabirite replacements (fig. $9 B$ ). Dense compact hematite is hard, yields a metallic ring when hit with a hammer, and breaks with a conchoidal fracture. Laminated hematite is slightly soft on bedding planes at many places and, in such places, fractures along bedding planes.

High-grade soft hematite is an incoherent ore which is soft enough to crumble into a powder when handled. Like compact hematite, soft hematite contains minor amounts of magnetite, quartz, and kaolin and has an average iron content of 68 percent. Most soft hematite contains thin laminae of dense hematite and has a structure resembling laminated hematite. However, some soft hematite is massive, resembling dense hematite. Soft hematite occurs with compact hematite, but the ratio of soft hematite to compact hematite decreases with depth. This relation was observed at the Esperança mine and was also discovered by exploration at the Córrego do Feijão deposit.

The recovery factor used in the calculation of reserves differs for compact and soft hematite ores. Hematite has a specific gravity of more than 5 . However, a recovery factor of 4.5 is used in calculating compact hematite reserves because of the fines lost during mining and handling and because of the itabirite wallrock which must be discarded in mining. A recovery factor of 4.0 is used in calculating soft hematite reserves for the same reasons and because of the porosity of the ore. 


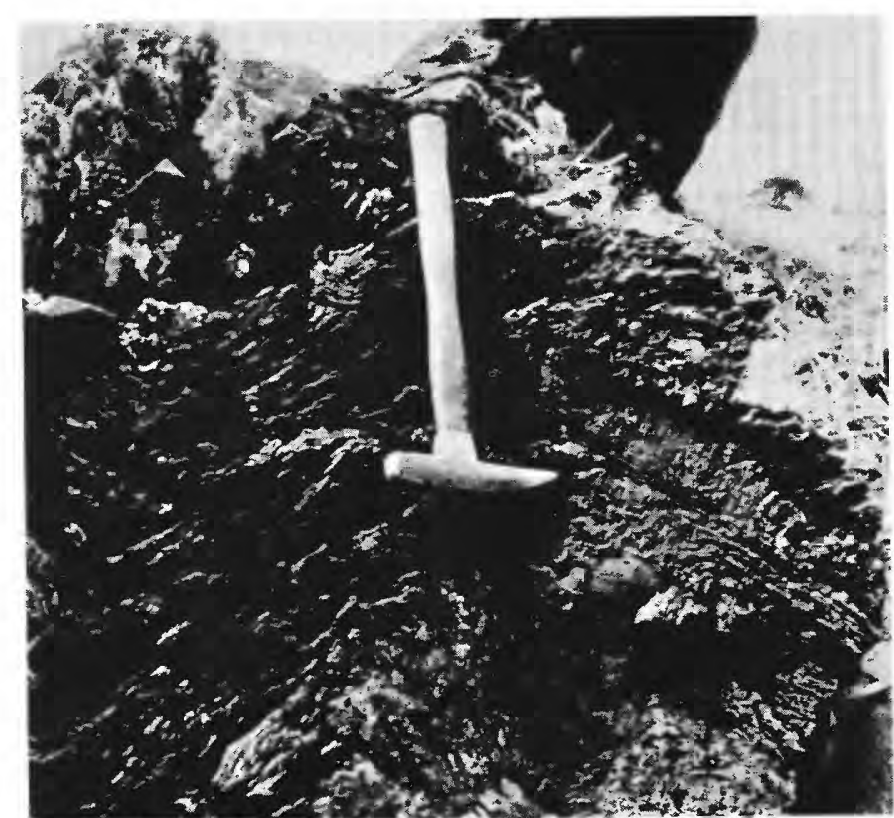

A

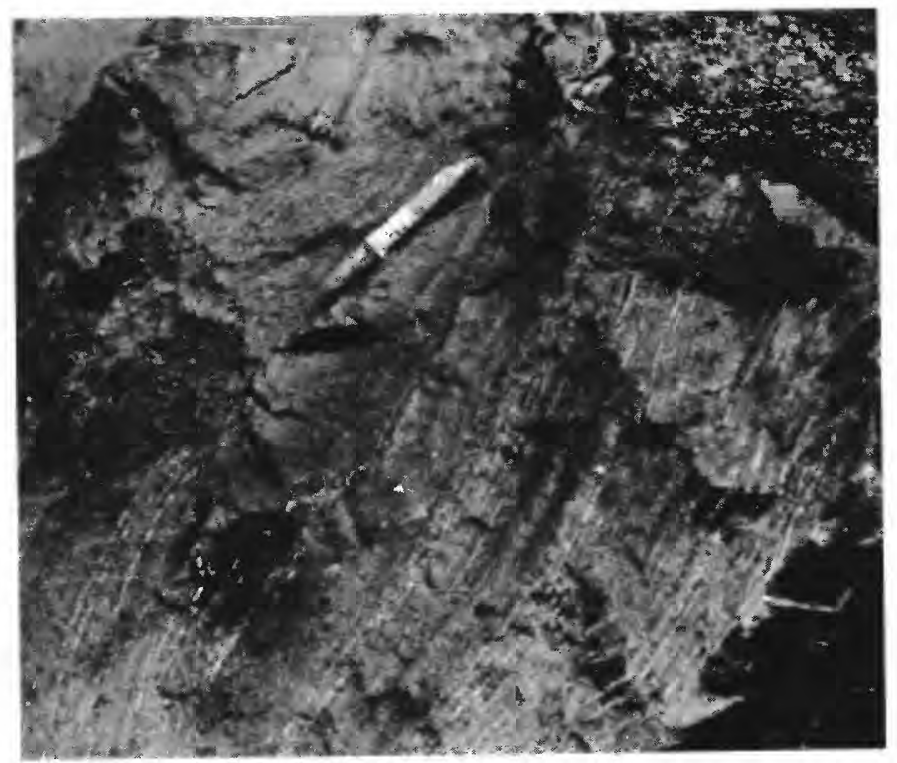

C

Origin of replacement deposits.-The origin of highgrade hematite deposits was recently discussed by Dorr and Barbosa (1963, p. 66-68), who pointed out the importance of folds as loci of major deposits. The replacement of itabirite took place during the last orogenic period, after the folding and before the thrust faulting, as the ore replaces folds and is offset by thrust faults. In the western Serra do Curral the temperature of ore deposition apparently was the same as that of the regional metamorphism; the minerals in the ore deposits are the same ones found in itabirite away from ore bodies, and the mineralogy of the

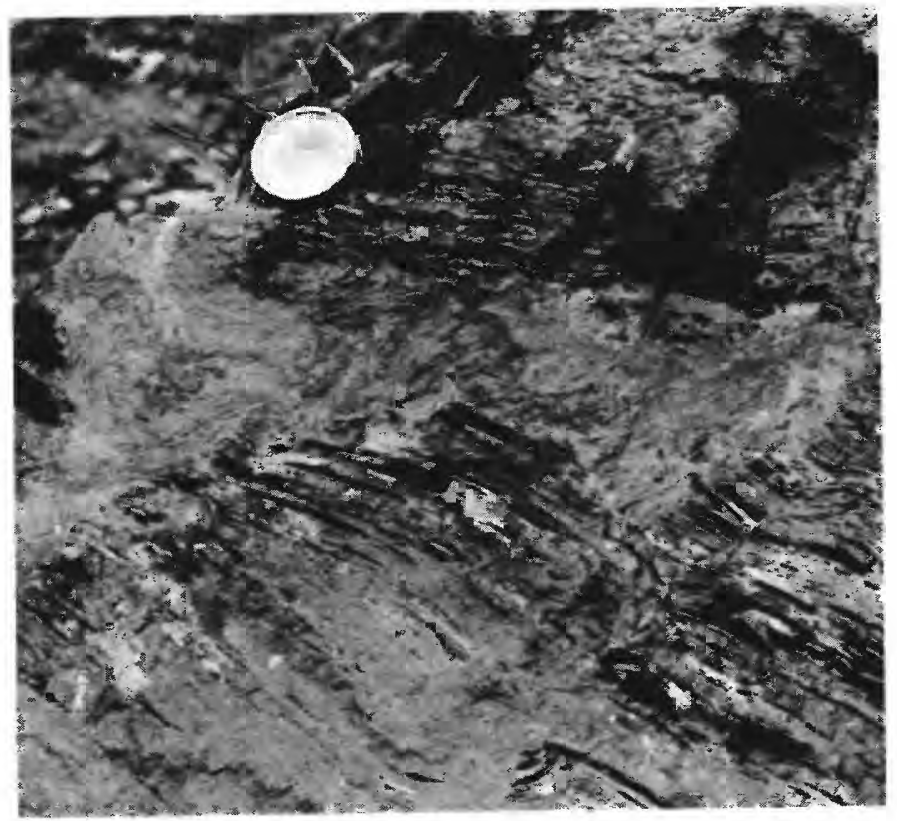

B

FIGURE 9.-Hematite replacement of itabirite. $A$, Replacement of folded itabirite, Saraiva mine. $B$, Dense-grained hematite replacement of itabirite, Saraiva mine (diameter of can is about $6 \mathrm{~cm}$ ). $C$, Incomplete compact hematite replacement of itabirite, Candú mine. Discontinuous light bands are remains of quartz-rich laminae. formations adjacent to ore bodies is the same as the mineralogy of those formations away from ore bodies. The author does not concur with the hypothesis (Dorr and Barbosa, 1963, p. 68-74) that the fluids responsible for the replacement of quartz in itabirite by hematite came from nearby granitic rocks because no extrinsic minerals occur either in the ore in contiguous parts of the Caue Itabirite or in the Batatal and Gandarela Formations where they are exposed adjacent to ore bodies. Instead, the author thinks that the water probably came from the proto-itabirite. The author agrees with all recent writers that the iron 
which replaced the quartz came from itabirite and not from an extraneous source (fig. 9c). As stated above, the distribution and relation between hard and soft ore, the latter more common near the present erosion surface and grading downward into harder ore, strongly suggest that the soft ore developed by weathering of the hard ore; most writers agree on this hypothesis.

\section{DETRITAL DEPOSITS AND ORES}

Detrital deposits contain compact hematite and itabirite colluvium. They form surficial blankets from several centimeters to several meters thick, and extend as much as several kilometers downslope from their source, the Cauê Itabirite, at the crest of the Serra do Curral. Detrital deposits overlie Souza Noschese Gneiss and every stratified rock unit in the Serra do Curral except the Nova Lima Group. Where detrital deposits are unconsolidated they are called rolado, where cemented by limonite they are called canga (p. 22). Detrital deposits also include rolado composed of canga blocks, and at Córrego do Feijão they include an alluvial deposit.

The iron content of detrital deposits is to a large extent dependent upon the amount of compact hematite contained, and higher grade deposits contain as much as 68 percent iron. The high percentage reported for some rolado deposits can be misleading because analyses are made only after earth and fine materials are discarded, and thus analyses are made only of hard hematite fragments. As a result of the varying quantities discarded in mining rolado deposits, recovery factors of from 1.5-3.0 are used in calculating ore reserves. Factors of 2.5-3.0 are used for canga.

The detrital deposits range in quality from those which are equal to some replacement deposits through those of lower grade to those which are presently uneconomical. Some rolado ores, such as those from the Tijuco rolado deposit, are equal in quality and tonnage to small replacement bodies and are easier to mine. Some canga-rica deposits, such as occur at Córrego do Feijão, are also desirable because the porosity of the material facilitates smelting. However, most mined detrital deposits contain more itabirite than compact hematite, and although no lower limit of iron content has been established for separating ore from sub-ore, material containing 60 percent iron is about the lowest grade oridinarily mined. Rolado and canga ores average between 62 and 64 percent iron.

\section{RESIDUAL DEPOSITS, ORES, AND POTENTIAL ORES}

Three gradational types of potential ores which are presently mined under certain conditions result from the chemical weathering of itabirite in place. These are structure canga, enriched itabirite, and soft itabirite.
Structure canga is itabirite from which most of the quartz has been leached, in which most hematite has been hydrated to limonite, and which is enriched by limonite. Structure canga preserves the original attitude of the itabirite bedding, but at many places it can not be distinguished from canga containing detrital itabirite. Both cangas have the same range in grade and recovery factors, and from an economic point of view, the two rocks are identical.

Enriched itabirite is transitional between structure canga and soft itabirite. The enriched rock is itabirite from which much silica has been leached. The hydration of hematite and enrichment of limonite occurs in this rock but is not sufficient to completely consolidate the weathered itabirite, as occurs in structure canga.

Enriched itabirite overlies most of the Cauê Itabirite in the western Serra do Curral. Only the most resistant itabirites and those which have recently been mechanically eroded have no covering of enriched itabirite. Much enriched itabirite is covered by structure canga but is exposed at many places along eroded canga rims and in mine cuts. The itabirite ranges in thickness from a few centimeters to 10 meters but averages 1 meter.

Enriched itabirite is estimated to contain about 55 percent iron, or 10 percent more iron than unweathered itabirite contains. This is similar to the $55+$ percent figure used in calculating the enriched itabirite reserves of the Congonhas district (Guild, 1957 , p. $67-69)$. Enriched itabirite is mined at only a few places because of the presence of large quantities of higher grade ores in the Quadrilatero Ferrifero. With the exception of one small mining operation at the west end of the Serra do Barreiro, all mined enriched itabirite from the western Serra do Curral was extracted because of its association with canga and because it could be handled in the same manner as canga. Nevertheless, large tonnages of enriched itabirite, which are potential ore, are present.

Soft itabirite is itabirite from which quartz has been leached. Because it is present in such large tonnages and is easy to mine and concentrate, soft itabirite is a potential source of more iron than all other ores in the Quadrilatero Ferrifero. The tenor of soft itabirite ranges from that of fresh itabirite (about 35 percent iron) to that of nearly pure hematite (about 65 percent iron). Soft itabirite in the western Serra do Curral is estimated to average 50 percent iron. Most itabirite in the western Serra do Curral has been softened to a depth of more than 50 meters, and such thicknesses are exposed on the sides of steep drainage heads at many places in the range. The maximum depth to which softening occurs is unknown. Guild (1957, p. 45) 
reported weathered itabirite at a depth of 220 meters, and softening probably occurs from the surface to the water table.

Some disagreement exists as to the exact process of softening. Dorr and Barbosa (1963, p. 26-30) believed that much of the hard itabirite exposed at the surface is the rock from which soft itabirite is formed. Pomerene $(1964$, p. 44$)$ thought that soft itabirite results from leaching of a different itabirite, one that differs in a combination of carbonate content, grain size, and distribution of hematite and quartz.

\section{RESERVES}

Total iron resources of the western Serra do Curral include nearly 120 million tons of indicated and inferred reserves of high- and low-grade ores and more than 1,600 million tons of potential resources. Indicated reserves of high-grade ores averaging 67 percent iron include 11 million tons of compact hematite and 13 million tons of soft hematite. Indicated reserves of low-grade ores include 51 million tons of canga averaging 62 percent iron and 8 million tons of rolado averaging 61 percent iron. Inferred reserves include 17 million tons of compact hematite and 19 million tons of soft hematite, both averaging 67 percent iron. Potential resources include 35 million tons of enriched itabirite estimated to contain 55 percent iron and 1,600 million tons of soft itabirite estimated to contain 50 percent iron. Indicated and inferred reserves are listed in summary form in table 7 according to type and mine or area in which they occur. The same reserves are listed in table 8 in more detailed form according to the mine or the area in which they occur; the data include dimensions, recovery factor, and grade of the ores. Potential resources are listed in table 9 according to the section of the Serra do Curral in which they occur.

Indicated reserves of compact and soft hematite were computed from surface areas measured on maps with a planimeter and from vertical distances lying above the lowest exposures of the ore bodies. Inferred reserves of compact and soft hematite were calculated in terms of tons per meter of depth and projected to a depth of 50 meters. Ore was not projected where geologic data indicated lack of downward continuity; this condition prevails in part of the Candu mine where the flat-lying base of the Cauê Itabirite immediately underlies some of the mine workings. Other deviations from this procedure are noted where used under the description of the individual deposit. The recovery factors used in calculating all tonnages are either those used by the mining companies or are figures within the range used by mining companies and are based on specific-gravity determinations.

TABLE 7.-Indicated and inferred iron reserves of the western Serra do Curral

[Reserves in metric tons]

\begin{tabular}{|c|c|c|c|c|c|c|c|c|c|}
\hline \multirow[t]{2}{*}{ Area or mine } & \multicolumn{4}{|c|}{ Indicated reserves } & \multirow{2}{*}{ Total } & \multicolumn{2}{|c|}{$\begin{array}{l}\text { Inferred reserves } \\
\text { (per } 50 \text { meters depth) }\end{array}$} & \multirow{2}{*}{ Total } & \multirow{2}{*}{$\begin{array}{l}\text { Indicated } \\
\text { and inferred } \\
\text { reserves: } \\
\text { Grand } \\
\text { total }\end{array}$} \\
\hline & $\begin{array}{l}\text { Compact } \\
\text { hematite }\end{array}$ & $\begin{array}{c}\text { Soft } \\
\text { hematite }\end{array}$ & Canga & Rolado & & $\begin{array}{l}\text { Compact } \\
\text { hematite }\end{array}$ & $\begin{array}{c}\text { Soft } \\
\text { hematite }\end{array}$ & & \\
\hline \multicolumn{10}{|l|}{ Brumadinho area: } \\
\hline Córrego do Feijão & $9,500,000$ & ${ }^{1} 13,000,000$ & 2420,000 & 3150,000 & $23,000,000$ & $14,000,000$ & ${ }^{4} 18,000,000$ & $32,000,000$ & $55,000,000$ \\
\hline Serradão- & - & - & $2,200,000$ & $1,500,000$ & $3,700,000$ & -20000 & …-......-. & -...-. & $3,700,000$ \\
\hline Pico dos Tres Irmãos . . . & -........... & - n............ & $2,400,000$ & $2,000,000$ & $2,400,000$ & ............ & - & - & $2,400,000$ \\
\hline Laranjeiras . . . . & -............. & - & 120,000 & 100,000 & 220,000 & - n & 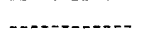 & -............... & 220,000 \\
\hline Bocaina area...... & - & - & 600,000 & 300,000 & 900,000 & 550,000 & 700,000 & $1,200,000$ & $2,100,000$ \\
\hline Tijuco canga deposit. & -............ & - & $5,600,000$ & $2,500,000$ & $8,100,000$ & - & - n & ........... & $8,100,000$ \\
\hline Tijuco rolado deposit. & n.............. & -............ & 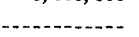 & $1,600,000$ & $1,600,000$ & - n & -............. & - & $1,600,000$ \\
\hline Serra do Fecho do Funil & n.- & - & 960,000 & -............ & 960,000 & - & $-\ldots$ & -............. & 960,000 \\
\hline Souza Noschese & - - n-n-n & -.............. & 240,000 & (n............ & 240,000 & - n- & - & 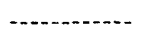 & 240,000 \\
\hline Candú area & $1,100,000$ & 68,000 & 72,000 & 170,000 & $1,400,000$ & $2,200,000$ & 260,000 & $2,500,000$ & $3,900,000$ \\
\hline Serra das Farofas . . . & -............ & -.............. & $2,800,000$ & 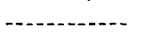 & $2,800,000$ & -............. & ............... & - - & $2,800,000$ \\
\hline Pau de Vinho & 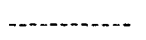 & -.............. & 390,000 & - n & 390,000 & - & 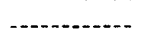 & 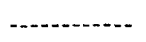 & 390,000 \\
\hline Total & $11,000,000$ & 13,000000 & $16,000,000$ & $6,300,000$ & $46,000,000$ & $17,000,000$ & $19,000,000$ & $36,000,000$ & $82,000,000$ \\
\hline \multicolumn{10}{|l|}{ West End area: } \\
\hline Serra do Mantiqueira-Serra do Barreiro _. & - & - n- & $11,000,000$ & 900,000 & $12,000,000$ & & & & $12,000,000$ \\
\hline Serra do Itatiaia & - & - & $9,600,000$ & 400,000 & $10,000,000$ & 180,000 & - n & 180,000 & $10,000,000$ \\
\hline Serra Azul & - n........... & - - n-n.-. & $14,000,000$ & 400,000 & $14,000,000$ & - & - n & -............ & $14,000,000$ \\
\hline Total & - n & -............ & $35,000,000$ & $1,700,000$ & $36,000,000$ & 180,000 & -............. & 180,000 & $36,000,000$ \\
\hline Grand total & $11,000,000$ & $13,000,000$ & $51,000,000$ & $8,000,000$ & $82,000,000$ & $17,000,000$ & $19,000,000$ & $36,000,000$ & $118,000,000$ \\
\hline Average grade (percent iron) & 67 & 567 & 62 & 61 & 63 & 67 & 67 & 67 & 64 \\
\hline
\end{tabular}

1 Includes 2,000,000 tons of soft itabirite.

2 Includes rolado.

${ }^{4}$ Includes 2,000,000 tons of soft itabirite.

3 Alluvial ore of compact hematite. 
TABLE 8.-Indicated and inferred iron reserves in the western Serra do Curral by deposit and mine area

\begin{tabular}{|c|c|c|c|c|c|c|c|c|c|}
\hline & \multirow[b]{2}{*}{$\begin{array}{c}\text { Area } \\
\text { (square } \\
\text { meters) }\end{array}$} & \multirow{2}{*}{$\begin{array}{l}\text { Thickness } \\
\text { (meters) }\end{array}$} & \multirow[b]{2}{*}{$\begin{array}{c}\text { Volume } \\
\text { (cubic } \\
\text { meters) }\end{array}$} & \multirow{2}{*}{$\begin{array}{l}\text { Specific } \\
\text { gravity } 1\end{array}$} & \multirow[b]{2}{*}{$\begin{array}{c}\text { Grade } \\
\text { (percent } \\
\text { iron) })^{2}\end{array}$} & \multirow[b]{2}{*}{$\begin{array}{l}\text { Indicated } \\
\text { reserves } \\
\text { (metric tons) }\end{array}$} & \multicolumn{2}{|c|}{ Inferred reserves } & \multirow{2}{*}{$\begin{array}{c}\text { Total } \\
\text { reserves } \\
\text { (metric tons) }\end{array}$} \\
\hline & & & & & & & $\begin{array}{c}\text { Metric tons } \\
\text { per meter } \\
\text { of depth }\end{array}$ & $\begin{array}{c}\text { Metric tons } \\
\text { 50-meter } \\
\text { depth }\end{array}$ & \\
\hline \multicolumn{10}{|l|}{$\begin{array}{l}\text { Brumadinho area: } \\
\text { Córrego do F eljão: }\end{array}$} \\
\hline Soft hematite & 80,000 & 100 & ${ }^{3} 2,800,000$ & 4.0 & 67 & $11,000,000$ & 320,000 & $16,000,000$ & $27,000,000$ \\
\hline Compact hematite & 64,000 & 100 & $82,100,000$ & 4.5 & 67 & $9,500,000$ & 290,000 & $14,000,000$ & $24,000,000$ \\
\hline Soft itabirite. & 16,000 & 100 & 3530,000 & 3.0 & 62 & $1,600,000$ & 48,000 & $2,400,000$ & $4,000,000$ \\
\hline Canga and rolado & 140,000 & 1.0 & 140,000 & 3.0 & 67 & 420,000 & $\ldots$ & -............ & 420,000 \\
\hline Alluvial............................... & 50,000 & 1.0 & 50,000 & 3.0 & 66 & 150,000 & (n.............. & n........... & 150,000 \\
\hline 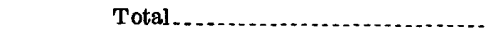 & (n................. & - & n. & n. & (n............... & $23,000,000$ & - & $32,000,000$ & $55,000,000$ \\
\hline \multicolumn{10}{|l|}{ Serradão: } \\
\hline Canga & 750,000 & 1.0 & 750,000 & 3.0 & 61 & $2,200,000$ & - & (n) & $2,200,000$ \\
\hline Rolado & 750,000 & 1.0 & 750,000 & 2.0 & 69 & $1,500,000$ & ................ & . n & $1,500,000$ \\
\hline Total ............... & ...... & $\cdots-$ & - n & $\cdots$ & $\cdots$ & $3,700,000$ & -...- & -.......... & $3,700,000$ \\
\hline \multicolumn{10}{|l|}{ Pico dos Tres Irmăos: } \\
\hline $\begin{array}{l}\text { Canga } \\
\text { Laranjeiras: }\end{array}$ & 400,000 & 2.0 & 800,000 & 3.0 & 60 & $2,400,000$ & .................. & - n & $2,400,000$ \\
\hline Canga & 40,000 & 1.0 & 40,000 & 3.0 & 55 & 120,000 & - n. & - n. & 120,000 \\
\hline 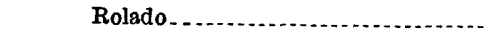 & 40,000 & 1.0 & 40,000 & 2.5 & 55 & 100,000 & -............. & ............ & 100,000 \\
\hline Total & $\cdots$ & $\cdots$ & - n. & $\cdots$ & & 220,000 & $\cdots$ & ..... & 220,000 \\
\hline \multicolumn{10}{|l|}{ Bocaina: } \\
\hline Canga & 130,000 & 1.5 & 200,000 & 3.0 & 66 & 600,000 & $\ldots$ & & 600,000 \\
\hline Rolado & 100,000 & 1.5 & 150,000 & 2.0 & 68 & 300,000 & ........... & ............... & 300,000 \\
\hline Soft hematite. & 3,400 & $\ldots$ & . . . & 4.0 & 68 & .............. & 14,000 & 700,000 & 700,000 \\
\hline Compact hematite. & 2,500 & - & - & 4.5 & 68 & (............. & 11,000 & 550,000 & 550,000 \\
\hline 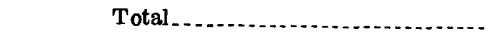 & $-\ldots$ & $\cdots$ & (n) & $\ldots$ & $\ldots$ & 900,000 & .... & $1,200,000$ & $2,100,000$ \\
\hline \multicolumn{10}{|l|}{ Tijuco canga deposit: } \\
\hline Canga & $1,250,000$ & 1.5 & $1,880,000$ & 3.0 & 58 & $5,600,000$ & $\ldots$ & - n. & $5,600,000$ \\
\hline Rolado & $1,250,000$ & 1.0 & $1,250,000$ & 2.0 & $\mathbf{5 5}$ & $2,500,000$ & - & (............... & $2,500,000$ \\
\hline Total & (n.......... & $\ldots$ & - n. & ..... & (n) & $8,100,000$ & ...... & - & $8,100,000$ \\
\hline \multicolumn{10}{|l|}{ Tijuco rolado deposit: } \\
\hline $\begin{array}{l}\text { Rolado } \\
\text { Serra do Focho do Funil: }\end{array}$ & 200,000 & 4. 0 & 800,000 & 2.0 & 66 & $1,600,000$ & (n) & (................ & $1,600,000$ \\
\hline Canga. & 160,000 & 2.0 & 320,000 & 3.0 & 60 & 960,000 & .... & ........... & 960,000 \\
\hline \multicolumn{10}{|l|}{ Souza Noschese: } \\
\hline Canga............. & 40,000 & 2.0 & 80,000 & 3.0 & $\mathbf{5 5}$ & 240,000 & $\ldots . .$. & - n & 240,000 \\
\hline \multicolumn{10}{|l|}{ Candú area: } \\
\hline Compact hematite & 10,000 & 425 & 250,000 & 4.5 & 67 & $1,100,000$ & 45,000 & $2,200,000$ & $3,300,000$ \\
\hline Rolado (crest) & 50,000 & 1.0 & 50,000 & 1.5 & 68 & 75,000 & 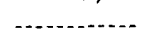 & -.............. & 75,000 \\
\hline Rolado (upper slope) & 30,000 & 1.0 & 30,000 & 2.0 & 68 & 60,000 & (n) & .............. & 60,000 \\
\hline Rolado (lower slope) & 15,000 & 1.0 & 15,000 & 2.5 & 68 & 38,000 & ............. & ............. & 38,000 \\
\hline Canga. & 12,000 & 2.0 & 24,000 & 3.0 & 64 & 72,000 & - & ............. & 72,000 \\
\hline Soft hematite & 1,300 & 40 & 317,000 & 4.0 & 68 & 68,000 & 5,200 & 260,000 & 330,000 \\
\hline Total & - n. & .... & - & $\cdots$ & & $1,400,000$ & (n. & $2,500,000$ & $3,900,000$ \\
\hline \multicolumn{10}{|l|}{ Serra das Farofas: } \\
\hline Canga...................... & 460,000 & 2.0 & 920,000 & 3.0 & 57 & $2,800,000$ & . & - & $2,800,000$ \\
\hline \multicolumn{10}{|l|}{ Pau de Vinho: } \\
\hline Canga & 65,000 & 2.0 & 130,000 & 3.0 & 64 & 380,000 & (n) & .............. & 390,000 \\
\hline Total Brumadinho area ................ & (n) & $\cdots$ & ......... & $\ldots$ &.- & $46,000,000$ & -...... & $36,000,000$ & $82,000,000$ \\
\hline $\begin{array}{l}\text { West End area: } \\
\text { Serra do Mantiqueira-Serra do Barreiro: }\end{array}$ & & & & & & & & & \\
\hline Canga & $1,800,000$ & 2.0 & $3,600,000$ & 3.0 & 58 & $11,000,000$ & . & , & $11,000,000$ \\
\hline Rolado & 450,000 & 1.0 & 450,000 & 2.0 & 58 & 900,000 & (n........... & (............. & 900,000 \\
\hline Total & ..... & .... & - & .... & & $12,000,000$ & $\ldots$. & $\ldots$ & $12,000,000$ \\
\hline
\end{tabular}

Footnotes at end of table. 
TABLE 8.-Indicated and inferred iron reserves in the western Serra do Curral by deposit and mine area-Continued

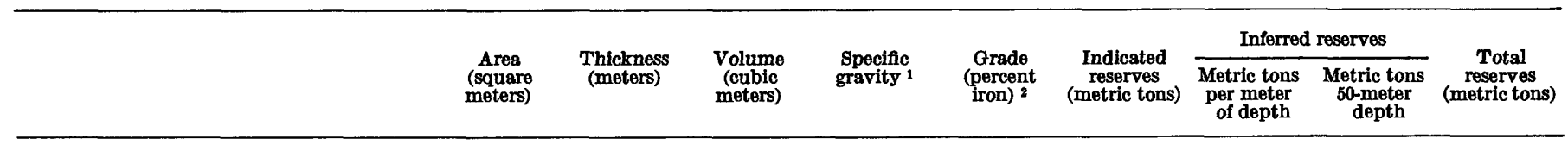

West End area-Continued

Serra do Itatiaia:

Canga

Rolado . . . . .

Compact hematite...................

Total.

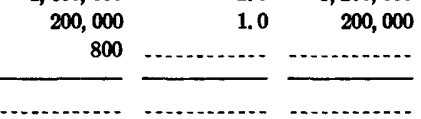

2.0

Serra Azul:

Canga.

Rolado
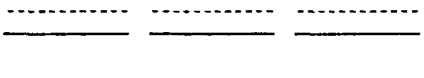

$\overline{\ldots \ldots \ldots}$

28

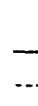

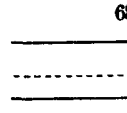

$63 \quad 9,600,000$

400,000

(1)

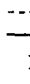

3,600

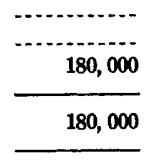

$8,600,000$

.............

180,000

$10,000,000$
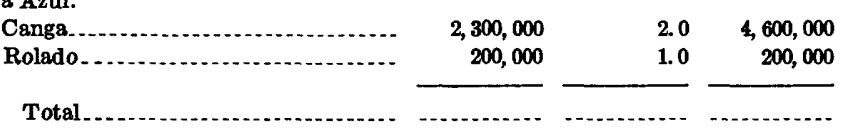

Total West End area.
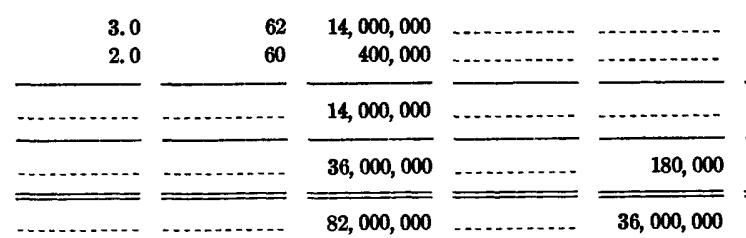

$14,000,000$ 400,000

$14,000,000$

Grand total

(n............

(2...........

1 Recovery factor based on specific gravity.

2 Based on analyses and estimates.

TABLE 9.-Potential iron resources in the western Serra do Curral [In metric tons]

\begin{tabular}{|c|c|c|c|}
\hline & $\begin{array}{c}\text { Area } \\
\text { (square } \\
\text { meters) }\end{array}$ & $\begin{array}{l}\text { Enriched } \\
\text { itabirite } 1\end{array}$ & $\begin{array}{c}\text { Soft } \\
\text { itabirite } 2\end{array}$ \\
\hline \multicolumn{4}{|l|}{ Brumadinho area: } \\
\hline Serra dos Tres Irmaos 3 & $1,200,000$ & $3,800,000$ & $180,000,000$ \\
\hline Serra do Fecho do Funil.............. & 650,000 & $2,100,000$ & $98,000,000$ \\
\hline Serra das Farofas & 620,000 & $2,000,000$ & $94,000,000$ \\
\hline Total Brumadinho area... & & $8,000,000$ & $370,000,000$ \\
\hline \multicolumn{4}{|l|}{ West End area: } \\
\hline $\begin{array}{l}\text { Serra da Mantiqueira-Serra do Bar- } \\
\text { reiro }\end{array}$ & $1,400,000$ & $4,500,000$ & $210,000,000$ \\
\hline Serra do Itatiaia...... & $1,300,000$ & $4,300,000$ & $200,000,000$ \\
\hline Serra Azul & $5,600,000$ & $18,000,000$ & $840,000,000$ \\
\hline Total West End area & $\ldots$ & $27,000,000$ & $1,200,000,000$ \\
\hline Grand total & & $35,000,000$ & $1,600,000,000$ \\
\hline Average grade (percent íron) & & 55 & 50 \\
\hline
\end{tabular}

1 Calculated for an average depth of 1 meter using a recovery factor of 3.2 tons per cubic meter.

${ }^{2}$ Calculated for an average depth of 50 meters using a recovery factor of 3.0 tons per cubic meter.

3 Includes only that part of the Serra dos Tres Irmaos within the Brumadinho area.

All canga and rolado deposits are classified as indicated reserves because their surfaces are always either exposed or evident from the topography and their vertical extent is known from natural exposures, mining excavations, and test pits. Although some canga and rolado deposits are high-grade ores and others are only potential reserves, the majority of deposits are low-grade ores, and all canga and rolado have been included in this ore group. A more exact classification of individual deposits would entail many detailed sampling programs. As time was not available for such
3 Computed as volume of a cone.

1 Weighted average of hematite lenses.

sampling and the general interest of mining companies in canga ores has not been sufficient to carry out such programs, the variation of canga deposits is not well known. The grouping of all canga and rolado deposits as low-grade ores is, then, a grouping for convenience.

Potential resources of enriched and soft itabirite were calculated by measuring the area of the Cauê Itabirite which is not hard itabirite. A large part of the measured area is covered by canga, but numerous exposures on the steep sides of the Serra do Curral show that almost all such canga overlies an average thickness of 1 meter of enriched itabirite and an average of at least 50 meters of soft itabirite. In addition, enriched itabirite has a wider distribution than canga, and sof $t$ itabirite has a slightly wider distribution than the enriched itabirite. The difference between the areas covered by enriched itabirite and soft itabirite was not noted in mapping, but the difference is not great, and the same figure was used for both calculations. Enriched itabirite and soft itabirite in the Gandarela Formation are not included in the calculations. Average thicknesses of 1 and 50 meters and recovery factors of 3.2 and 3.0 tons per cubic meter were used for enriched and soft itabirite, respectively.

\section{BRUMADINHO AREA CÓRREGo do FEIJÃo}

The Córrego do Feijão deposits consist of a high-grade compact and soft hematite ore body with associated canga rica, rolado, and alluvial ores, rolado and canga ores in part of a pediment extending 2.5 kilometers south of the hematite body, and canga north of the compact and soft hematite ore body. Only the compact and soft hematite ore body and associated ores are 
discussed in this section. They are near N. 9,400, E. 12,400 , on plate 1 and appear in more detail in figure 10. For convenience, the Córrego do Feijão pediment ores are described with the Serradão deposit, which contains the remainder of the rolado and canga ores in the other part of the pediment; the canga north of the ore body is discussed with canga near Pico dos Tres Irmãos. The Córrego do Feijão deposits are owned and presently (January 1962) being explored by Companhia de Mineração Ferro e Carvão, S. A., a subsidiary of the German company Stahlunion. An all-weather road links the deposits with the railroad loading station at Alberto Flôres, 9 kilometers away.

The Córrego do Feijão hematite body crops out on a hill having an elliptical base, a 600 -meter-long east-west axis, and a 300 -meter-long north-south axis. The hilltop is a terracelike step 100 meters below and 400 meters south of the Serra do Curral crest. The hill is 100 meters high; its base is at an altitude of 1,140 meters and its top at 1,240 meters. Most of the hill is covered by canga rica and by rolado derived from this canga. However, a number of small compact hematite outcrops protrude a meter or two above these surficial ores. On the south and west sides, the canga and rolado are bordered by areas covered with pebbles and cobbles of compact hematite.

The Córrego do Feijão deposit was mapped in November 1958. Since that time, a new road opened a few exposures near the base of the Minas Series, and three exploration tunnels were driven, two of them into the ore body. The new exposures were visited briefly in January 1962, and information gathered at that time is included in this discussion but not shown on the deposit map (fig. 10).

Excluding surficial ores, the deposit occurs in the lower part of the Caue Itabirite at the intersection of two fold axes. One fold is an isoclinal syncline parallel to the south limb of the Piedade syncline. The other is a cross-range syncline open to the north, the axis striking approximately N. $15^{\circ} \mathrm{W}$. Post-ore compression has fractured and sheared the ore body along one and possibly several thrust faults believed to have a displacement of about 10 meters.

Six types of ore occur on the property: compact hematite, soft hematite, soft itabirite, canga rica, slumped canga and rolado, and alluvial pebbles and cobbles of compact hematite. All the ores are magnetic, although no magnetite was seen in hand specimens. The compact hematite exists in three intergradational subtypes: a dense grayish-blue structureless hematite yielding a conchoidal fracture, a dense grayish-blue hematite having relic contorted bedding, and a dense grayish-blue hematite having relic bedding and minute cavities that yields a red powder when struck with a hammer. The surface of the latter subtype is deeply etched so that it appears to be composed of breccia fragments; from a distance it looks like canga. All three compact hematites contain about 67 percent iron.

Soft hematite and soft itabirite, seen only in exploration drifts where they are interbedded with compact hematite, underlie much of the canga rica, slumped canga, and rolado. The pebbles and cobbles of compact hematite are mostly subangular and occupy ephemeral drainage channels. They have obviously been transported only a few tens of meters, but water has apparently removed all the finer grained detritus. The soft hematite and compact hematite pebbles and cobbles average about 67 percent iron, the soft itabirite averages 62 percent iron, and the canga rica and rolado about 66 percent iron. Analyses of samples cut from two drifts are listed in table 10; most of the same analyses are summarized in table 11 , where they can be compared with analyses of iron ores from other parts of the western Serra do Curral.

The Córrego do Feijão deposit is explored by three drifts and several shallow pits. Two of the drifts enter the compact and soft hematite ore body on its south side near the base of its exposure. The third drift was started at a slightly lower altitude in the Moeda Formation. The No. 1 and No. 2 drifts, 340 and 240 meters long, respectively, in January 1962, are entirely within the Cauê Itabirite. About 90 percent of the Cauê Itabirite found in the drifts was replaced by compact hematite. More than half of the compact hematite has been weathered to soft hematite, and nearly all the remaining itabirite has been weathered to soft itabirite. On this basis it is estimated that the upper 100 meters of the ore body is 50 percent soft hematite, 40 percent compact hematite, and 10 percent soft itabirite. This represents a considerably higher ratio of compact to soft hematite than is indicated at the surface, where compact hematite crops out over less than 10 percent of the ore body. The No. 3 drift, about 45 meters long, was started in the Moeda Formation and was abandoned in the Batatal Formation as a result of high water saturation and continual caving. Test pits in canga, rolado, and alluvial ores indicate that these surficial ores have a depth of 1 meter.

Reserves of all ores total 55 million tons, of which indicated reserves are 23 million tons and inferred reserves are 32 million tons. Indicated reserves of compact hematite, soft hematite, and soft itabirite are considered those above the level of the two principal drifts, which coincide with the lowest level of outcrops. The ores are in a hill having an elliptical base of 160,000 

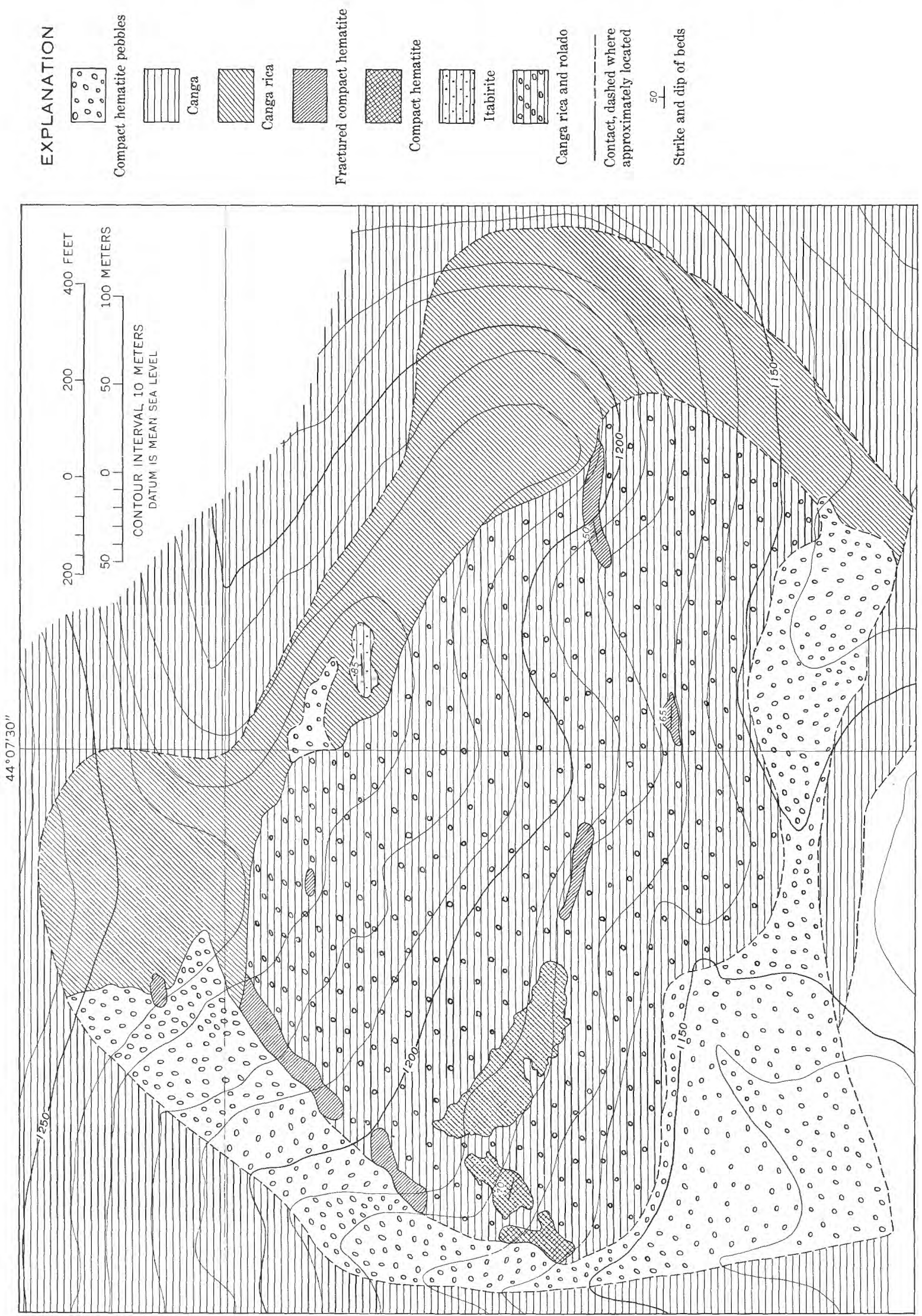

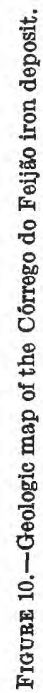


TABLe 10.-Analyses, in percent, of successive intervals sampled in Corrego do Feijäo exploration drifts [Analyses provided by Companhia de Mineração Ferro e Carvão, S.A. Analyst unknown. Width of intervals unstated. n.d., not determined]

\begin{tabular}{|c|c|c|c|c|c|c|c|c|c|c|c|}
\hline Sample & & $\mathrm{Fe}$ & $\mathrm{FeO}$ & $\mathrm{Fe}_{2} \mathrm{O}_{3}$ & Mn & $\mathbf{P}$ & $\mathrm{SiO}_{2}$ & $\mathrm{Al}_{2} \mathrm{O}_{3}$ & $\mathrm{CaO}$ & MgO & $\mathrm{H}_{2} \mathrm{O}^{-}$ \\
\hline \multicolumn{12}{|c|}{ Drift 1} \\
\hline 1 & Soft itablrite and compact hematite & 52.87 & 0.19 & 75.33 & 1.45 & 0.075 & 17.85 & 2.25 & 0.05 & 0.05 & 2. 10 \\
\hline 2 & Compact hematite and soft itabirite & 65.20 & 5.25 & 87.40 & .17 & .055 & 5.15 & .65 & .05 & .05 & 1.00 \\
\hline 3 & Compact hematite and soft itabirite & 61.64 & 4.65 & 82.97 & .65 & .082 & 7.10 & 2.00 & .05 & .10 & 2. 00 \\
\hline 4 & Compact hematite. & 65.15 & 2.10 & 90.85 & .10 & .076 & 3.25 & .75 & .05 & .10 & 2.45 \\
\hline 5 & Compact hematite and soft itabirite & 65.84 & 1.92 & 92.02 & 1.00 & .051 & 2.00 & 1.10 & .05 & n.d. & 1.35 \\
\hline 6 & Soft and compact hematite & 67.41 & .76 & 95.55 & .21 & .033 & 1.45 & .90 & .05 & n.d. & .80 \\
\hline 7 & Argillaceous material on fractures in compact hematite & 59.30 & .26 & 84.51 & 2.23 & .063 & 5.21 & 3.98 & .05 & n.d. & 2.86 \\
\hline 8 & Compact hematite and soft itabirite & 62.65 & .89 & 88.60 & 1.25 & .044 & 6. 58 & 1.15 & .05 & n.d. & .90 \\
\hline 9 & Sheared compact hematite & 63.21 & 2.67 & 87.42 & .36 & .047 & 7.45 & .78 & .05 & n.d. & .92 \\
\hline 10 & Soft itabirite and compact hematite. & 66.60 & 1.02 & 94.11 & .14 & .022 & 3.25 & $.4 E$ & .10 & n.d. & .76 \\
\hline \multicolumn{12}{|c|}{ Drift 2} \\
\hline 11 & Canga and rolado & 67.59 & 9.10 & 86.54 & .20 & .079 & 2.15 & .70 & .10 & .05 & .85 \\
\hline 12 & 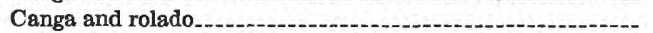 & 66.10 & 2.10 & 92.19 & .13 & .12 & 1.85 & 1.20 & .05 & .05 & 2.05 \\
\hline 13 & Soft and compact hematite & 65.25 & .40 & 92.86 & .80 & .062 & .70 & 2.45 & .25 & .15 & 1.85 \\
\hline 14 & Soft and compact hematite & 67.55 & .20 & 9637 & .60 & .033 & .51 & .75 & .15 & .10 & .95 \\
\hline 15 & Soft hematite & 68.40 & .77 & 96.95 & .30 & .025 & .45 & .55 & .05 & .05 & .65 \\
\hline 16 & Soft hematite, compact hematite, and soft itabirite & 67.75 & .95 & 95.82 & .25 & .029 & .46 & 1.10 & .05 & .05 & 1.05 \\
\hline 17 & Soft hematite, compact hematite, and soft itabirite & 67.35 & .90 & 95.31 & .16 & .034 & 1.16 & 1.10 & .05 & .10 & .75 \\
\hline 18 & Soft hematite, compact hematite, and soft itabirite............... & 66.95 & .30 & 95.41 & .30 & .025 & 1.25 & 1.15 & .05 & .10 & 1.20 \\
\hline 19 & Sheared compact hematite & 67.15 & .55 & 95.41 & .48 & .033 & .94 & .96 & .05 & .10 & .85 \\
\hline 20 & Compact hematite & 66.10 & 3.65 & 90.46 & .50 & .038 & 1.95 & 1.44 & .05 & .10 & 1.45 \\
\hline 21 & Compact hematite & 66.30 & 7.03 & 86.99 & .54 & .039 & 1.92 & 1.74 & .05 & .10 & .87 \\
\hline 22 & Compact hematite and gangue quartz & 65.15 & 6.15 & 86.34 & .25 & .54 & 5.00 & .65 & .10 & .10 & 1.05 \\
\hline 23 & Soft itabirite & 64.64 & 2.85 & 89.27 & 1.44 & .074 & 1.85 & 1.18 & .85 & .30 & 1.22 \\
\hline 24 & Sheared compact hematite, soft hematite, and hard itabirite & 65.49 & .76 & 92.80 & 1.95 & .056 & 2.10 & .52 & .05 & n.d. & .92 \\
\hline 25 & Sheared compact hematite, soft hematite, and hard itabirite & 63.36 & 2.17 & 88.19 & .31 & .038 & 7.40 & .05 & .10 & n.d. & 1.02 \\
\hline 26 & Soft itabirite and compact hematite & 51.18 & 2.03 & 70.93 & .29 & .037 & 24.24 & 1.00 & .05 & n.d. & 1.11 \\
\hline 27 & Soft itabirite and compact hematite & 48. 77 & 1.40 & 68.18 & .23 & .043 & 27.10 & .81 & .05 & n.d. & 1.22 \\
\hline 28 & Soft itabirite with small quartz lenses. & 49.00 & .51 & 69.50 & .43 & .054 & 27.00 & 1. 13 & .05 & n.d. & 1.00 \\
\hline 29 & Compact and soft hematite & 63.59 & 1.02 & 89.50 & .09 & .13 & 3.61 & 2.72 & .05 & n.d. & 1.92 \\
\hline
\end{tabular}

square meters and a height of 100 meters. Exposures in the drifts indicate that, at drift level, compact hematite covers 40 percent of the ore area, or 64,000 square meters; soft hematite covers 50 percent of the area, or 80,000 square meters; and soft itabirite covers 10 percent, or 16,000 square meters. The same ratios were used in calculating the volumes of these ores as fractions of a 100-meter high cone. Indicated reserves calculated in this manner are: Compact hematite, 9.5 million tons; soft hematite, 11 million tons; and soft itabirite, 1.6 million tons.

Indicated reserves of alluvial, and of canga and rolado ores are calculated on a basis of area and of a depth of 1 meter as shown in test pits. These total: alluvial, 150,000 tons; and canga and rolado, 420,000 tons.

Inferred reserves of compact hematite, soft hematite, and soft itabirite are projected at the rate of 290,000 tons, 320,000 tons, and 48,000 tons per meter depth, respectively. Projected to a depth of 50 meters the reserves total: compact hematite, 14 million tons; soft hematite, 16 million tons; and soft itabirite, 2.4 million tons. As these ores occur near the base of the Cauê Itabirite in the trough of a longitudinal syncline, the ores probably do not extend much more than $\mathbf{5 0}$ meters below the exploration drifts.

\section{SERRADÃo}

The Serradão deposit is a rolado and canga pediment about 300 meters wide extending for 2.5 kilometers south of the Corrego do Feijao ore body (pl. 1, N. 8,000, E. 12,200). The deposit is held by two owners: Companhia de Mineração Ferro e Carvão S.A., which owns the larger, eastern part, and Minas do Paraopeba S.A., which holds the smaller, western part. Mining operations on the east side of the deposit are 8 kilometers from the Alberto Flôres loading station on the same road spur which extends to the Corrego do Feijão ore body.

The deposit consists of a canga layer $1 / 2-2$ meters thick overlying a rolado layer $1 / 2-3$ meters thick. The canga is exposed at the surface at the upper (north) end of the pediment but is covered by as much as 2 meters of soil at its lower (south) end. The rolado overlies saprolite formed by the weathering of Souza Noschese Gneiss. Canga and rolado each cover 750,000 square meters. Averages of rolado and canga analyses from 80 test pits in the deposits indicate that the rolado contains 69.06 percent iron and the canga contains 60.90 percent iron (table 11, samples 12, 27). The rolado ore contains mixed sizes of compact hematite and itabirite fragments. Itabirite and hematite fragments less than half an inch in diameter, which make up 30 percent of the material mined, are discarded, and 2 tons of ore are recovered for each cubic meter mined.

The Serradão deposit has been mined along a 300meter length on its east side and has produced 236,000 
GEOLOGY, IRON DEPOSITS OF WESTERN SERRA DO CURRAL, MINAS GERAIS, BRAZIL

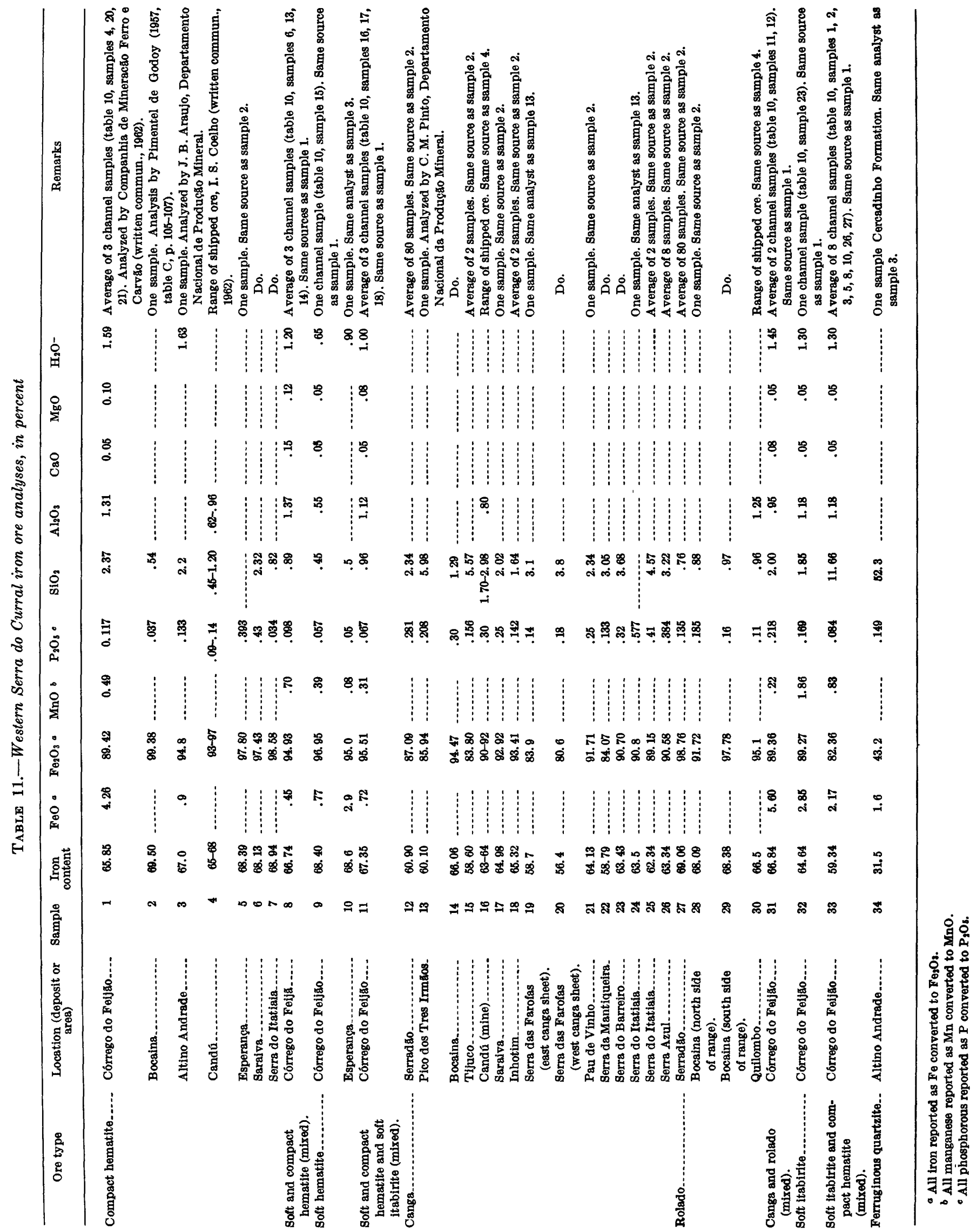


tons of lump ore $(1 / 2-8$ inches in diameter), of which all but 15,000 tons was exported. With the exception of 100 tons of ore produced in 1941, all production was between 1953 and 1961. In January 1962 the mine was inactive because the miners had been shifted to the preliminary exploratory operations at Córrego do Feijão. Total reserves are 1,500,000 tons of rolado and $2,200,000$ tons of canga.

\section{PICO DOS TRES IRMÃos}

The canga included in this section covers 400,000 square meters in three areas between Pico dos Tres Irmãos and the east boundary of the Brumadinho area near the crest of the Serra do Curral (pl. 1). The largest of these areas (N. 9,400, E. 12,000) lies chiefly on the steep southeast slope of Pico dos Tres Irmãos from where it extends to the north and west sides of the Corrego do Feijão ore body and the north end of the Serradão pediment. The other two areas are at $\mathrm{N}$. 10,000 , E. 12,800 and N. 9,600, E. 11,700. At many places, the canga is not fully exposed, but, on the basis of a few observations, it is estimated to average 2 meters in thickness. A sample from the large canga sheet contained 60.10 percent iron (table 11, sample 13). Indicated reserves are $2,400,000$ tons.

\section{LARANJEIRAS}

The Laranjeiras deposit is a canga and rolado pediment (pl. 1, N. 8,400, E. 10,400). This unexplored deposit is owned by the heirs of Olimpio Menezes de Aguir. No road to the deposit exists.

The deposit, like the Serradão deposit, consists of a canga layer about 1 meter thick overlying a rolado layer about 1 meter thick. The canga is partly exposed and partly covered by soil; the rolado overlies saprolite developed from Souza Noschese Gneiss. The pediment has an irregular shape and covers about 40,000 square meters. The deposit was not sampled, but both canga and rolado are estimated to contain about 55 percent iron. Indicated reserves are 120,000 tons of canga and 100,000 tons of rolado.

\section{BOCAINA}

The Bocaina deposits, which consist of high-grade compact and soft hematite, canga, and rolado ores, straddle the Serra do Curral 2.5 kilometers north of the village of Tijuco (pl. 1, N. 10,000 E. 9,200; pl. 4). The larger, northern part of the deposits is owned by Mineral do Brasil, Ltda., and the smaller, southern part is owned by Minas do Paraopeba, S.A. Ore from the area is transported by road to the loading station at Sarzedo on the Central do Brasil railroad.

The Bocaina deposits cover half a square kilometer, extending for 1 kilometer in an east-west direction along the crest of the Serra do Curral and half a kilometer in a north-south direction from 100 meters north to 400 meters south of the range. The area is mostly covered by canga and rolado and has scattered itabirite outcrops. Compact and soft hematite crop out at the range crest and on the south side of the range in the west, and a cluster of small soft hematite outcrops occur in the southeastern part of the area.

The compact and soft hematite are in the Cauê Itabirite, which has a general east-west trend and a steep dip to the north. The western deposits are in the middle and upper parts of the formation, and the southeastern deposits are in the middle of the formation. A small cross-range anticline occurs near the west limit of hematite outcrops but does not appear to have influenced the sites of hematite deposition.

Four varieties of ore occur in the area: compact hematite, soft hematite, rolado, and canga. The principal hematite body is a tabular mass 200 meters long and 10 meters wide and is exposed through a vertical thickness of 60 meters. The body strikes N. $20^{\circ} \mathrm{W}$. at an angle of $60^{\circ}$ to the strike of the itabirite bedding $\left(\mathrm{N} .80^{\circ} \mathrm{W}\right.$.), which is preserved in the hematite. An analysis of the hematite showed 69.50 percent iron (table 11, sample 2). The hematite body is surrounded by soft itabirite and because of its narrow shape cannot be mined at depth until the surrounding itabirite can be removed profitably.

Soft hematite occurs at two places: near the compact hematite and in the southeastern part of the area. Soft hematite near the compact hematite also occurs in soft itabirite, and only the upper few meters is presently minable. The soft hematite in the southeastern part of the area comprises numerous small outcrops surrounded by colluvium. They may all be protrusions of a larger body of soft hematite a meter or two below the surface. The soft hematite was not sampled but is estimated to contain more than 66 percent iron.

The canga and rolado, covering most of the area to a depth of 1.5 meters, are mostly high-grade ores containing abundant small fragments of compact hematite. The fine fragments, those less than a quarter of an inch in diameter, make up 50 percent of the rolado deposits and are discarded in mining. Analysis of a canga sample yielded 66.06 percent iron (table 11, sample 14). A rolado sample on the north flank of the range contained 68.09 percent iron, and a rolado sample from the south flank contained 68.38 percent iron (table 11, samples 28, 29).

Mine workings include several opencuts and an area of mined rolado. In the past, most mined ore has been rolado ore on the north side of the range. Cobble- and large pebble-sized pieces of compact hematite are removed with a pitchfork. The remaining pebblesized fragments are thrown against a screen. The larger pebble-sized pieces are then removed by hand 
shovel, and pieces less than a quarter of an inch in diameter are left behind. Perhaps as much as 50,000 tons of finesized compact hematite covers the mined area and could be recovered in the future.

Most ore being mined in 1958 was canga in a group of connected cuts, totaling about 200 meters in length, in the central part of the area. Canga has also been mined with a minor amount of compact and soft hematite from an 80-meter-long cut under the north side of the range crest in the western part of the deposit area. Bocaina has produced about 100,000 tons of ore, almost all of which has been canga and rolado. The area has been producing about 1,000 tons of ore per month since 1952 .

Reserves of all types total 2,100,000 tons and include 900,000 tons of indicated ores and 1,200,000 tons of inferred ores. The indicated ores comprise 600,000 tons of canga and 300,000 tons of rolado. Inferred ores include 550,000 tons of compact hematite and 700,000 tons of soft hematite, calculated at a rate of 11,000 and 14,000 tons per meter depth, respectively, and projected to a depth of 50 meters.

A departure was made from the procedure used in other Serra do Curral deposits in classifying and calculating the Bocaina hematite reserves. As it will be a few years before the soft hematite surrounding the principal compact hematite body is saleable, the compact hematite even though exposed in three dimensions is classified as inferred rather than indicated ore. No allowance has been made for the extension of this body below its lowest outcrop. Experience at the Candú mine area has shown that where a number of narrow hematite bodies occur in a given area, the same proportion of hematite ore to itabirite as occurs near the surface may be expected at depth even though individual bodies thin out. However, at Bocaina where only one such body is known, such a projection does not seem warranted. Similarly, soft hematite ore does not occur in large enough bodies to permit mining without removing the adjacent soft itabirite. Thus the soft hematite is also classed as inferred ore.

\section{TIJUCO CANGA DEPOSIT}

The Tijuco canga deposit, the largest canga and rolado pediment in the western Serra do Curral region, covers $1 \frac{1}{4}$ square kilometers (pl. 1, N. 8,000, E. 9,700). Although no road extends onto the deposit, the village of Tijuco, at the west side of the deposit, is 7 kilometers from the Alberto Flôres loading station on the Central do Brasil railroad.

The canga occurs in a layer averaging $1 \frac{1}{2}$ meters thick and overlies a layer of rolado averaging 1 meter thick. The canga is almost entirely covered by soil from a few centimeters to 2 meters thick, but both the canga and rolado are exposed in numerous places along the margin of the deposit. The rolado overlies saprolite formed by weathering of Souza Noschese Gneiss.

The canga and rolado contain abundant itabirite fragments and do not have as high an iron content as some other canga and rolado deposits. However, the Tijuco deposit has not been thoroughly explored, and sampling might indicate certain areas to be more favorable than others. Two samples of canga averaged 58.60 percent iron (table 11 , sample 15). The rolado is estimated to contain 55 percent iron. Indicated reserves are $8,100,000$ tons of which 5,600,000 tons are canga and 2,500,000 tons are rolado.

\section{TIJUCO ROLADO}

The Tijuco rolado is a high-grade compact hematite rolado deposit covering $1 \frac{1 / 4}{4}$ square kilometers, 1 kilometer north of the village of Tijuco (pl. 1, fig. 11). The principal part of the deposit, known by the names Quilombo, Quilombo Doce, and Tijuco, is mined by Icominas, S. A. The eastern part of the deposit, known as Tres Irmãos, is mined by Minas do Paraopeba, S. A. The southwest corner of the deposit, known as the Socomine concession, has been completely mined by the company of the same name. The deposit is 8 kilometers by an all-weather road from the Alberto Flôres loading station on the Central do Brasil railroad.

The Tijuco rolado consists of compact hematite fragments ranging in size from small pebbles to boulders 2 meters and more in diameter, mixed with red earth; the mixture overlies saprolite weathered from Souza Noschese Gneiss (fig. 12). The deposit undoubtedly resulted from erosion of a compact hematite body in the Bocaina area when the Serra do Curral was somewhat higher than it is today and before drainage channels were so well developed. The northern part of the Tijuco deposit is less than a kilometer downslope from compact hematite in the Bocaina area and is 150 meters below the present range crest. The deposit is also connected with rolado in the Bocaina area by a narrow rolado band 35 meters wide, but could not have reached its position since the development of the steep narrow valley which almost transects the rodado connection with the Bocaina area.

This rolado is the source of a second generation of rolado. Entrenching streams on the north, west, and south sides of the deposit steepened slopes, causing rolado to slump over the new valley sides. The younger rolado thus formed occurs in a crescent-shaped area around the older rolado.

Both the younger and the older rolados range irregularly in thickness, from $50 \mathrm{~cm}$ to $2 \frac{1}{2}$ meters and from $50 \mathrm{~cm}$ to 6 meters, respectively. The unmined part of the 


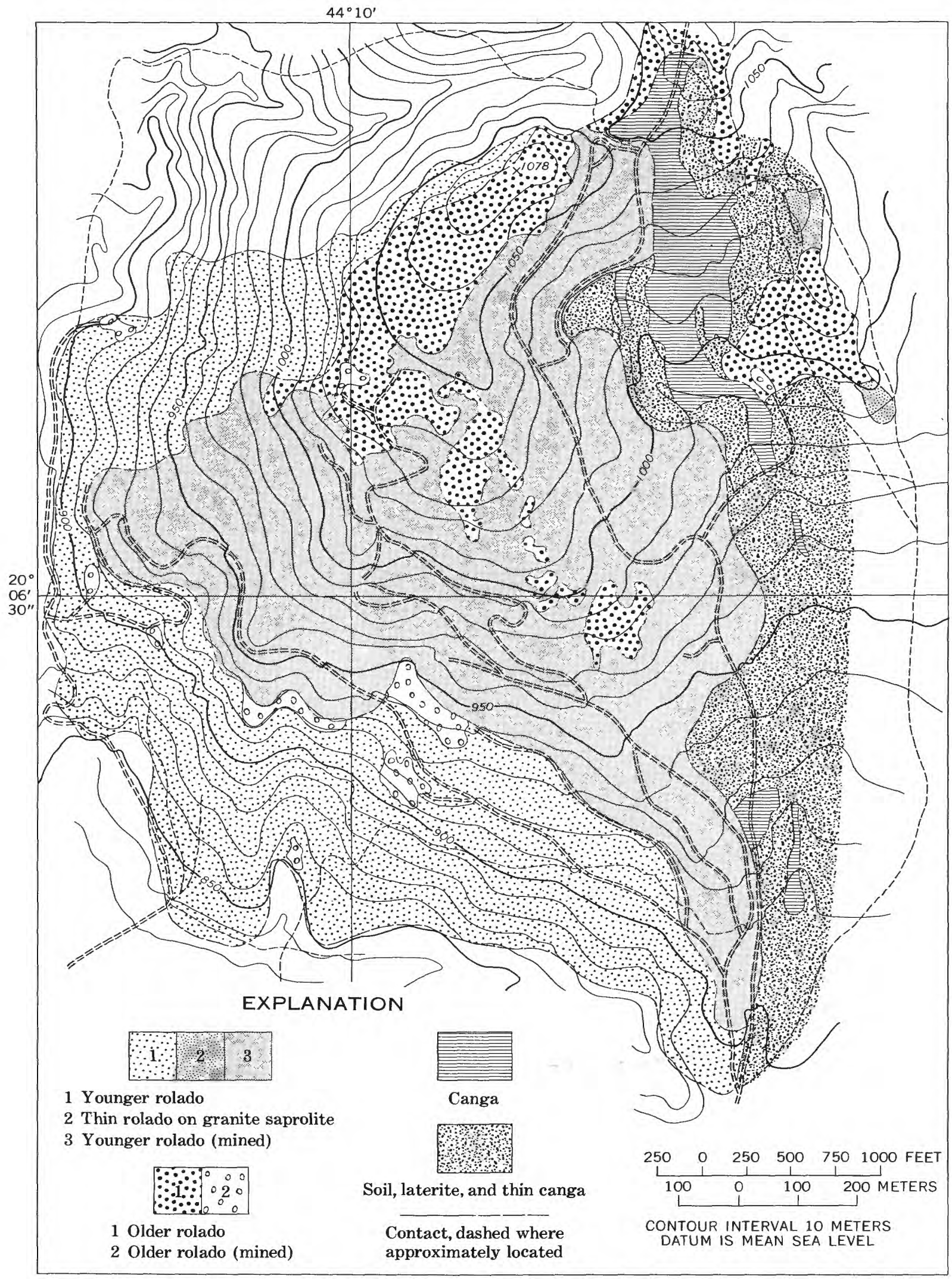




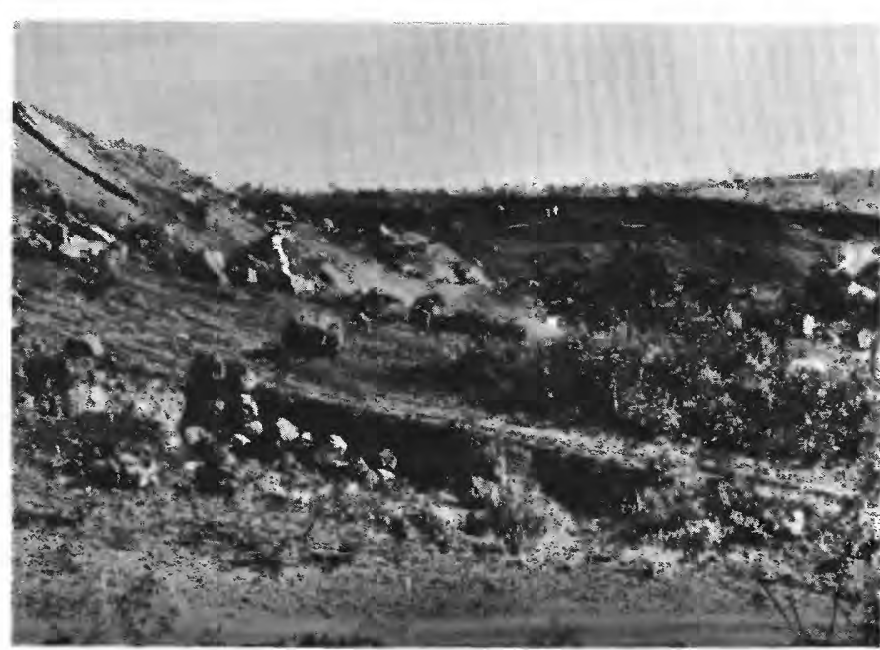

FiguRe 12.-Tijuco rolado deposit.

older rolado has an average thickness of 4 meters. The size distribution of hematite fragments also varies irregularly. The ore is mined from open faces extending from the surface to the top of the granitic saprolite. Volumes of several cubic meters believed to contain only fines are left unmined. So much fine material is discarded that the mining companies use a specificgravity factor of 2 in calculating reserves. Ore on the Quilombo property is screened manually to separate ore more than half an inch in diameter for export. The fine fraction, a quarter to half an inch in diameter, is stocked on the property (I. S. Coelho, written commun., 1962). Almost all ore produced from Tijuco contains more than 66 percent iron. An average analysis of ore produced from the Quilombo property contains 66.5 percent iron (table 11, sample 30).

Production from the Tijuco rolado deposit through 1961 totaled about $1,500,000$ tons, most of which was exported. Although small-scale mining commenced in the early 1940's, little ore was mined until 1949. According to I. S. Coelho (written commun., 1962), the Quilombo property produced 910,000 tons of ore from 1949 through $1961,56,000$ tons of which was produced in the latter year.

Indicated reserves are $1,600,000$ tons, calculated on a basis of unmined older rolado covering an area of 200,000 square meters to an average depth of 4 meters. Younger rolado, much of which is near the minimum minable thickness of $50 \mathrm{~cm}$ and possibly recoverable fine hematite discarded during earlier mining are not included in the calculations.

\section{SERRA FÊCHO DO FUNH}

Three canga sheets covering 160,000 square meters on the crest and north side of the Fêcho do Funil section of the Serra do Curral lie 1 kilometer east of the Rio Paraopeba (pl. 1). The cangas are about 2 meters thick. Although the larger canga layer has been explored, the writer was unable to contact the property owner, Sr. Manoel Campos, for sample analyses. The canga is estimated to contain 60 percent iron; indicated reserves are 960,000 tons.

\section{ALTINO ANDRADE}

The Altino Andrade deposit is a very small highgrade compact hematite deposit on the west bank of the Rio Paraopeba and is transected by the Central do Brasil railroad (pl. 1). The property is owned by Sr. Altino Andrade.

The hematite occurs in an itabirite lens at the top of the Gandarela Formation. The hematite crops out over a few tens of square meters, an areal extent of probably not more than 200 square meters, and is well exposed only in a railroad cut. A sample from the railroad cut contained 67.0 percent iron (table 11 , sample 3).

The lens containing the hematite body is offset about 15 meters along a north-trending normal fault passing 10 meters west of the hematite body, and fractured basal quartzite of the Cercadinho Formation is exposed in fault contact with the itabirite lens. The fault zone, about 1 meter wide, contains breccia fragments of itabirite and ferruginous quartzite cemented by siliceous compact hematite. Fractures in adjacent ferruginous quartzite of the Cercadinho Formation are also filled with siliceous hematite. Two or three hundred tons of ferruginous quartzite were mined during exploration for extension of the hematite body. A sample of ferruginous quartzite contained 31.5 percent iron (table 11, sample 34).

\section{SOUZA NOSCHESE}

The three deposits included in this section are a mined rolado deposit and two small canga sheets near the crest of the Serra do Curral west of the Rio Paraopeba and east of the Candú area (pl. 1). The rolado deposit was mined by Sr. I. R. Souza Noschese in the 1930's during early mining operations in the Candú area. The rolado deposit is accessible from the Esperança mine by an abandoned road half a kilometer long. The deposit is 3 kilometers by road from the Souza Noschese loading station on the Central do Brasil railroad.

The two canga layers extend from the range crest a few tens of meters down the north slope, cover 40,000 square meters, and are 2 meters thick. The canga is estimated to contain 55 percent iron. Indicated reserves are 240,000 tons. The mined rolado deposit extends south from the range crest and covers 100,000 square meters. The area is littered with discarded fine hematite fragments which may be recoverable when fine ores are acceptable to national smelters. 


\section{CANDÚ AREA}

The Candú area contains high-grade compact and soft hematite, rolado, and canga ores extending for more than half a kilometer near the crest of the Serra do Curral; the area contains rolado ore south of the range. The area is $1 \frac{1}{2}$ kilometers west of the Rio Paraopeba (pls. 1, 5).

The primary ore body, mostly compact hematite, is opened by three mines, the Saraiva, Candú, and Esperança; these mines are operated by Minas de Ferro, S.A., Mineração Geral do Brasil, and Empresa de Mineração Esperança, Ltda., respectively. The principal rolado deposits are worked in the Inhotim mine by Minas do Paraopeba, S.A. Ore from the Saraiva mine is trucked 3 kilometers to the loading station at Fêcho do Funil, ore from the Candú and Esperança mines is trucked 2 kilometers to the loading station at Souza Noschese; and ore from the Inhotim mine is trucked 3 kilometers to the loading station at Inhotim.

The extent of the primary ore is not completely known but is probably limited to an 80,000 -squaremeter area. The ore is in a curved body about 600 meters long that averages 130 meters wide and is exposed through a height of 80 meters.

The ore body largely consists of compact hematite that has selectively replaced itabirite, although numerous veins of compact hematite occur along joints and fractures in both replaced and unreplaced itabirite. The ore, although a bedding replacement in detail, has a gross transgressive relation with the itabirite. To the east, in the Esperança mine and eastern part of the Candú mine, the replaced beds are at and near the base of the Cauê Itabirite (fig. 13). Replaced beds are higher in this formation to the west, and in the Saraiva mine, replaced beds are at the top of the Cauê

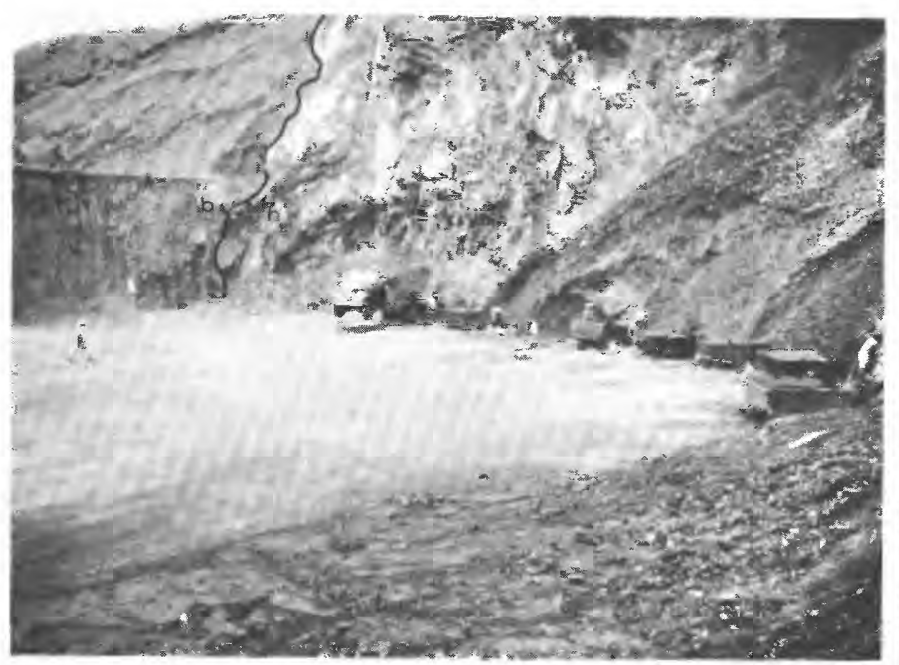

Figure 13.-Contact of the Batatal Formation (b) and compact hematite (h) replacement of the Caue Itabirite at the Esperança mine.
Itabirite and possibly the lower part of the Gandarela Formation.

The individual replacement bodies are tabular lenses which range from pebble size to deposits 210 meters long and 20 meters wide that are exposed to depths of 30 meters. Interbedded itabirite and ferruginous phyllite must be removed in mining, but this is easily done as the itabirite is weathered to soft itabirite and partially softened itabirite. Nevertheless, removal from around the hematite is an economic problem in the Esperança mine, where only a third of the mined material is ore.

The primary ore body is structurally localized on a cross-range syncline, open to the north, whose shape resembles the lip of a pitcher. The Caue Itabirite trends N. $60^{\circ} \mathrm{E}$. with the general trend of the Serra do Curral and dips steeply to the northeast. In the area near the Saraiva mine the formation flexes abruptly to the southeast and dips moderately to the northeast. Farther northeast, in the Candú mine, the southern, lower part of the Cauê Itabirite is flexed into a horizontal position to form the pitcher lip, and in this lip occur gentle longitudinal folds parallel to the strike of the Serra do Curral. The corresponding northern, upper part of the Caue Itabirite in the northern part of the Candu mine dips gently to moderately north to form the back of the pitcher lip. At the east side of the Candú mine the Caue Itabirite flexes abruptly again, and in the Esperança mine area it returns to the general N. $60^{\circ} \mathrm{E}$. strike of the range and has steep and overturned dips.

Three rolado deposits of compact hematite, one on the range crest and two on the south flank, cover a total area of 150,000 square meters. The deposit on the range crest overlies the Itabira Group and covers 75,000 square meters. About 50,000 square meters of this area is unmined, and the deposit is 1 meter thick. The uppermost flank deposit extends from the lower part of the Cauê Itabirite downslope and across the Caraça Group onto Souza Noschese Gneiss. It covers 50,000 square meters, 20,000 of which is mined out. This deposit has a thickness ranging between $25 \mathrm{~cm}$ and 3 meters. The lowermost deposit is entirely on Souza Noschese Gneiss. This rolado unit covers 25,000 square meters, 10,000 of which is mined out and has a thickness ranging between $50 \mathrm{~cm}$ and 2 meters. The latter deposit is shown on plate 1 , but only its north end appears on plate 5 .

Canga extends southwestward for about 1,300 meters west from the Candú area along the range crest. Near the Saraiva and Candú mines this material has a higher iron content and contains more compact hematite fragments than toward the southwest end. The change in tenor of iron occurs along a line projected S. $35^{\circ} \mathrm{E}$. from the south corner of the mine building (shown at the 
west side of the Saraiva mine near the west margin of pl. 5). The line of change may approximate the west limit of the underlying compact hematite ore body. Canga within the area occurs in a 2-meter-thick layer covering 12,000 square meters. Most of the layer overlies the Cauê Itabirite and compact hematite in the ore body. However, a thin strip isolated from the main mass of canga by mining operations extends down the north slope, where it overlies the Batatal Formation.

Four types of ore mined in the Candú area are compact hematite, soft hematite, rolado, and canga. Compact hematite occurs in two principal varieties: one is bluish-gray and has alternating laminae of dense and very fine grained hematite; the other is bluish-gray dense hematite characterized by conchoidal fracture. The laminated hematite is a replacement of itabirite (fig. 8). Individual laminae were traced in outcrop for several meters into less completely replaced itabirite where the very fine-grained laminae contain visible quartz (fig. $9 \mathrm{C}$ ). Some laminated hematite exists in which the quartz in the original itabirite was removed but only partially replaced by hematite so that the dense laminae alternate with laminae which are partly void (figs. $9 A, B$ ). The variety of dense hematite that has a conchoidal fracture occurs in cross-cutting veins (fig. $9 \mathrm{C}$ ) and has replaced itabirite in which the original laminae are not discernible. Compact hematite mined from the Candú mine contains $65-68$ percent iron (table 11, sample 4). Analyses of compact hematite from the Esperança and Saraiva mines contain, respectively, 68.39 percent and 68.13 percent iron (table 11 , samples 5,6 ).

Two varieties of soft hematite resulted from weathering of laminated hematite and laminated hematite with voids. Dense hematite does not weather readily, and no soft hematite derived from this ore was found. Soft hematite derived from laminated hematite occurs sparingly near the surface but not in bodies large enough to show at the map scale of $1: 2,500$; it occurs only in small pods in the bottoms of the mine pits. Soft hematite derived from laminated hematite with voids occurs from the surface to a depth of 35 meters on the north side of the Esperança mine. This material is black and is harder than most soft hematite in the Quadrilátero Ferrífero, and it is even harder at depth than near the surface. The color is imparted by black powdery hematite which coats the numerous vugs in the ore. The black powdery hematite looks like manganese oxide but gives a red streak. The hardness results from the presence of many veinlets and laminae of dense hematite, both resistant to weathering. A sample of this soft hematite contained 68.6 percent iron (table 11, sample 10).
Two varieties of canga ore, structure canga and canga rica, resulted from weathering of itabirite and compact hematite. Structure canga, prominent along the divide between the Candú and Saraiva mines, occurs mixed with a small amount of canga rica. Although the original hematite-rich layers in the structure canga are almost completely replaced by limonite, the bedding is well preserved. The gradation of structure canga into enriched itabirite, which, in turn, grades in to soft itabirite, is well exposed in the upper part of the Candú mine. The range in composition of canga mined in the Candú mine is 63-64 percent iron (table 11, sample 16). A sample of canga from the Saraiva mine contained 64.98 percent iron (table 11, sample 17).

Canga rica containing cobbles and pebbles of compact hematite cemented by small amounts of limonite occurs on the upper part of the Inhotim property. Two samples of this ore contained 64.47 and 66.15 percent iron (table 11, sample 18).

The rolado ores contain high-grade compact hematite detritus of various sizes mixed with itabirite fragments and earth. Ore at the range crest contains a high percentage of fines that are less than a quarter of an inch in diameter and much earthy material. The upslope rolado ore contains soft itabirite fragments that weathered from hard itabirite after the accumulation of the deposit. This ore is also poorly sorted; the coarser detritus is concentrated toward the surface and east side of the deposit. The downslope rolado ore contains many cobbles and small boulders of compact hematite, most of which have been mined. According to Rolen van Nordheim (written commun., 1958), the rolado ores mined on the south slope of the range on the Inhotim property contained more than 68.5 percent iron.

Candú area mine workings consist of three main pits, five short exploration drifts, and many opencuts, test pits, and stripped areas. Ore is mined in the Candú pit on five levels through a vertical range of 75 meters, from 970 to 1,045 meters; ore is mined in the Saraiva pit on three levels through a vertical range of 45 meters, from 1,000 to 1,045 meters; and ore is mined in the Esperança pit on one level through a vertical range of 40 meters, from 955 to 995 meters. Altogether the three pits expose the primary ore body through a vertical range of 90 meters.

Four drifts on the Inhotim property, two of which are shown on plate 5 and two of which are west of the area shown on plate 5 , were started near the contact of the Cauê Itabirite and the Batatal Formation. The drifts were driven to the north in exploration for a westerly extension of the primary ore body. The easterm drift is the longest, 35 meters, and is entirely in itabirite. 
A drift at the Saraiva mine started near the base of the Cercadinho Formation and was driven south into phyllite of the Gandarela Formation. The drift was abandoned before it reached the ore body and is now covered by a mine dump.

Opencuts were made to mine canga and thicker parts of rolado deposits and to explore for ore extensions. Numerous shallow pits were excavated, principally to test the thickness of rolado deposits, but also to explore for ore extensions. Most stripping has been in connection with the mining of rolado deposits.

Estimated production from the Candú area since mining started in the Saraiva mine in the middle thirties is 2,250,000 tons. Of this amount, 2,000,000 tons is compact hematite, 150,000 tons is rolado, and 100,000 tons is canga ores. About 95 percent of the compact hematite and rolado ores was exported, and the other 5 percent and all of the canga ores were shipped to domestic smelters.

Most production has come from the Candú mine, where $1,300,000$ tons of compact hematite was mined between 1945 and 1961 , and 60,000 tons of canga was mined between 1945 and 1948 (I. S. Coelho, written commun., 1962). Production records for the other mines are incomplete. The present annual production for all ores from all mines is estimated as 80,000 tons, of which 65 percent is from the Candú mine.

Total ore reserves are 3,900,000 tons, of which indicated reserves are 1,400,000 tons and inferred reserves are $2,500,000$ tons. Indicated reserves include $1,100,000$ tons of compact hematite, 68,000 tons of soft hematite, 72,000 tons of canga, and 173,000 tons of rolado ores; the rolado ores occur in three deposits of $75,000,60,000$, and 38,000 tons. Inferred reserves include $2,200,000$ tons of compact hematite and 260,000 tons of soft hematite ores.

Indicated compact hematite reserves were calculated by determining the volume of each hematite lens from its exposed surface area and vertical range. These bodies have a total surface area of 10,000 square meters and an average vertical range of 25 meters. Soft hematite, occurring in quantity only on the side of one mine pit, covers an area of 17,000 square meters, has a height of 40 meters, and was calculated as the volume of a cone because of the shape of the exposure. Rolado and canga reserves were calculated on the basis of unmined areas and average thickness; the rolado reserves were also based on a variable recovery factor dependent on the ratio of fragment sizes larger or smaller than a quarter of an inch in diameter.

Inferred reserves of compact and soft hematite are calculated on the basis of exposed surface area per meter depth and occur at the rate of 40,000 and 5,200 tons per meter, respectively. Excluded from the calcu- lations are small bodies of compact hematite in the flat-lying beds in the southern part of the Candú pit. These beds are a few meters above the Batatal formation, and hematite occurring in them cannot be projected.

Two canga sheets in the Serra das Farofas section of the Serra do Curral cover 460,000 square meters along the range crest. The larger, eastern sheet exten ds 1.2 kilometers west from the Candú area (pl. 1) and, excluding the small part discussed under the Candu deposits, covers 300,000 square meters. The smaller, western sheet lies 0.2 kilometer farther west, extends for 0.7 kilometer along the range, and covers 160,000 square meters. Both cangas average 2 meters in thickness and together contain 2,800,000 tons of indicated reserves. Samples from the larger and smaller sheets contained 58.7 percent and 56.4 percent iron, respectively (table 11, samples 19, and 20).

A rolado deposit, mostly composed of canga blocks, lies on the north side of the range, north of the larger canga sheet. This deposit, not indicated on the map, only locally covered the Cercadinho Formation. The deposit was mined during the 1930's, and any records of the small production are unknown.

\section{PAU DE VINHO}

Pau de Vinho is a small canga rica deposit astride the boundary common to the Fêcho do Funil and Igarapé quadrangles (pls. 1, 2; fig. 14). The deposit is owned by Cómercio e Exploração de Minérios, Ltda., and ore is trucked 7 kilometers over an all-weather road to the Central do Brasil railroad loading station at Brumadinho.

The deposit, consisting of a canga layer 2 meters thick with local lenses of rolado a few centimeters thick at its base, covers 65,000 square meters. It extends from the range crest, where it overlies the Caue Itabirite, across the Gandarela Formation onto the Cercadinho Formation, a distance of half a kilometer. A sample of the canga contained 64.13 percent iron (table 11, sample 21).

The canga contains many pebble-sized fragments of compact hematite and itabirite. The abundance of hematite pebbles and their proximity to the range crest suggests that their source, if not completely eroded, is nearby. Canga rica commonly surrounds outcrops of compact hematite; but also at many places such as at Samambaia in the Ibirité quadrangle, compact hematite has been found completely covered by canga (Pomerene, 1964, p. 55). No compact hematite is exposed at Pau de Vinho. Perhaps when mining strips off the canga closer to the range crest a small body of compact hematite will be uncovered. 


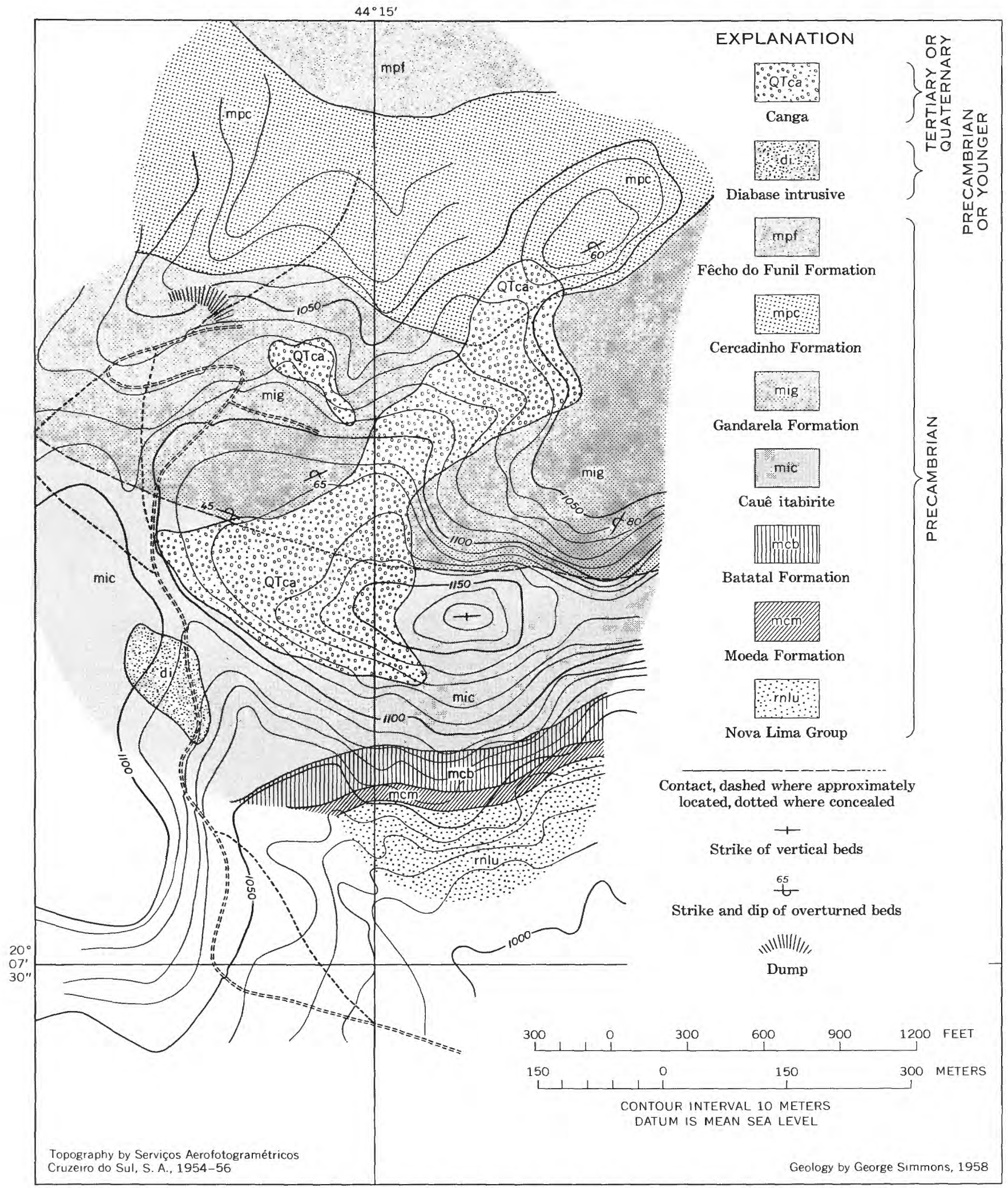

FIGURE 14.-Geologic map of the Pau de Vinho mine. 
The Pau de Vinho canga is worked in an opencut on the northeast side of the deposit, and as mining proceeds the cut is moved upslope to the south. Production through 1958 is estimated at 100,000 tons, and production during 1958 was about 1,000 tons per month. Indicated reserves are 390,000 tons.

\section{WEST END AREA}

Iron deposits in the West End area were not studied in detail, but, with one minor exception, all deposits in that area are canga, rolado, and enriched itabirite. No soft hematite and only one small lens of high-grade compact hematite was found in traversing the range crest during reconnaissance mapping.

Most of the deposits occur in long narrow bands ov erlying the Cauê Itabirite on the crest of the Serra do Curral and locally extend downslope onto other formations. Canga overlies much of the rolado, but many rolado deposits developed downslope from canga and other rolado lies on canga. The canga averages 2 meters in thickness, and the rolado averages 1 meter. Reserves in the West End area are summarized according to the section of the Serra do Curral in which they occur: Serra da Mantiqueira-Serra do Barreiro, Serra do Itatiaia, and Serra Azul.

SERRA DA MANTIQUEIRA-SERRA DO BARREIRO

The limits of the different sections of the Serra do Curral have never been defined, and the names applied to them are not standardized. For the purposes of this paper the Serra da Mantiqueira, sometimes called part of the Serra das Farofas, and the Serra do Barreiro, sometimes called Serra do Gentio, make up that part of the Serra do Curral between the pass on the west side of the Pau de Vinho mine and Garganta da Conquistinha (Conquistinha Pass) (pl. 2). This part of the Serra do Curral is about 5.5 kilometers long, and 3.5 kilometers of its length is covered by canga and rolado. Two-thirds of the deposits are in the Serra da Mantiqueira to the east, and one-third are in the Serra do Barreiro to the west. The deposits mostly overlie the Cauê Itabirite but also overlap the Cercadinho Formation to the north and the Batatal and Moeda Formations and the Nova Lima Group to the south.

The canga occurs in one sheet, covering $1,800,000$ square meters to an average depth of 2 meters. The thickness of the canga can be seen at many places along the edges of the sheet and in pits and trenches. The rolado deposits are not as well exposed as the canga, but cover about 450,000 square meters to an average depth of 1 meter. The average iron content of both canga and rolado is estimated as 58 percent. Samples of canga from the Serra da Mantiqueira (Farofas) and
Serra do Barreiro (Gentio) contained 58.79 percent and 63.43 percent iron, respectively (table 11 , samples $22,23)$.

The Serra da Mantiqueira has been explored at several places for compact hematite by trenches and pits through canga and rolado. These workings, mostly on the Tres Pontes and Fazenda Brumadinho properties belonging to Dr. Pedro Paulo Martins Guimarães and Sr. João Procopio de Rezende, respectively, penetrated enriched and soft itabirite but no hematite.

The only ore produced from this section of the Serra do Curral was a small amount of enriched itabirite from the extreme west end of the Serra do Barreiro at Garganta da Conquistinha. Judging from the size of the abandoned excavation, the author thinks that about 20,000 tons of itabirite was mined. At this place itabirite was brecciated along a normal fault, facilitating the movement of meteoric water, and enriched itabirite formed as much as 10 meters below the surface. Indicated reserves for the Serra da Mantiqueira-Serra do Barreiro section are $11,000,000$ tons of canga and 900,000 tons of rolado.

\section{SERRA DO ITATIAIA}

The Serra do Itatiaia is about 6.5 kilometers long and extends from Garganta da Conquistinha to the first topographic saddle west of Pico do Itatiaiuçu (pl. 2). The Serra do Itatiaia contains four canga sheets extending in an almost unbroken line for more than 5 kilometers along its crest, several rolado deposits, and one small lens of compact hematite.

The canga and rolado deposits mostly overlie the Cauê Itabirite. However, the east canga sheet extends down the north slope onto the Cercadinho Formation, and the three west sheets extend down the south slope onto the Caraça Group. Canga in the four sheets covers a total of $1,600,000$ square meters and has an average thickness of 2 meters. Rolado covers 200,000 square meters and has an average thickness of 1 meter. Three canga samples from the Serra do Itatiaia contained 62.7 percent iron (table 11 , samples 24,25 ). The rolado is estimated to average 57 percent iron.

A lens of compact hematite, the only compact hematite known in the Serra do Curral west of the Candú mine, crops out about 300 meters east of Pico do Itatiaiuçu. It protrudes several meters above a small rolado deposit of compact hematite and has an area of about 800 square meters. A sample of hematite from this lens contained 68.94 percent iron (table 11, sample 7).

Small quantities of canga and rolado have been mined on the south side of the two western canga layers and from the east end and north side of the east canga sheet. However, the workings are small and total pro- 
duction has probably been less than 50,000 tons. Indicated reserves are $9,600,000$ tons of canga and 400,000 tons of rolado. Inferred reserves of compact hematite calculated at 3,600 tons per meter depth and projected to a depth of 50 meters are 180,000 tons.

\section{SERRA AZUL}

The Serra Azul, westernmost section of the Serra do Curral, is 14 kilometers long. The east end of the section, a little less than 1 kilometer long, is in the southwest corner of the Igarapé quadrangle (pl. 2). The large part of the range is in the Serra Azul and Itatiaiuçu quadrangles (pl. 3). More than 11 kilometers of the crest of the Serra Azul is overlain by three long narrow canga sheets and associated rolado deposits. From east to west the three canga sheets are approximately 4, 5.5, and 2 kilometers long, respectively. A fourth canga sheet, 1.1 kilometers long and 250 meters wide, lies on the north side of the range at its east end and near the head of Córrego da Pedra Grande (pl. 2).

The canga and rolado deposits on the range crest mostly overlie the Cauê Itabirite, but both the east and middle sheets locally overlie the Cercadinho Formation, which occurs near the range crest on the north side of the range, and the Caraça Group which occurs on the south side of the crest. The middle canga layer extends as much as half a kilometer south of the range crest, covering a dip slope of overturned Cauê Itabirite. The canga sheet north of the range caps a pediment overlying the Fêcho do Funil Formation, Taboões Quartzite, and Sabará Formation. The canga deposits cover 2,300,000 square meters and have an average thickness of 2 meters. The rolado deposits have an aerial distribution of 200,000 square meters and an average thickness of 1 meter. The canga is estimated to average 62 percent iron; the rolado, 60 percent iron. Eight canga samples had an average iron content of 63.34 percent (table 11, sample 26).

Canga and rolado are mined from numerous small excavations in the Serra Azul, and enriched itabirite is mined with the canga at two places. Mining operations are concentrated along the western part of the middle canga sheet and near the graben at the east end of the middle canga sheet and west end of the east canga sheet, and it is in these two areas where enriched itabirite is mined. All the ore is shipped by truck to Itáuna and Divinopolis, small cities west of the Serra do Curral. Indicated reserves are $14,000,000$ tons of canga and 400,000 tons of rolado ores.

\section{OTHER MINERAL RESOURCES} MANGANESE

Manganese is concentrated at many places in the western Serra do Curral from the weathering of man- ganiferous dolomite in the Gandarela and Fêcho do Funil Formations. The weathering effect on dolomitic rock is well displayed in the Brumadinho area along roadcuts and railroad cuts near Fêcho do Funil (pl. 1) where unweathered blocks of high dolomite content occur in masses of "splash rock," manganiferous earth, and siltstone. At the Bocaina quarry, dolomite also occurs with black manganiferous "splash rock." Supergene enrichment occurred at the two prospects described in the following sections, but no ore was mined from either locality.

\section{MANOEL SAMPAIO PROSPECT}

A manganese prospect in the stream bottom of Córrego da Estiva, is on Fazenda Bela Vista, owned by Manoel Sampaio (pl. 1, N. 10,500, E. 11,000). The deposits occur as several small lenses, less than a meter thick, in what is probably a weathered dolomitic itabirite near the top of the Gandarela Formation. The few outcrops are surrounded by dense vegetation, and it was impossible to determine if the lenses were limited to the few exposures or were more extensive. A chemical analysis showed $\mathrm{Mn}, 41.99$ percent; $\mathrm{SiO}_{2}, 4.34$ percent; Fe, 1.11 percent; and $\mathrm{P}, 0.246$ percent (Pimentel de Godoy, 1957, p. 89).

\section{SERRA AZUL PROSPECTS}

Several manganese prospects are in the north-central part of the Itatiaiuçu quadrangle on the north side of Serra Azul. The prospects consist of opencuts in the Fêcho do Funil Formation near its contact with the Cercadinho Formation.

The manganese occurs in irregular pods as much as 1 meter thick and several meters long for a distance of several hundred meters in what appears to be the same horizon. Most of the material is low grade. A sample selected as being of the highest grade was tested and found to contain 33.2 percent manganese (C. M. Pinto, Departamento Nacional da Produção Mineral, analyst).

\section{GOLD}

Gold was mined in the early 1800 's from a small deposit on the south side of the Serra do Curral at a place known as Gruta do Itatiaiuçu (Itatiaiuçu Cave) or Gruta da Grupiara (pl. 2, N. 8,300, E. 1,000). The old workings on property belonging to Sr. Luiz de Souza Faria are excavations in soft itabirite underlying the edge of a canga sheet. The excavations consist of six rooms, 2-4 meters high, having a total length of 25 meters and extending 12 meters under the canga. According to local residents, the property has been prospected several times, but no gold has been found since the early mining days. 


\section{GNEISS}

Souza Noschese Gneiss has been quarried near Brumadinho and Souza Noschese. Most of the quarries are near the Central do Brasil railroad and supplied riprap for the roadbed. None of these quarries has been operative for many years.

\section{CLAY}

Several small clay pits are in the area in weathered Souza Noschese Gneiss. All the clays are of low refractory quality; the clay is used to make bricks and roof tiles for local construction.

\section{LITERATURE CITED}

Barbosa, Octávio, 1934, Resumo da geologia do Estado de Minas Geraes: Minas Geraes Dept. Serv. Geog. Geol., Bol. 3, 40 p.

—_ 1954, Evolution du géosynclinal Espinhaço: Internat. Geol. Cong., 19th, Algiers 1952, Comptes rendus, sec. 13, pt. 2, facsim. 14, p. 17-36.

Departamento Nacional da Produção Mineral, 1959, Esbôço Geológico do Quadrilátero Ferrífero de Minas Gerais, Brasil: Brazil Dept. Nac. Produção Mineral, Pub. Espec. 1, 120 p., 1 map. [Portuguese and English.]

Derby, O. A., 1881, Contribuição para o estudo da geologia do valle do Rio São Francisco: Archivos do Museu Nac. do Rio de Janeiro, v. 4, p. 87-119.

- 1896, Decomposition of rocks in Brazil: Jour. Geology, v. 4 , p. $529-540$.

1901, On the mode of occurrence of topaz near Ouro Preto, Brazil: Am. Jour. Sci., 4th ser., v. 11, p. 25-34.

—_ 1906, The Serra do Espinhaço: Jour. Geology, v. 14, no. 5 , p. $374-401$.

- 1910, The iron ores of Brazil; Internat. Geol. Cong., $11 \mathrm{th}$, Stockholm 1910, Iron ore resources of the world, v. 2, p. $813-822$.

Dorr, J. V. N., 2d, and Barbosa, A. L. M., 1963, Geology and ore deposits of the Itabira district, Minas Gerais, Brazil: U.S. Geol. Survey Prof. Paper 341-C, 110 p.

Dorr, J. V. N., 2d, Gair, J. E., Pomerene, J. B., and Rynearson, G. A., 1957, Revisão da estratigrafia pre-Cambriana do Quadrilátero Ferrífero: Brazil Div. Fomento Produção Mineral Avulso 81, 31 p.

Eschwege, W. L. von, 1833, Pluto Brasiliensis: Berlin, G. Reimer, 622 p.

Freyberg, Bruno von, 1932, Ergebnisse geologischer Forschungen in Minas Geraes (Brasilien): Neues Jahrb. Mineralogie, Geologie, Palaontologie, Sonderband 2, $403 \mathrm{p}$.

— 1934, Die Bodenschätze des Staates Minas Geraes (Brasilien): Stuttgart, E. Schweizerbartsche Verlagsbuch, $453 \mathrm{p}$.

Gair, J. E. 1958, The Sabará Formation: Soc. Brasileira Geologia Bol. 7, no. 2, p. 68-69.

1962, Geology and ore deposits of the Nova Lima and Rio Acima quadrangles, Minas Gerais, Brazil: U.S. Geol. Survey Prof. Paper 341-A, 67 p.

Gorceix, Henri, 1881, Estudo geologico das jazidas de topazios da provincia de Minas Gerais: Ouro Preto, Escolo de Minas, Annaes, v. 1, p. 13-34.

__ 1883, Estudo chimico e mineralogico das rochas dos arredores de Ouro Preto: Ouro Preto, Escola de Minas, Annaes, v. 2, p. 5-22.
1884, Bacias terciarias d'agua doce nos arredores de Ouro Preto, Minas Gerais: Ouro Preto, Escola de Minas, Annaes, v. 3, p. 95-114.

Guild, P. W., 1957, Geology and mineral resources of the Congonhas district, Minas Gerais, Brazil: U.S. Geol. Survey Prof. Paper 290, 90 p.

Guimarães, Djalma, 1931, Contribuição a geologia do Estado de Minas Geraes: Brazil, Serviço Geol. Mineralóg., Bol. 55, $36 \mathrm{p}$.

- 1935, Contribuição ao estudo da origem dos depósitos d $\lrcorner$ minério de ferro e manganês do Centro de Minas Geraes: Brazil Serviço Fomento Produção Mineral, Bol. 8, 70 p. - 1937, Contribuição à metallogenese do massiço Brasileiro: Brazil Serviço Fornento Produção Mineral, Bol. 16, 86 p. 1946, Contribuição a genese dos magmas teleiticos: Minas Gerais Inst. Tecnologia Indus., Bol. 1, 69 p.

—_ 1951, Arqui-Brasil e sua evolução geológica: Brasil Div. Fomento Produção Mineral, Bol. 88, 314 p.

- 1953, Notas à Margem da Critica: Minas Gerais Inst. Tecnologia Indus. Avulso 16, $39 \mathrm{p}$.

-1958, Geologia estratigráfica e ecônomica do Brasil: Belo Horizonte, Estab. Gráficos Sta. Maria, 450 p.

Guimarães, Djalma, and Barbosa, Octávio, 1934, Mapa geológico do Estado de Minas Geraes: Minas Geraes Dept. Serviços Geog. Geol., Bol. 3, Annexo. Scale 1:1,000,000.

Harder, E. C., 1914, The "itabirite" iron ores of Brazil: Econ. Geology, v. 9, p. 101-111.

Harder, E. C., and Chamberlin, R. T., 1915, The geology of central Minas Geraes, Brazil: Jour. Gəology, v. 23, p. 341-424.

Herz, Norman, and Dutra, C. V., 1958, Preliminary spectrochemical and age determination results on some granitic rocks of the Quadrilátero Ferrífero, Minas Gerais, Brazil: Soc. Brasileira Geologia Bol., v. 7, no. 2, p. 81-95.

1960, Minor element abundance in a part of the Brazilian shield: Geochim. et Cosmochim. Acta, v. 21, p. 81-98.

Herz, Norman, Hurley, P. M., Pinson, W. H., and Fairbairn, H. W., 1961, Age measurements from a part of the Brazilian shield: Geol. Soc. America Bull., v. 72, no. 7, p. 1111-1120.

James, H. L., 1955, Zones of regional metamorphism in the Precambrian of northern Michigan: Geol. Soc. America Bull., v. 66 , no. 12 , pt. 1 , p. $1455-1488$.

Johnson R. F., 1962, Geology and ore deposits of the Cachoeira do Campo, Dom Bosco, and Ouro Branco quadrangles, Minas Gerais, Brazil: U.S. Geol. Survey Prof. Paper 341-B, 39 p.

Leith, C. K., 1917, Iron ores of the Americas: Pan American Sci. Cong., 2d, Washington 1917, Proc. sec. 7, v. 8, p. 954-959.

Leith, C. K., and Harder, E. C., 1911, Hematite ores of Brazil and a comparison with hematite ores of Lake Superior: Econ. Geology, v. 6, p. 670-686.

Moraes, L. J. de, and Barbosa, Octavio, 1939, Ouro no centro de Minas Gerais: Brasil, Div. Fomento Produção Mineral, Bol. 38, $186 \mathrm{p}$.

Moraes, L. J., Dorr, J. V. N., 2d, Guild, P. W., Barbosa, A. L. M., Iglesias, Dolores, and Meneghezzi, M. L., 1953, Jazidas de ferro do Brasil: Brasil Div. Geologia e Mineralogia, Bol. 144, $66 \mathrm{p}$.

Pimentel de Godoy, Manoel, 1957, Expressão Econômica do Vale do Paraopeba: Minas Gerais Dept. Aguas e Energia Electrica, 149 p.

Pomerene, J. B., 1958a, The Cercadinho Formation: Soc. Brasileira Geologia Bol., v. 7, no. 2, p. 64-65. 
1958b, Barreiro Formation: Soc. Brasileira Geologia Bol., v. 7, no. 2, p. 67-68.

1964, Geology and ore deposits of the Belo Horizonte, Ibirité and Macacos quadrangles, Minas Gerais, Brazil: U.S. Geol. Survey Prof. Paper 341-D, 84 p.

Ramberg, Hans, 1952, The origin of metamorphic and metasomatic rocks: Chicago, Univ. Chicago Press, 317 p.

Reeves, R. G., 1966, Geology and mineral resources of the Monlavade and Rio Piracicaba quadrangles, Minas Gerais, Brazil: U.S. Geol. Survey Prof. Paper 341-E, 58 p.

Rynearson, G. A., Pomerene, J. B., and Dorr, J. V. N., 2d, 1954, Contacto basal da Série de Minas na parte ocidental do Quadrilátero Ferrífero, Minas Gerais, Brasil: Brasil Div. Geologia e Mineralogia, Avulso 34, 18 p.
Simmons, G. C., 1958, The Fêcho do Funil Formation: Soc. Brasileira Geologia Bol., v. 7, no. 2, p. 65-66.

- 1963, Canga caves of the Quadrilatero Ferrífero, Minas Gerais, Brazil: Natl. Speleological Soc. Bull., v. 25, pt. 2, p. 66-72.

Teixeira da Costa, Manoel, 1961, Sedimentação e Orogênese da Série de Minas: Soc. Intercâmbio Cultural e Estudos Geol., pub. no. 1, p. 55-61.

Wallace, R. M., 1958, The Moeda Formation: Soc. Brasileira Geologia Bol., v. 7, no. 2, p. 59-60.

1965, Geology and mineral resources of the Pico de Itabirito district, Minas Gerais, Brazil: U.S. Geol. Survey Prof. Paper 341-F, 68 p. 



\section{INDEX}

[Italic page numbers indicate major references]

$\mathbf{A}$

Accessibility of report area

Acknowledgments. .

Age divisions, granitic rocks

Agriculture

Alberto Flôres, loading station

Alberto Flôres uplands.

Alluvial hematite

Alluvial iron

Alluvial iron reserves

Alluvial ores.

Alluvium

Altino Andrade iron deposit...................

Aluminum.

Amphibole.

B

Bação gneiss dome
Barbosa, A. L. M., and Dorr, J. V. N., 2d, quoted

Barreiro Formation . ........... 16, 17, 20

measured section.

Barreiro Formation and Sabará Formation, contact relationship ..............

Barretro Formation and Taboões Quartzite, contact relationship..............

Batatal Formation

measured section................................

Batatal Formation and Itabira Group, contact relationship

Batatal Formation and Moeda Formation, contact relationship..............

Bauxite

Beto Horizonte. municipio

Betím,

Bocaina iron deposits

Bocaina quarry

Bocaina quarry prospect

Bonfim gneiss dome

Brazilian Central Railroad

Brumadinho. municipio...

Brumadinho area. iron deposits.

Brumadinho hills

Brumadinho quadrangle

C

Cachoeira do Camp Granite

Candú area, iron deposits.

Candú deposit.............. 7, 28, 31

Candú mine, iron . . . . .

Canga..... 7, 22, 34, 37, 38, 40, 42, 43, 45, 46, 47, 48, 50, 51

Canga reserves ...... 35,36

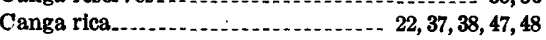

Caraça Group.......................... 6, 7,9,11,15

Carbonaceous material................. 9, 13, 20

Carbonate facies iron-formation............... 11

Catas Altas quadrangle.

27

20

28

14

11

11

2

3

2

Page
3
5
23
2
4
4
38
7
36
37
22
45
6
15
24

20

13

42

51

27

3,4

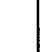

Cau@ Itabirite........... 13, 14, 28, 31, 34, 37, 38, 42, 46 chemical analyses...................... 15 Cenozoic deposits............... 22

Cercadinho Formation............ 16,17, 19, 30,45

measured section.

Cercadinho Formation and Focho do Funil Formation, contact relationship..

Cercadinho Formation and Itabira Group, contact relationship.............. 14,17

Cercadinho Formation and Sabará Formation, contact relationship...............

Chapinha. ................................. 15

Chemical analyses, Caus Itabirite............ Córrego do Feijão iron deposits............ iron ores, western Serra do Curral........ 41 stratified rocks.......... 12 Chlorite................ 9, 10,11, 13

Classifications, fron ore

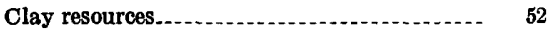

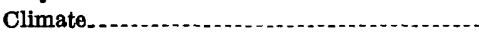

Colluvium........................ 22

Cómercio e Exploração de Minérios, Ltda..... 48

Compact hematite.......................... $31,34,37,38,42,43,45,46,47,48,50$ Companhia de Mineração Ferro e Carvão, S.A. Companhia Mineira de Siderurgia . ......... 31 Conceição do Rio Acima quadrangle_......... 28

Conglomerate . . ........................ 11, 17, 21

Congonhas, iron mines.................. 6

Congonhas district. . . . . . .

Contact relationship, Barreiro Formation and Sabarâ Formation ........... 20, 21

Barreiro Formation and Taboões Quartzite

Batatal Formation and Itabira Group.... Batatal Formation and Moeda Formation. Caue Itabirite and Gandarela Formation.

Cercadinho Formation and Fecho do Funil Formation..................

Cercadinho Formation and Itabira Group............................... 14, 17

Cercadinho Formation and Sabará Formation.

Fecho do Funil Formation and Cercadinho Formation..........................

Fecho do Funil Formation and Taboões Quartzite....................... 19, 20

Itabira Group and Batatal Formation....

Itabira Group and Cercadinho Formatíon....................... 14, 17

Itabirito(?) Gneiss and Souza Noschese Gneiss...

Minas Series and Nova Lima Group.....

Moeda Formation and Batatal Formation.

Moeda Formation and Souza Noschese Gneiss.......................... 11, 6

Nova Lima Group and Minas Series..... 9

Sabará Formation and Barreiro Formation................ 20, 21
Page

Sabará Formation and Cercadinho Formation.................... 21

Sabará Formation and Taboões Quartzite_ 21

Souza Noschese Gneiss and Itabirito(?) Gneiss............................ 25

Souza Noschese Gneiss and Moeda Formation.................................. 11,26

Taboöes Quartzite and Barreiro Forma-

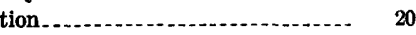

Taboões Quartzite and Fecho do Funil Formation........................ 19,20

Taboões Quartzite and Sabará Formation. $\quad 21$

Córrego do Feijão. .

Córrego do Feijão iron deposit..... $7,28,31,32,34,37$

chemical analyses........................ 40

ore reserves.......................... 40

Correlation, granitic rocks

Cross-range folds. ................ 28, 38, 42, 46

Crossbedding

Cummingtonite.

D

Dense hematite.............. 31, 47

Detrital deposits....... \$4

Diabase........ 6

Dikes......................... 26

Disconformities, Minas Series.............. 7

Dolomite_.......................... 13, 14, 16, 18, 18, 30

Dolomitic itabirite. . . . . . .

Don Bosco quadrangle. . . . ............. 28

Domes, gneiss....... 6, 23, 27

Dorr, J. V. N., 2d, and Barbosa, A. L. M., quoted............ 15

Drainage

E

Empresesa de Mineração Esperança, Ltda . . . 31,46

Engenheiro Correa Granodiorite. . ............ 23,27

Enriched itabirite_................... 22, 34, 47, 50

Esperança mine, iron.................... 32, 46,47

Estrada de Ferro Central do Brasil............

F

Faults, Piedade syncline.................. 29

Fazenda Brumadinho property............. $\quad 50$

Fazenda Rosário . . . . .

Fecho do Funil............... 3,4

Fecho do Funil Formation . . . . $7,16,17,18,30$ measured section

Facho do Funil Formation and Cercadinho Formation, contact relationship.. $\quad 17$

Fecho do Funil Formation and Taboões

Quartzite, contact relationship _. . 19, 20

Fêcho do Funil quadrangle................ 2

Folds, cross-range................... $28,42,46$

Nova Lima Group.

G

Gandarela Formation $\ldots \ldots \ldots \ldots \ldots . . . . .7,13,14,16,45$

Gandarela syncline......................... 28

Garnet. 


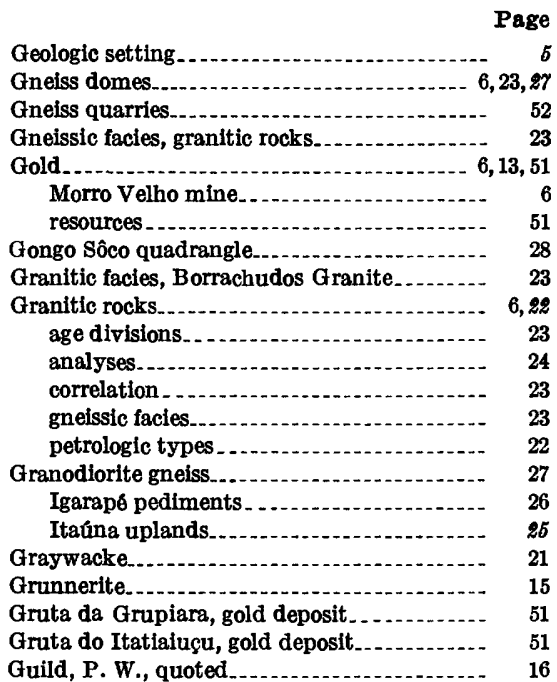

\section{$\mathrm{H}$}

Hard itabirite 15 $10,11,14,15,17,19,31$ alluvial.......... 38 compact........... 7 7, dense.............. laminated....... 32,47 reserves.......................... 35,36 soft............... 7, 31, 32, 37, 38, 42, 43, 46, 47, 48

Hematite schist ................................

Ibirité quadrangle.................. 27, 28, 31 Icominas, S. A., mining company .......... 31, 43 Igarape...

Igarapé pediments granodiorite gneiss.

Igarapé quadrangle..

(1,4

Inhotim mine . . .

alluvial

Iron deposits.

Altino Andrade.

Bocaina.............. 42

Brumadinho area . ...................... 37

Candú. ........................... 28, 31

Candú area.

Córrego do Feijão _.......... . 28, 31, 32, 34, 37

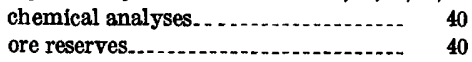

Laranjeiras.

Pau de Vinho . . . .

Pico dos Tres Irmãos. ........................

Serra da Mantiqueira-Serra do Barreiro.

Serra das Farofas.

Serra do Itatiaia

Serra Fecho do Funil canga deposits..... Serrađão.

Souza Noschese.

Tijuco canga deposit.

Tijuco rolado deposit.

West End area. carbonate facies. . ................ 11 oxide facies..

Iron mines, Candú mine........... 16, 35, 46, 47, 48 Congonhas................................... 6 Esperança mine. Itabira . Saraiva mine.............................. $31,47,48$

Iron ore, alluvial.
chemical analyses. chemical analyses... . .

potential...

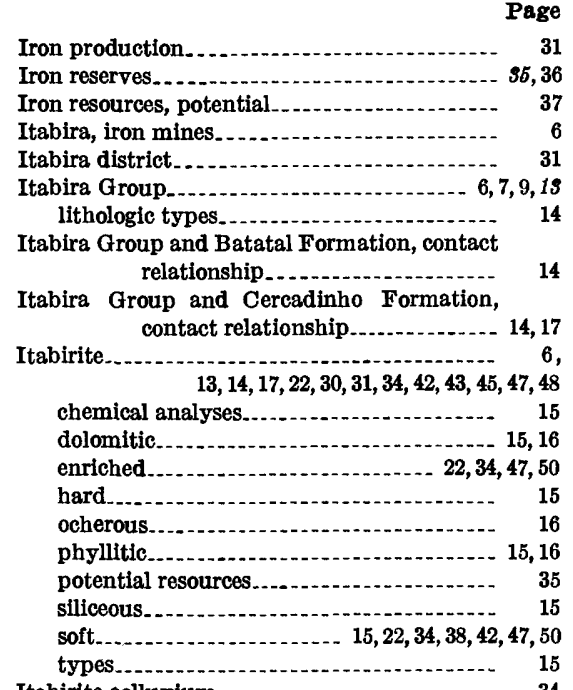
Itabirite colluvium.

Itabirite reserves... ........... 36

Itabirito(?) Gneiss
Itabirito(?) Gneiss and Souza Noschese Gneiss, Itabirito(?) Gneiss and Souza Noschese Gneiss,
contact relationship........ 23,27

Itabirito Granite.

Itacolumi Series.

Itaguá.

Itatiaia hills

Itatiaiucu.

Itatialuçu Cave, gold deposit...... 51

Itatiaiuçu quadrangle.

Itaúna................... 3

municipio..

Itaúna uplands.

granodiorite gneiss.

\section{$\mathbf{J}, \mathbf{K}$}

J. Rabelo, S. A., mining company 31

Kupferite. . .

\section{$\mathbf{L}$}

Laminated hematite...

Laranjeiras imon deposit

Laterite.

Limonite

Literature cited

Lithologic types, Itabira Group.

Location of report area.......... 2

Macacos quadrangle $\mathbf{M}$

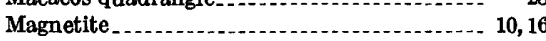

Manganese .................................. 6,13

Manganese deposits, Manoel Sampaio prospect....

Serra Azul prospects

51

Manoel Sampaio prospect, manganese. . ......- 51

Marker beds, Nova Lima Group. 10

Mateus Leme, municiplo

Measured section, Barreiro Formation.......

Batatal Formation......................

Cercadinho Formation

Fecho do Funil Formation.

Moeda Formation.

Metadiabase..

Metamorphism.

contact.

regional.

Metasedimentary rocks

Minas de Ferro, S. A . . . . . . . . . 31,46

Minas do Paraopeba, S. A.

Minas Series............................ 4,6,7,11

Minas Series and Nova Lima Group, contact relationship. ........................
Page

Mine workings, Bocalna iron deposits. ....... $\quad 42$ Candú area..................... 47

Córrego do Feijão iron deposits......... 38

Pau de Vinho iron deposit.......... $\quad 50$

Serra Azul .

Serra da Mantiqueira-Sierra do Barreiro-- $\quad 50$

Serradão deposit

Mineração Geral do Brasil ............. 31, 46

Mineral do Brasil, Ltda

Mixed rocks, petrologic type................. 23

Moeda Formation ............... 11,28, 30 measured section.

Moeda Formation and Batatal Formation, contact relationship ...............

Moeda Formation and Souza Noschese Gneiss, contact relationship............ 11, 26

Monlevade district.

28

Morro Velho mine, gold. . . . . . . . . 6

\section{$\mathbf{N}$}

Northern gneiss dome

Nova Lima Group -

folds. -

marker beds.

Nova Lima Group and Minas Series, contact relationship............................

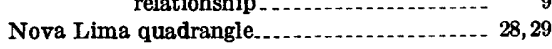

\section{O}

Ocherous itabirite

Opaque mineral

Ore deposits.

Ore production, Altino Andrade deposit

Bocaina iron deposits......................

Candú area. .

Pau de Vinho iron deposit. . . . . . . . . . . .

Serra da Mantiqueira-Serra do Barreiro .

Serra do Itatiaia

Serradão iron deposit.

Tijuco rolado deposit

Ore reserves, Bocaina iron deposits........... Candú area.

Córrego do Feijão iron deposits

Laranjeiras iron deposit................. 42

Pau de Vinho iron deposit.............. 50

Pico dos Tres Irmãos íron deposits.......

Serra Azul.

Serra de Mantiqueira-Serra do Barreiro...

Serra da Itatiaia.-

Serradão iron deposit

Souza Noschese iron deposits.

Tijuco canga deposit..

Tijuco rolado deposit.

Tico compounds, Batatal Formatic

ormation

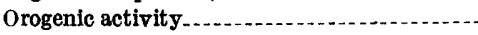

Oxide facies iron-formation .................... 11

Pardo Lopes quarry

quarry

Pau de Vinho iron deposit.

Pelitic rocks..... 30

Petrologic types, granitic rock $9,11,13,14,16,17,18,19,20,21,27$

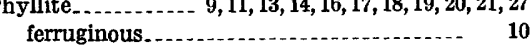

Phyllitic itabirite

Physiographic divisions. ...................... 4

Pico de Itatiaiuçu.............. 4

Pico dos Tres Irmãos.

iron deposits. .............................. 42

Piedade do Paraopeba quadrangle............ 23

Piedade quadrangle. . . .

Piedade syncline.

north limb

Piracicaba Group.... 6, 7,9,16

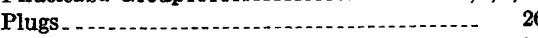

Pomerene, J. B., quoted................... 21

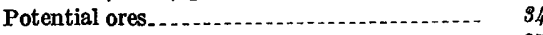

$\begin{array}{ll}\text { Potential resources, iron } & \mathbf{3 7} \\ \quad \text { itabirite } & \mathbf{3 5}\end{array}$

recambrian rocks, stratigraphic column

Precambrian rocks, stratigraphic column.....
Previous investigations

11

6

7

27
10

9


Q

Page

Quartz.

Quartzite

$9,10,11,14,17,18,19$

Quilombo property.

43,45

$\mathbf{R}$

Recovery factor......................... 32, 34, 35

Rode Mineira de Viaçäo.

Replacement deposits

$$
\text { origin. }
$$

Residual deposits.

Resources, clay.

potential, iron itabirite.

Reverse faults.

Ribeirão Serra Azul

Ribeirão Vermelho

Rice grit.

Rio Acima quadrangle

Rio das Velhas Series

Rio de Janeiro.

Rio Pará...

(1)

Rio São João.

ort area.

Roads in report area..........................

Rolado_. 7, 22, 34, 37, 38, 40, 42, 43, 45, 46, 47, 48, 50, 51

Rolado reserves.

\section{S}

Sabará Formation.

$4,16,17,21,30$

Sabará Formation and Barreiro Formation,

contact relationship 35, 36

\begin{tabular}{rr}
\hline$, 34,35$ \\
4 \\
81 \\
33 \\
54 \\
52 \\
37 \\
35 \\
29 \\
4 \\
4 \\
17 \\
28 \\
\hline $6,7,9$ \\
4 \\
5 \\
4,5 \\
$-\quad 5$ \\
5 \\
\hline 4 \\
\hline 3 \\
\hline 50,51 \\
\hline 35,36
\end{tabular}

Sabará Formation and Cercadinho Formation, contact relationship

Sabará Formation and Taboōes Quartzite, contact relationship.

Santa Luzia quadrangle.

Saprolite

Schist.

$-9,10,11,21$

Sericite

Serra Azul

Serra Azul prospects, manganese

Serra Azul quadrangle....................... 2

Serra das Farofas

iron deposits.

Serra das Queias.............................. 4,27

Serra do Curral. . . . .

Serra do Gentio.

Serra Fecho do Funil canga deposits.......... 45

Serradão iron deposit........................ 40

Siliceous itabirite . .................. 15

Sills

Siltstone........................................... 18,19

Smelting facilities, West End area......... 3

Socomine concession ........................ 43

Soft hematite........... 7, 31, 32, 37, 38, 42, 43, 46, 47, 48

Soft itabirite . ................. 15, 22, 34, 38, 42, 47, 50

Sousas...............................................

Sousas quadrangle.......................... 2,9

Souza Noschese..................... $\quad \mathbf{3 , 4}$

Souza Noschese Gneiss........... 4, 6, 7, 23, 25, 27, 30

Souza Noschese Gneiss and Itabirito(?) Gneiss, contact relationship....... 25

Souza Noschese Gneiss and Moeda Formation, contact relationship.

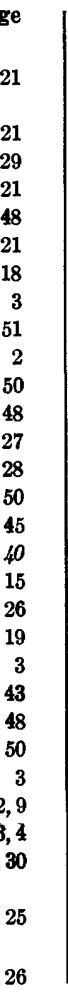

Page

Souza Noschese iron deposits................ 45 Splash rock Stahlunion. .................... 31, 38

Staurolite.................................... 31

Stratified rocks, chemical analyses...... 12

Stratigraphic divisions................ 7

Structural features.................. 6,27

Structure canga.

$\mathbf{T}$

Taboões Quartzite........................ 16, 17, measured section. ...................... 20

Taboões Quartzite and Barreiro Formation,

contact relationship...............- 20

Taboões Quartzite and Fecho do Funil Formation, contact relationship.......... 19, 20

Taboões Quartzite and Sabará Formation, contact relationship............... 21

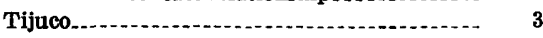

Tijuco canga deposit......................... 43

Tijuco rolado deposit............... 7, 34, 43

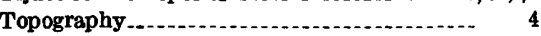

Towns in report area......................... 3

Tremolite..................................... 15

Tremolitic itabirite.

Tres Irmฉ̃os property

Tres Pontes property ....................... 50

$\mathrm{V}, \mathrm{W}$

Valley fill.

Vegetation.

Volcanic agglomerate.......... 21

West End area, definition........................... 2

iron deposits 


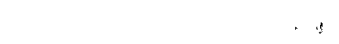



